\title{
ABSORÇÃO DE MACRONUTRIENTES PELAS CULTIVARES DE VIDEIRA THOMPSON SEEDLESS E ITALIA SOB EFEITO DE DIFERENTES RETARDADORES DE CRESCIMENTO E PORTA-ENXERTOS
}

TERESINHA COSTA SILVEIRA DE ALBUQUERQUE Engenheira Agrônoma

Orientador: Prof. Dr. ANTONIO ROQUE DECHEN

Tese apresentada à Escola Superior de Agricultura "Luiz de Queiroz", Universidade de São Paulo, para obtenção do título de Doutor em Agronomia, Área de Concentração: Solos e Nutrição de Plantas.

\author{
PIRACICABA \\ Estado de São Paulo - Brasil \\ Janeiro - 1998
}


Dados Internacionais de Catalogação na Publicação (CIP) DIVISÃO DE BIBLIOTECA E DOCUMENTAÇÃO - Campus "Luiz de Queiroz"/USP

Albuquerque, Teresinha Costa Silveira de Absorção de macronutrientes pelas cultivares de videira Thompson Seedless e Itaiia sob efeito de diferentes retardadores de crescimento e porta-enxertos / Teresinha Costa Silveira de Albuquerque. - Piracicaba, 1998.

$69 \mathrm{p}$. : il.

Tese (doutorado) - - Escola Superior de Agricultura Luiz de Queiroz, 1998. Bibliografia.

1. Clima tropical 2. Inibidor de crescimento 3. Macronutriente 4. Planta cultivada 5. Porta-enxerto 6. Regulador de crescimento 7. Uva I. Título 


\section{ABSORÇÃO DE MACRONUTRIENTES PELAS CULTIVARES DE VIDEIRA THOMPSON SEEDLESS E ITALIA SOB EFEITO DE DIFERENTES RETARDADORES DE CRESCIMENTO E PORTA-ENXERTOS}

TERESINHA COSTA SILVEIRA DE ALBUQUERQUE

Aprovada em: 26.03.1998

Comissão julgadora:

Prof. Dr. Antonio Roque Dechen ESALQ/USP

Prof. Dr. Paulo Roberto de Camargo e Castro ESALQ/USP

Dr. Maurilo Monteiro Terra $\mathrm{IAC} / \mathrm{SP}$

Prof. Dr. Fernando Mendes Pereira UNESP/Jaboticabal Prof. Dr. Ede Cereda UNESP/Botucatu

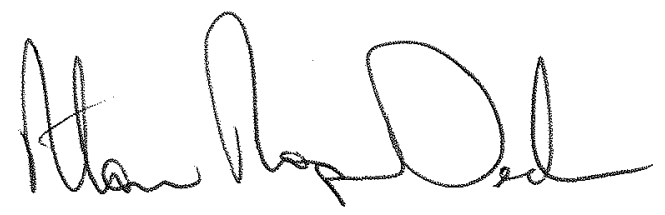

Prof. Dr. ANTONIO ROQUE DECHEN Orientador 


\section{A TERra É NOSSA MÃE}

Cacique Seattle, 1855 Estados Unidos da América

Nós somos parte da terra e a terra é parte de nós. As flores perfumadas são nossas irmãs; Os rios são nossos irmãos; O búfalo, o cavalo e a grande águia são nossos irmãos; As cristas rochosas, os ursos das campinas e o homem, Todos pertencemos a mesma familia. Esta água brilhante que corre nos rios e regatos Não é apenas água, é o sangue dos nossos antepassados; O rumorejar da água é a voz do pai do meu pai; Cada reflexo na água limpida dos lagos Conta o evento da vida do meu povo.

Sabemos que o homem branco não compreende o nosso modo de viver, Para ele um pedaço de terra é igual a outro.

Porque ele é um forasteiro que chega na calada da noite. Ele trata sua mãe terra e seu irmão céu como coisas Que podem ser compradas, saqueadas e vendidas.

Sua voracidade arruinará a terra, deixando para trás apenas o deserto. De uma coisa sabemos: a terra não pertence ao homem, É o homem que pertence a terra, e disso temos certeza. Todas as coisas estāo interligadas como o sangue que une uma família. Não foi o homem que teceu a trama da vida, Ele é simplesmente o fio dessa trama.

E tudo que o homem fizer a ela A si próprio estará fazendo. Ensina a teus filhos o que temos ensinados aos nossos: A terra é nossa mãe e tudo quanto fere a terra Fere os filhos da terra. 
Aos meus amados filhos,

que são a razão do meu viver,

Inessa, Antero, Leandro e Irena,

pelos quais tenho procurado sempre

crescer profissionalmente, mostrando-lhes

que o caminho do saber é árduo, porém não impossivel.

Dedico

Aos meus queridos pais Anarolino Silveira Filho (em memória) e Ruth Costa Silveira, que nunca mediram esforços para educar os filhos, abrindo-nos sempre o caminho para o conhecimento e a sabedoria.

Ofereço 


\section{AGRADECIMENTOS}

A Deus por amparar-me nos momentos dificeis, por carregar-me no colo nos momentos impossiveis e por continuar sempre a olhar por mim como uma das suas mais queridas filhas.

À Empresa Brasileira de Pesquisa Agropecuária e em especial aos dirigentes do Centro de Pesquisa Agropecuária do Trópico Semi-Árido, pela oportunidade de realização do curso.

À Escola Superior de Agricultura “Luiz de Queiroz” por terme em seu corpo discente.

Ao Prof. Dr. Antonio Roque Dechen pela orientação e confiança em mim depositada.

Ao Prof. Dr. Francisco Antonio Monteiro pelo apoio como coordenador do Curso de Pós-Graduação em Solos e Nutrição de Plantas.

Ao Prof. Dr. Quirino Augusto de Camargo Carmello pelo apoio no desenvolvimento dos trabalhos na casa-de-vegetação.

Ao Prof. Dr. Paulo Roberto de Camargo e Castro e aos funcionários do Laboratório de Fisiologia Vegetal pela atençāo e apoio estrutural no desenvolvimento de uma das pesquisas que compõe esta tese.

Ao meu querido mestre Júlio Seabra Inglez de Sousa, pelos ensinamentos transmitidos em nossas conversas sobre as videiras.

A todos os funcionários do Laboratório de Nutrição Mineral de Plantas, Sueli M. A. C. Bovi, Mirtes V. Sesso, Edinéia C. S. Mandoni, Lúcia H. S. P. Forti, Alexandre e em especial a Lurdes A. D. de González e 
Nivanda M. de Moura pela presteza em orientar-me na realização das análises.

Aos professores da ESALQ e do CENA pelos conhecimentos transmitidos e que direta ou indiretamente contribuiram para a minha formação científica.

Aos colegas de curso (particularmente aos da salinha de pós-graduação de nutrição mineral de plantas), que no decorrer destes anos tornaram-se, além de amigos, companheiros inesqueciveis, com os quais pudemos rir e chorar e agradecer a Deus por estarmos juntos.

MUITO OBRIGADA! 


\section{SUMÁRIO}

Página

RESUMO ...................................................................................

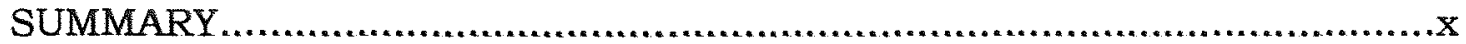

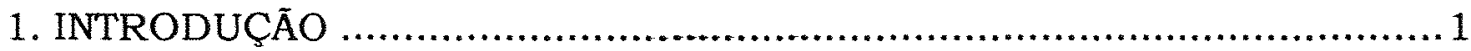

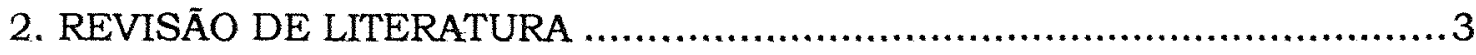

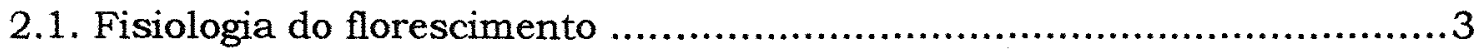

2.1.1. Aspectos hormonais do florescimento ..................................... 3

2.1.2. Fatores ambientais no florescimento ................................... 5

2.2. Práticas culturais e o vigor das plantas......................................8

3. EFEITO DE RETARDADORES DE CRESCIMENTO NAS

CARACTERISTICAS NUTRICIONAIS DAS CULTIVARES DE VIDEIRA

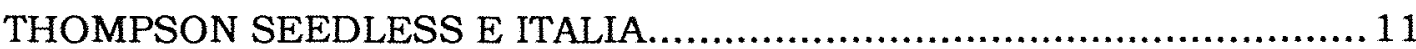

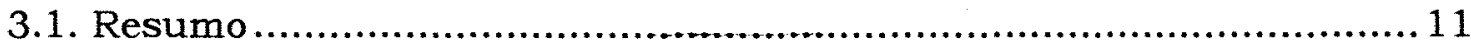

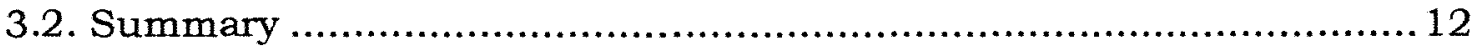

3.3. Introdução................................................................... 12

3.4. Material e Métodos............................................................ 14

3.4.1. Localização do experimento ............................................ 14

3.4.2. Delineamento experimental ........................................ 14

3.4.3. Cultivares utilizadas .................................................. 15

3.4.4. Condução do experimento .............................................. 17

3.5. Resultados ..................................................................... 19

3.5.1. Curva de crescimento das plantas .................................... 19

3.5.2. Diferença entre comprimento final e inicial dos ramos (CF-CI) e massa

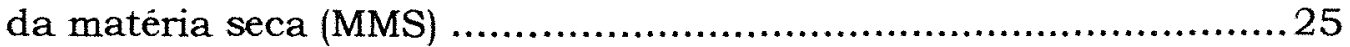

3.5.3. Teor e quantidade acumulada de nutrientes nos ramos................26

3.5.4. Teor e quantidade acumulada de nutrientes nos peciolos ..............29

3.5.5. Produção de paniculas florais ........................................... 32

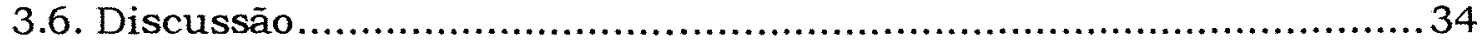

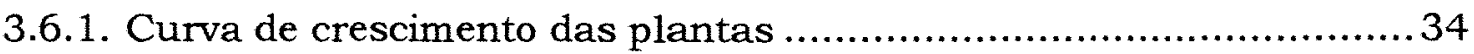

3.6.2. Diferença entre comprimento final e inicial dos ramos (CF-CI) e massa da matëria seca (MMS) ................................................ 34 
3.6.3. Teor e quantidade acumulada de nutrientes nos ramos ................ 35

3.6.4. Teor e quantidade acumulada de nutrientes nos peciolos ...............36

3.6.5. Produção de paniculas florais ........................................ 37

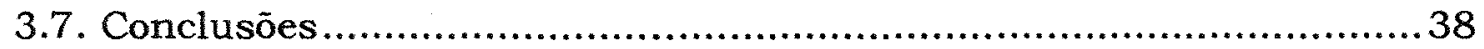

4. ABSORÇĀO DE MACRONUTRIENTES POR SEIS PORTA-ENXERTOS E

DUAS CULTIVARES DE VIDEIRA EM CONDIÇÕES DE HIDROPONIA....39

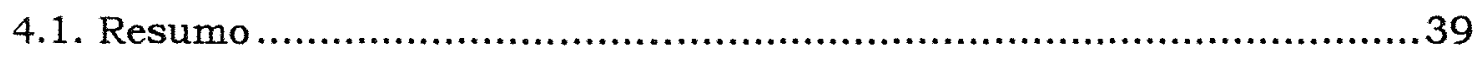

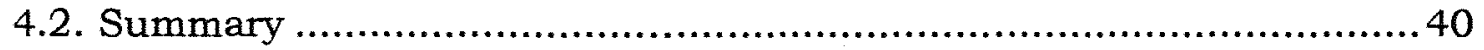

4.3. Introdução............................................................. 40

4.4. Material e métodos............................................................ 42

4.4.1. Localização do experimento .............................................42

4.4.2. Delineamento experimental ........................................ 42

4.4.3. Cultivares utilizadas .................................................... 43

4.4.4. Condução do experimento ...........................................52

4.4.5. Variáveis analisadas ................................................... 54

4.4.6. Análise estatistica ...................................................... 54

4.5. Resultados e discussão ............................................. 54

4.5.1. Produção de matéria seca........................................................54

4.5.2. Quantidade acumulada de macronutrientes..........................56

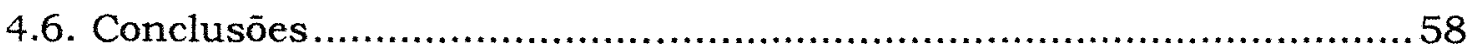

5. CONSIDERAÇÕES FINAIS.......................................................60

6. CONCLUSÕES................................................................... 62

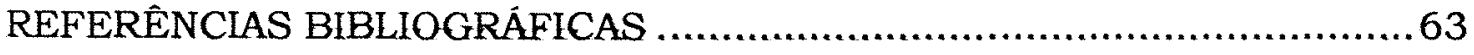




\title{
ABSORÇÃO DE MACRONUTRIENTES PELAS CULTIVARES \\ DE VIDEIRA THOMPSON SEEDLESS E ITALIA SOB EFEITO DE DIFERENTES RETARDADORES DE CRESCIMENTO E PORTA-ENXERTOS
}

\author{
Autora: TERESINHA COSTA SILVEIRA DE ALBUQUERQUE \\ Orientador: Prof. Dr. ANTONIO ROQUE DECHEN
}

\section{RESUMO}

Com o objetivo de avaliar a variação no teor de macronutrientes como resposta ao uso de retardadores de crescimento em plantas das cultivares 'Thompson Seedless e Italia e detectar a capacidade de absorção de macronutrientes em alguns porta-enxertos de possivel utilização para a cultivar 'Thompson Seedless', realizaram-se dois experimentos, que foram desenvolvidos em casa-de-vegetaçāo. Testou-se, no primeiro experimento um controle e quatro retardadores de crescimento: chlormequat $-1.500 \mathrm{mg}$ p.a. $\mathrm{L}^{-1}$; daminozide - 3.000mg p.a. $\mathrm{L}^{-1}$; uniconazole - 30mg p.a.L-1; cloreto de mepiquat

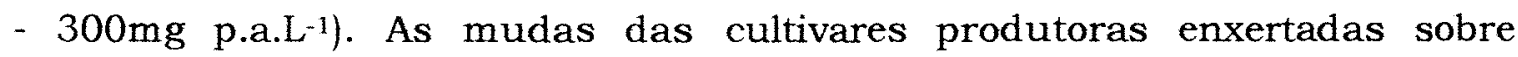
'Tropical' foram transplantadas para vasos com 35L de uma mistura 1:1:1 em volume de areia, de solo e de composto orgānico. A cada 150 dias realizava-se a poda deixando-se duas varas de seis gemas. A irrigação foi por gotejamento, colocando-se em cada vaso um litro de água por dia. As videiras foram adubadas com um litro de composto orgânico e com uma solução de micronutrientes e com adubos quimicos $(1,45 \mathrm{~g}$ de MAP, 3,42g de nitrato de cálcio, 1,61g de uréia, $3,53 \mathrm{~g}$ de cloreto de potássio e $1,94 \mathrm{~g}$ de sulfato de magnésio) a cada 15 dias durante os ciclos vegetativos. No segundo experimento os porta-enxertos Tropical - IAC 313, Jales - IAC 572, Campinas IAC 766, Dog Ridge, Salt Creek e Harmony e as produtoras: Italia e Thompson Seedless foram propagados por estacas de 2 gemas, colocadas para enraizar 
em areia grossa. Após o crescimento das raizes as mudas foram transplantadas para recipientes de $3 \mathrm{~L}$ de volume, com uma mistura $2: 1$ de silica e areia grossa. Nessa ocasião as mudas foram uniformizadas através de poda, tanto do sistema radicular como da parte aérea. A solução nutritiva foi preparada segundo Furlani (1995), sendo aplicada por irrigação em sistema fechado de gotejamento, acionado por temporizador. Quando as plantas apresentavam um ou dois ramo com $1,50 \mathrm{~m}$ aproximadamente, foi realizada a poda do sistema aéreo. Por ocasião da poda coletou-se no primeiro experimento os peciolos das folhas e os ramos e no segundo, os ramos juntamente com as folhas. Os materiais de ambos foram postos em estufa para secagem e a seguir, foram pesados para determinação da massa de matéria seca. O material seco resultante foi moido e as amostras obtidas foram analisadas quanto ao teor de macronutrientes conforme metodologia descrita em Sarruge e Haag (1974). A análise estatistica através do programa SAS dos resultados obtidos permitiu concluir no primeiro experimento que é possivel não só diminuir o ritmo de crescimento dos ramos, como também alterar a concentração de nutrientes em plantas de videira das cultivares Thompson Seedless e Italia pelo uso de retardadores de crescimento, favorecendo a formação de gemas férteis; e no segundo, constatou-se que os porta enxertos Jales e Tropical são os mais vigorosos; a quantidade de macronutrientes acumulados é proporcional a produção de biomassa das plantas; as cultivares Thompson Seedless e Italia apresentam capacidade de absorção de macronutrientes semelhante a dos porta-enxertos de baixos e médio vigor. 


\section{GROWTH REGULATORS AND ROOTSTOCKS EFFECTS ON MACRONUTRIENTS UPTAKE IN THOMPSON SEEDLESS AND ITALIA GRAPEVINES}

Author: TERESINHA COSTA SILVEIRA DE ALBUQUERQUE Adviser: Prof. Dr. ANTONIO ROQUE DECHEN

\section{SUMMARY}

Two experiments were carried out in a greenhouse to evaluate the variation in the macronutrients contents in relation of growth regulators sprays on Thompson Seedless e Italia grapevines and the macronutrients uptake capacity of some rootstocks to Thompson Seedless cv. with the best correlations. In the first, treatments comprised: chlormequat-1.500mg. $\mathrm{L}^{-1} ; \quad$ daminozide-3.000mg. $\mathrm{L}^{-1}$; uniconazole-30mg. $\mathrm{L}^{-1}$; mepiquat chloride-300mg. $\mathrm{L}^{-1}$ and control. The cuttings were grafted on Tropical rootstock and were rooted in sand. After 105 days of growth they were transplanted to $35 \mathrm{~L}$ pots with a mixing of 1:1:1 volume of sand, soil and organic matter. Grapevines were pruned each 150 days, left two canes with six buds each one. Water was supplied through drop irrigation system $(1 \mathrm{~L} /$ plant day). Grapevines were fertilized with $1 \mathrm{~L}$ of manure and micronutrients solution at each pruning. Macronutrients (MAP-1,45g, $\mathrm{Ca}_{2} \mathrm{NO}_{3}-3,42 \mathrm{~g}$, urea-1,61g de , $\mathrm{KCl}-3,53 \mathrm{~g}$ and $\mathrm{MgSO}_{4}-1,94 \mathrm{~g}$ ) were suplied each 15 days during the plants growth. In the second experiment, the rootstochs Tropical - IAC 313, Jales - IAC 572, Campinas - IAC 766, Dog Ridge, Salt Creek e Harmony; and Italia and Thompson Seedless cultivars was propagated from two buds cuttings in sand until roots development when the plants were transplanted into $3 \mathrm{~L}$ pots with a mixing 2:1 
volume of silica and sand. The young grapevines were pruned for homogeneous size. The growth solution was prepared according to Furlani (1995) supplied by a dropping system. The pruning was made when the grapevines shoots were $1,50 \mathrm{~m}$. The petioles and canes were sampled in the first experiment and the shoots only, in the second. The dry matter was evalueted for production and macronutrients contents (N, P, K, Ca and $\mathrm{Mg}$ ). Results had shown that: growth regulators spray induced alteration in the macronutrients patterns due to the decrease of shoots rate growth and increase fruitfull shoots. And, in the second, it was indicated that: Jales and Tropical rootstock were more vigorous than the others; the macronutrients uptaked was relative to the biomass production; Thompson Seedless and Italia grapevines biomass production were lesser than Jales rootstock; Thompson Seedless and Italia macronutrients uptake were such as weakly and midle vigour rootstock. 


\section{INTRODUÇÃO}

A produção de uvas finas de mesa para consumo "in natura", sob condições de irrigação, na região semi-árida do nordeste do Brasil está concentrada nas margens do Rio São Francisco, com uma área plantada em 1996 de 4.847 hectares (Anuário Estatístico do Brasil, 1996) e uma produtividade de 30 toneladas por hectare ao ano, o que significa um rendimento econômico médio na ordem de 80 milhões de dólares. Os plantios nessa região estão baseados praticamente em cultivares com sementes - 'Italia', 'Piratininga' e 'Red Globe'. A introdução de cultivares apirênicas (sem sementes) que pudessem ser facilmente comercializadas pela grande aceitação do mercado consumidor internacional e mesmo nacional, faria com que houvesse um maior impulso na produção viticola daquela região, resultando na maior mobilidade mercadológica do viticultor.

A cultivar sem sementes mais importante em nivel mundial para comercialização "in natura" é a Thompson Seedless, que apresenta, entretanto, uma adaptação climática limitada a poucas áreas no mundo (Califórnia nos Estados Unidos, região norte do Chile, Israel e algumas outras áreas da região mediterrânea) em função da necessidade de condições especiais de temperatura, intensidade luminosa, fotoperiodo e nutrição mineral para que o processo de diferenciação das gemas vegetativas se efetue em gemas mistas com primórdios de ramo e de panícula floral.

Em condiçōes de clima tropical essa cultivar apresenta-se excessivamente vigorosa, com uma vegetação muito intensa em detrimento do desenvolvimento de inflorescências, ficando a produção resumida a poucos e pequenos cachos, apresentando os mesmos peso inferior a $300 \mathrm{~g}$.

A insuficiente diferenciação das gemas latentes, que resulta na baixa fertilidade das mesmas é ainda mais acentuada quando a 'Thompson Seedless' 
é enxertada no porta-enxerto 'Tropical' (IAC 313), dando origem a plantas excessivamente vigorosas com ramos que crescem em torno de dez metros de comprimento num periodo de quatro meses.

Os porta-enxertos apresentam grande variação em vigor, em conseqüência das diferentes exigèncias nutricionais e capacidade de absorção de água e nutrientes, pois suas raizes apresentam uma seletividade na absorção de ions da solução do solo. A utilização de porta-enxertos em viticultura tem como objetivos melhorar não apenas o vigor das plantas enxertadas, como também a produção e qualidade dos frutos, alterando, em algumas cultivares, a época de maturação destes; e controlar a incidência de pragas de solo, tais como filoxera, nematóides e pérola-da-terra.

A compatibilidade ideal porta-enxerto e cultivar produtora deve tender à obtenção de vinhedos em que se realize a máxima utilização dos nutrientes da solução do solo, com a máxima eficiència fisiológica da parte aérea, havendo um perfeito equilibrio entre crescimento vegetativo e reprodutivo.

A diferenciaçāo e desenvolvimento dos primórdios florais são controlados por uma série de mudanças bioquimicas, desencadeando alterações em nivel hormonal e celular. A utilização de retardadores de crescimento, tais como: chlormequat, cloreto de mepiquat e hidrazida maleica, aplicados após a floração favorecem o desenvolvimento dos primórdios das inflorescências e causam o aumento na produção da cultura.

Pondera-se que, através do uso de porta-enxertos adaptados às condições tropicais e da aplicação de retardadores de crescimento, poder-se-ia favorecer a distribuição de nutrientes e o balanço hormonal em videiras da cultivar Thompson Seedless, obtendo-se, em conseqüència, plantas equilibradas sem grande crescimento vegetativo e com boa fertilidade de gemas. 


\section{REVISÃO DE LITERATURA}

\subsection{Fisiologia do florescimento}

O florescimento em videiras maduras é um processo fisiológico que tem início no ciclo anterior ao do aparecimento da panícula floral, quando da formação das gemas a medida que o ramo cresce. O processo de florescimento, descrito por Mullins (1986), começa com a formação de um primórdio não diferenciado, denominado de anlagen, originado nos ápices meristemáticos das gemas latentes que estão se formando. A partir do anlagen desenvolve-se ou o primórdio da inflorescência ou o primórdio da gavinha e a seguir as gemas latentes entram num processo de dormência. A formação final das flores ocorre por ocasiāo da brotação das gemas no ciclo seguinte. Estas etapas do desenvolvimento floral são mediadas por fitohormônios e podem ser afetadas não só por reguladores de crescimento, fatores ambientais e nutricionais, como também pela alteração do vigor das produtoras através do uso de portaenxertos mais ou menos vigorosos.

\subsubsection{Aspectos hormonais do florescimento}

\section{- Giberelinas}

Giberelinas estão envolvidas na formação e na determinação do desenvolvimento do anlagen. Quando Srinivasan e Mullins (1980) trataram videiras crescidas em vasos com ácido giberélico $\left(\mathrm{GA}_{3}, 3-30 \mu \mathrm{M}\right)$, ocorreu uma brotação prematura com crescimento das gemas latentes e a formação precoce dos primórdios não diferenciados, no segundo e terceiro nós, em vez de formar-se no quarto e quinto nós como é normal. No entanto o anlagen formado em plantas tratadas com $\mathrm{GA}_{3}$ deu origem somente a gavinhas, ficando 
inibida a formação de primórdios de inflorescência. A formação dos primórdios não diferenciados e o alongamento das gavinhas foi suprimido pelo uso de chlormequat, um inibidor da biossintese das giberelinas.

Chailakhyan (1977) revendo pesquisas realizadas nos últimos 40 anos sobre o controle hormonal no florescimento, propôs que as giberelinas estariam envolvidas no formação do eixo da inflorescência nas plantas. Em videiras este fato é fortemente sugerido pela inibição da formação do anlagen e a supressão do crescimento da gavinha pelo chlormequat, que age inibindo a biossintese de giberelinas. A ação das giberelinas no florescimento em videiras varia com o estádio de desenvolvimento da gema latente. $O$ ácido giberélico age como promotor do florescimento no inicio da formação do anlagen e como inibidor na etapa seguinte, quando induz o anlagen a formar gavinhas ao invês de inflorescências (Mullins et al., 1992).

\section{. Citocininas}

As citocininas estão envolvidas com o controle de muitos aspectos da reprodução da videira, entretanto o mecanismo pelo qual elas atuam é desconhecido, podendo, entretanto, estar associado com a partição de assimilados. Tem sido demonstrado em muitas plantas, inclusive Vitis vinifera, que as citocininas mobilizam, em grande intensidade, assimilados para o local de aplicação (Mullins et al., 1992), e vários autores têm sugerido que a regulação dos metabólitos está envolvida no florescimento (Sachs e Hackett, 1976; Sachs, 1977).

Os fatores ambientais (temperaturas elevadas, alta intensidade luminosa e niveis adequados de umidade e macronutrientes no solo) que favorecem o florescimento nas videiras são os mesmos que induzem a biossintese de citocininas, o que vem a confirmar a participação destas no florescimento (Srinivasan e Mullins, 1981).

Quando as gemas latentes entram em atividade, os primórdios das inflorescências que foram formadas no ciclo anterior passam por um rápido desenvolvimento, dando origem aos primórdios das flores. Durante a fase de brotação das gemas e no posterior florescimento, a seiva do xilema apresenta uma alta atividade de citocininas (Nitsch e Nitsch, 1965; Skene e Kerridge, 
1967), existindo ainda fortes evidências de que as citocininas produzidas nas raizes estariam envolvidas na regulação da diferenciação das flores (Mullins et al., 1992).

\section{- Retardadores de crescimento}

Alguns compostos quimicos conhecidos, genericamente, como retardadores de crescimento têm sido utilizados para promover o florescimento. Agem contrariamente à ação das giberelinas e ao crescimento dos ramos, tais como o cloreto de clorocolina ou chlormequat, o cloreto de mepiquat, o paclobutrazol e o uniconazole, que bloqueiam uma ou mais etapas da biossintese das giberelinas.

Motomura (1986) com o uso de daminozide, retardador que interfere na ação auxinica, conseguiu aumentar a percentagem de distribuição de assimilados para as inflorescências na cultivar Delaware pulverizado-o nos ramos, duas semanas antes da plena floração.

De acordo com vários autores (Coombe, 1967; Skene, 1970; Lilov e Andanova, 1976), o chlormequat induz alteraçōes nos padrões de crescimento e desenvolvimento das videiras em contraposição aos efeitos das giberelinas, alèm disso, favorece a formação de folhas verdes escuras e induz o florescimento, efeitos semelhantes aos obtidos com o uso de citocininas.

O chlormequat é também utilizado na videira em pulverizaçōes ou aplicaçōes localizadas, como citado por alguns autores (Pereira e Koshida, 1973; Coombe, 1970), antes da antesis para aumentar o número de bagos por cacho, resultando em cachos mais cheios e pesados.

\subsubsection{Fatores ambientais no florescimento}

\section{. Temperatura}

Os efeitos das altas temperaturas para a formação dos primórdios das inflorescências em videiras, têm sido comprovados por diversos autores, tais como Baldwin (1964), Buttrose (1974), Srinivasan e Mullins (1981). Estes pesquisadores comentam que a fase critica de resposta às altas temperaturas 
compreende um periodo de mais ou menos três semanas antes da formação do anlagen, coincidindo com o inicio de formação da gema latente.

Diferenças substanciais têm sido encontradas nos requerimentos de temperatura para a formação dos primórdios das inflorescências entre as cultivares de diferentes origens geográficas. As cultivares Thompson Seedless e Ohanez são menos frutiferas que a maioria das outras cultivares, talvez por apresentarem uma sensibilidade maior às mudanças de temperatura. Em geral, a temperatura eficiente para a diferenciação do anlagen em inflorescēncias na maioria das cultivares está entre $30^{\circ} \mathrm{C}$ e $35^{\circ} \mathrm{C}$ (Mullins et al., 1992).

\section{. Intensidade luminosa}

Altas intensidades luminosas melhoram a fertilidade das gemas latentes quando estas estão expostas diretamente a luz solar, mas a qualidade da luz não tem efeito sobre a formação da inflorescência (Mullins et al., 1992). Para que a 'Thompson Seedless' apresente um nivel considerado aceitável de gemas férteis, durante a formação das inflorescências, è necessário que haja em média 10 horas de luz solar por dia.

Segundo estudos realizados por Buttrose (1970), os efeitos da intensidade luminosa nas gemas frutiferas de videira são independentes da temperatura. Não somente as gemas de ramos expostos ao sol são mais frutiferas, como também um maior número delas se desenvolve nestes ramos. May et al. (1976) observaram que as gemas dos ramos situados no interior da copa são menos frutiferas do que aquelas dos ramos mais ensolarados. Kliewer (1981) comenta ainda, que os cachos desenvolvidos em ramos expostos ao sol são em geral maiores do que aqueles dos ramos de sombra.

Sobre a influência da temperatura e da luz nas gemas frutiferas, Buttrose (1974) concluiu que a temperatura é o principal fator para a formação dos primórdios das inflorescências, mas, de acordo com Rives (1972), a intensidade luminosa é o fator limitante. 


\section{- Nutrição mineral}

Muthukrishnan e Srinivasan (1974) em estudo sobre o estado nutricional de trinta vinhedos sob condições de clima tropical, encontraram uma correlação negativa entre o teor de nitrogênio nos peciolos e a fertilidade das gemas, enquanto que o teor de fósforo foi positivamente correlacionado com o peso dos cachos. Existem também evidências de que as reservas em $\mathrm{N}$ dos sarmentos é que são utilizadas para o desenvolvimento dos ramos, mais do que o $\mathrm{N}$ adicionado, em adubações, durante esta fase de crescimento. Baldwin (1966) constatou que baixos teores de $\mathrm{N}$, altos de $\mathrm{P}$ e estresse hídrico são fatores associados com a alta fertilidade das gemas da 'Thompson Seedless'.

Christensen (1975) em trabalho realizado na Califórnia, observou que aplicações de potássio no solo causaram um marcante aumento na fertilidade das gemas latentes em vinhedos da 'Thompson Seedless'.

Um aporte adequado de nitrogênio é necessāio para a formação do primórdio da inflorescência e para a diferenciação das flores, entretanto, um aporte elevado deste nutriente pode resultar na redução do florescimento e no exacerbado crescimento do sistema aéreo (Srinivasan e Mullins, 1981).

Kliewer (1989-90), usando doses elevadas de nitrogênio $(448 \mathrm{~kg}$ de $\mathrm{N} / \mathrm{ha}$ ), obteve aumento na produção de uvas 'Thompson Seedless', constatando, porém, uma redução no teor de sólidos solúveis e no teor de potássio do suco das uvas.

Num estudo para determinar o uso do nitrogênio pela "Thompson Seedless', Williams (1987) observou que uma significativa quantidade de $\mathrm{N}$ foi mobilizada das raizes para a parte aérea da planta, no periodo compreendido entre a brotação das gemas e o florescimento, havendo logo após, uma reposição das reservas de $\mathrm{N}$ nas raizes.

A fotossintese realizada pelas folhas, por ser um processo complexo, envolvendo diversos compostos, é influenciada de modo significativo pelos elementos essenciais à vida das plantas. Williams e Smith (1985) obtiveram uma correlação linear entre a taxa liquida de assimilação de $\mathrm{CO}_{2}$ e a concentração de $\mathrm{N}$ nas folhas de videiras. Sabendo-se que a maior quantidade do $\mathrm{N}$ nas folhas está na forma de proteinas e sendo a Ribulose 1,5-bisfosfato 
carboxilase/oxigenase (RuBPC/O ou Rubisco) a mais abundante delas e também a de maior importância na regulação do ciclo PCR (Millard, 1995), pode-se inferir sobre a importância do $\mathrm{N}$ no processo fotossintético. Williams $\mathrm{e}$ Smith (1985) observaram que folhas de videiras muito jovens têm alta concentração de $\mathrm{N}$ no limbo (mais de $5 \%$ em base de matéria seca), mas baixas taxas de fotossintese, atribuindo isto ao fato de que o aparelho fotossintético não esteja plenamente desenvolvido; a correlação positiva entre $\mathrm{N}$ e fotossintese ocorre após o amadurecimento das folhas. A taxa fotossintética durante a senescência decrescerá devido a diminuição do $\mathrm{N}$ no limbo foliar. Outros nutrientes minerais tais como o $\mathrm{P}$ também afetam a capacidade das folhas em fixar $\mathrm{CO}_{2}$, por estarem envolvidos nos processos metabólicos relacionados com a fotossintese.

\subsection{Práticas culturais e o vigor das plantas}

As condições edafoclimáticas e as práticas culturais causam influências diretas no comportamento físiológico da videira. Esse fator está intimamente relacionado com o vigor das plantas, sofrendo efeitos indiretos do ambiente $\mathrm{e}$ das práticas culturais utilizadas. O somatório de todos esses fatores interfere direta ou indiretamente na quantidade e na qualidade da produção.

Entre as práticas culturais que podem ser utilizadas como formas de controlar o excessivo vigor das plantas de videira, pode-se citar o uso de portaenxertos menos vigorosos, o controle da fertilização das plantas e o uso de retardadores de crescimento.

Em trabalho avaliando o comportamento da cultivar Thompson Seedless sobre os porta-enxertos 'Tropical', 'Harmony', 'Salt Creek' e 'Dog Ridge' na região do Submédio São Francisco, Freire et al. (1991), obtiveram maior produção por planta e aumento do peso médio dos cachos com o uso dos porta-enxertos 'Harmony' e 'Salt Creek', embora as plantas mais vigorosas tenham sido as desenvolvidas sobre o porta-enxerto 'Tropical'. 
Fluxograma do efeito das condições edafoclimáticas e práticas culturais na

fisiologia e vigor das plantas de videira, modificado de Smart (1985).

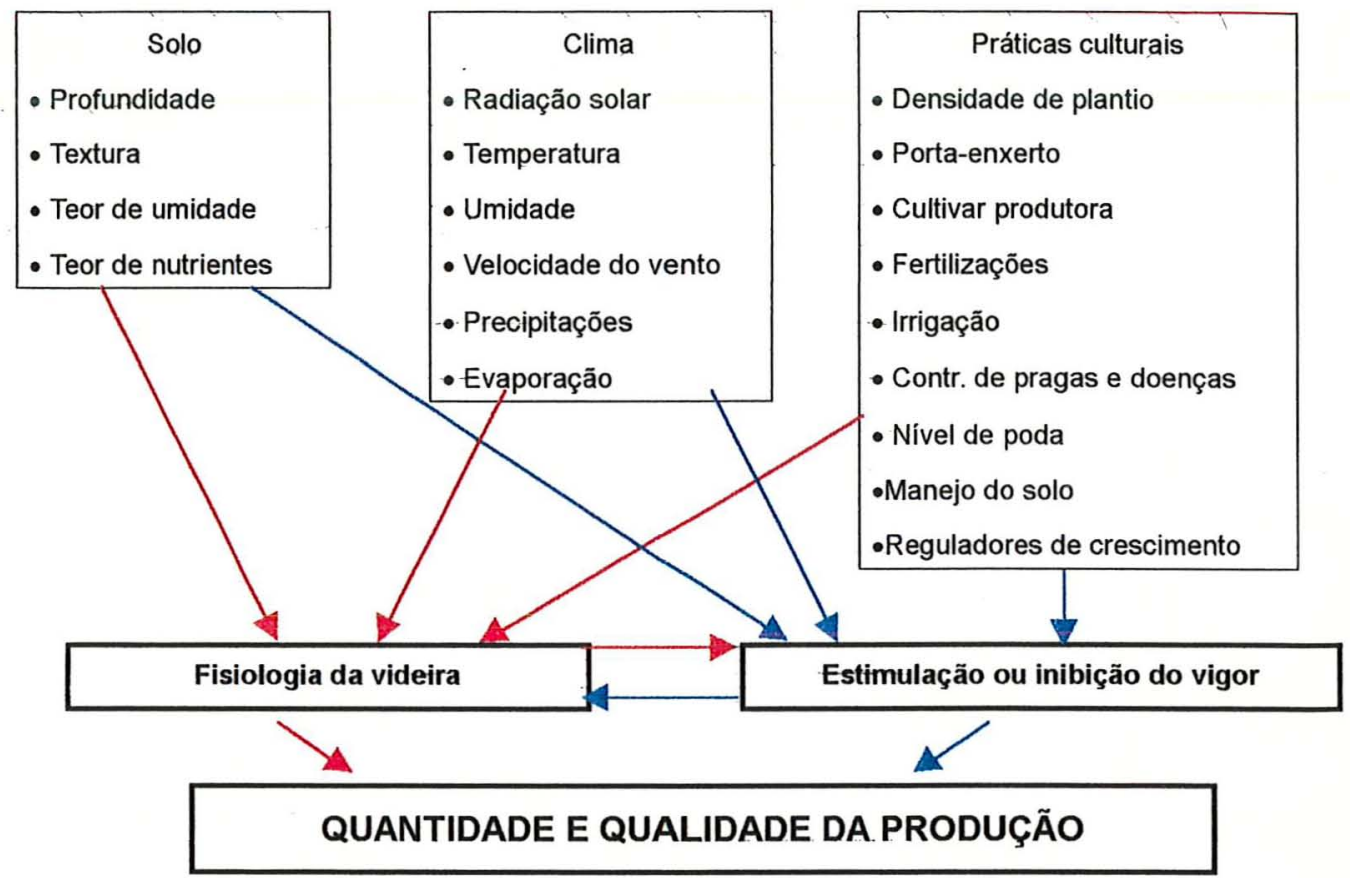

Legenda: $\quad \rightarrow$ Efeito direto

$\rightarrow$ Efeito indireto

O porta-enxerto influencia as videiras enxertadas na absorção do potássio e do magnésio, sendo que nas cultivares européias afeta particularmente o acúmulo de nitrogênio, fósforo e magnésio nas folhas e nos sarmentos da videira (Iannini, 1984). Ruhl (1989) relata que os porta-enxertos 'Freedom', 'Dog Ridge' e 'Rupestris du Lot' contribuíram para um pH mais elevado no suco das uvas das plantas enxertadas, e estas mostraram alta concentração de $\mathrm{K}^{+}$nos pecíolos, enquanto que os porta-enxertos '140R', '1202C' e '110R' produziram efeitos contrários.

Os porta-enxertos '125AA' e 'Kober 5BB', segundo Aimone e Bovio (1988), provocaram um rápido desenvolvimento das videiras da cultivar Barbera e uma precoce produção de uvas, assim como as plantas no 'Paulsen 1103' e no 'Rupestris du Lot' demonstraram um equilibrio entre o crescimento vegetativo, o peso e a qualidade dos cachos. Porta-enxertos que desfavorecem o vigor da produtora, em geral, induzem a uma melhor qualidade de produção. 
Zimmermann (1986), analisando os resultados de um trabalho com vários cultivares e porta-enxertos, chegou a conclusão que não existe um porta-enxerto universalmente apropriado e que cada cultivar exige um portaenxerto particular para mostrar compatibilidade e adaptação ótimas.

Pereira et al. (1976) fizeram observações sobre a extração de nutrientes pelos porta-enxertos 'IAC 766' e 'IAC 571-6', concluindo que as raizes deste último foram as mais efetivas na extração de nutrientes do solo. Terra et al. (1990) compararam o efeito de quatro cultivares IAC de uvas para vinho e concluiram que as maiores produçōes foram obtidas com 'Máximo' (IAC 13822) e 'Sanches' (IAC 960-9) sobre o porta-enxerto 'Tropical', no entanto a cultivar 'Rainha' (IAC 116-31), sobre o mesmo porta-enxerto, apresentou um grande vigor vegetativo e baixa produção. 


\section{EFEITO DE RETARDADORES DE CRESCIMENTO NAS CARACTERISTICAS NUTRICIONAIS DAS CULTIVARES DE VIDEIRA THOMPSON SEEDLESS E ITALIA}

\subsection{Resumo}

Com o objetivo de avaliar a variação no teor de macronutrientes como resposta ao uso de reguladores de crescimento em plantas das cultivares 'Thompson Seedless' e 'Italia', realizaram-se dois experimentos em casa-devegetação testando quatro retardadores: chlormequat $1.500 \mathrm{mg} \cdot \mathrm{L}^{-1}$; daminozide $3.000 \mathrm{mg} . \mathrm{L}^{-1}$; uniconazole $30 \mathrm{mg} . \mathrm{L}^{-1}$; cloreto de mepiquat $300 \mathrm{mg} . \mathrm{L}^{-1}$. As mudas das cultivares produtoras enxertadas sobre 'Tropical' foram transplantadas para vasos com 35L de uma mistura 1:1:1 em volume de areia, de solo e de composto orgânico. A cada 150 dias realizava-se a poda deixando-se duas varas de seis gemas. A irrigação foi por gotejamento, colocando-se em cada vaso um litro de água por dia. As videiras foram adubadas com um litro de composto orgânico e com uma solução de micronutrientes. A cada poda e durante o ciclo, a cada 15 dias, com adubos quimicos $(1,45 \mathrm{~g}$ de MAP, $3,42 \mathrm{~g}$ de nitrato de cálcio, 1,61g de uréia, 3,53g de cloreto de potássio e $1,94 \mathrm{~g}$ de sulfato de magnésio). No fim de cada ciclo, podou-se o sistema aéreo, coletando-se os peciolos das folhas e os ramos, que foram secos e pesados para determinação da massa de matéria seca. Após moagem do material seco, as amostras foram analisadas quanto ao teor de macronutrientes conforme metodologia descrita em Sarruge e Haag (1974). A análise estatistica dos resultados obtidos, feita através do programa SAS, permitiu concluir que é possivel não só diminuir o ritmo de crescimento dos ramos, como também alterar-se a concentração de 
nutrientes em plantas de videira pelo uso de retardadores de crescimento, favorecendo a formação de gemas férteis.

\subsection{Summary}

Two experiments were carried out in a greenhouse to evaluate the variation in macronutrient contents in relation of growth regulators sprays on 'Thompson Seedless' and 'Italia' grapevines Treatments comprised: chlormequat - $1500 \mathrm{mg} \cdot \mathrm{L}^{-1}$; daminozide - 3000mg.L-1; uniconazole - 30mg.L $\mathrm{L}^{-1}$; mepiquat chloride - $300 \mathrm{mg} \cdot \mathrm{L}^{-1}$ and control. The cuttings were grafted on Tropical rootstock and were rooted in sand. After 105 days of growth they were transplanted to $35 \mathrm{~L}$ pots with a mixing of $1: 1: 1$ volume of sand, soil and organic matter. Grapevines were pruned each 150 days, left two canes with six buds each one. Water was supplied through drip irrigation system $(1 \mathrm{~L} /$ plant day). Grapevines were fertilized with $1 \mathrm{~L}$ of manure and micronutrients solution at each pruning. Macronutrients ( MAP- $1.45 \mathrm{~g}, \mathrm{Ca}_{2} \mathrm{NO}_{3}-3.42 \mathrm{~g}$, urea-1.61g de , $\mathrm{KCl}-3.53 \mathrm{~g}$ and $\mathrm{MgSO}_{4}-1.94 \mathrm{~g}$ ) were suplied each 15 days during the plants growth. The petioles and the shoots were sampled each growth season (150 days) and dry matter was evaluated for production and macronutrient contents (N, P, K, Ca and Mg). Results had shown that: growth regulators spray induced alteration in the macronutrient patterns due to the decrease of shoots rate growth and increase fruitfull shoots.

\subsection{Introdução}

Estudos recentes, ao colocarem em evidência a importância do consumo de frutas frescas na alimentação humana, estão dando à uva destaque especial. Este fato tem estimulado o consumo de uvas "in natura" e na forma de passas. Em conseqüência, a 'Thompson Seedless' desponta como a cultivar de maior receptividade no mercado consumidor, por não apresentar sementes.

Em condições de clima tropical, a disseminação da 'Thompson Seedless', em plantios comerciais, tem sido inviabilizada pelo fato de as plantas apresentarem vegetação muito intensa em detrimento do desenvolvimento de inflorescências, o que acarreta uma baixa produtividade. A diferenciação e 
desenvolvimento dos primórdios florais são resultantes de complexos processos metabólicos; esses processos, regulados por fitohormônios, são altamente influenciados por condições ambientais, tais como: intensidade luminosa, temperatura, fotoperiodo e disponibilidade de água e nutrientes. A densa folhagem das videiras, resultante do excessivo crescimento vegetativo, ao impedir que a radiação solar atinja os ramos do interior da copa, é responsável pela baixa floração em condições tropicais. May et al. (1976) observaram que gemas situadas no interior da vegetação de videiras apresentavam baixa fertilidade em relação àquelas situadas no exterior do dossel, onde eram fortemente iluminadas. Buttrose (1970) já havia observado que ramos da 'Thompson Seedless' só são férteis com intensidades de luz superiores a 19,5klx. Essa relação de dependência da fertilidade das gemas com a intensidade luminosa é devida ao processo de formação de reservas, que tende a diminuir em condiçōes de sombreamento. As folhas sombreadas tem sua capacidade de fixação de $\mathrm{CO}_{2}$ radicalmente diminuída a tal ponto que as folhas que estão localizadas no interior do dossel tendem a atingir o ponto de compensação luminico, tornando-as parasitas da própria planta (Kliewer, 1981).

O controle da vegetação como prática para melhorar a quantidade e a qualidade da frutificação das videiras tem sido pesquisado por muitos autores (May et al., 1969; Lavee et al., 1977; Kliewer et al.,1987; Williams et al., 1987). Uma das maneiras de controlar, com sucesso, o desenvolvimento vegetativo è a utilização de retardadores de crescimento, substâncias sintéticas que ao serem aplicadas nas plantas atuam na atividade do meristema sub-apical. Entre as substâncias que atuam como retardadores têm-se o cloreto (2-cloroetil) trimetilamônio conhecida como chlormequat ou $\mathrm{CCC}$, o ácido succínico-2, 2dimetilidrazida, denominado daminozide ou $\mathrm{SADH}$, o uniconazole, a hidrazida maleica, o cloreto de mepiquat e o paclobutrazol. De modo geral, os retardadores de crescimento quando aplicados após a floração favorecem o desenvolvimento dos primórdios das inflorescências, provocando o aumento na produção da cultura. 
Pondera-se que prāticas controladoras da vegetação poderiam ser utilizadas como forma de equilibrar as plantas de 'Thompson Seedless' no Nordeste do Brasil, favorecendo o processo de diferenciação das gemas de forma adequada, o que resultaria numa produçăo economicamente rentável. $O$ presente trabalho teve como objetivo avaliar a variação no ritmo de crescimento dos ramos e no teor de macronutrientes em resposta ao uso de retardadores em plantas das cultivares Thompson Seedless e Italia.

\subsection{Material e Métodos}

\subsubsection{Localização dos experimentos}

Este trabalho constituiu-se de dois experimentos, um com a cultivar Italia e outro com a cultivar Thompson Seedless, que foram desenvolvidos em casa-de-vegetação, no Departamento de Botânica, localizada no Horto Bxperimental da Escola Superior de Agricultura "Luiz de Queiroz" da Universidade São Paulo, em Piracicaba (SP). A cidade de Piracicaba encontra-se a $22^{\circ} 42^{\prime}$ de latitude $S$ e $47^{\circ} 38^{\prime}$ de longitude $W$ e a $515 \mathrm{~m}$ de altitude. A região é caracterizada por um clima tropical de altitude. As temperaturas no interior da casa-de-vegetação, durante a realização dos experimentos no periodo compreendido entre 6 de janeiro de 1996 a 23 de maio de 1997 , oscilaram entre $30^{\circ} \mathrm{C}$ e $46^{\circ} \mathrm{C}$ durante o dia e $11^{\circ} \mathrm{C}$ e $23^{\circ} \mathrm{C}$ à noite.

\subsubsection{Delineamento experimental}

O delineamento experimental para cada experimento foi inteiramente casualizado com quatro repetições, onde foram avaliados três ciclos vegetativos e cinco tratamentos (controle e quatro retardadores de crescimento: chlormequat - 1500mg.L-1 ; daminozide - 3000mg.L-1; uniconazole - 30mg.L-1 e cloreto de mepiquat - 300mg. $\mathrm{L}^{-1}$ ). As parcelas eram constituidas por um vaso com uma planta cada. As plantas foram pulverizadas com 35 e 70 dias após a poda em cada ciclo avaliado. 


\subsubsection{Cultivares utilizadas}

\subsubsection{Cultivares copa}

\section{. Italia}

É a cultivar de maior expressão no Nordeste do Brasil, na região do vale do Rio São Francisco compreendida entre Casa Nova (BA) e Santa Maria da Boa Vista (PE) e Curaça (BA). Apresenta-se, nessa região, atingindo uma produtividade média de 30 a 40t/ha/ano, quando conduzida em latada com um espaçamento de $3 \mathrm{mx} 4 \mathrm{~m}$ e sob condições de irrigação. Essa cultivar será considerada o padrão em termos de equilíbrio nutricional e diferenciação de gemas.

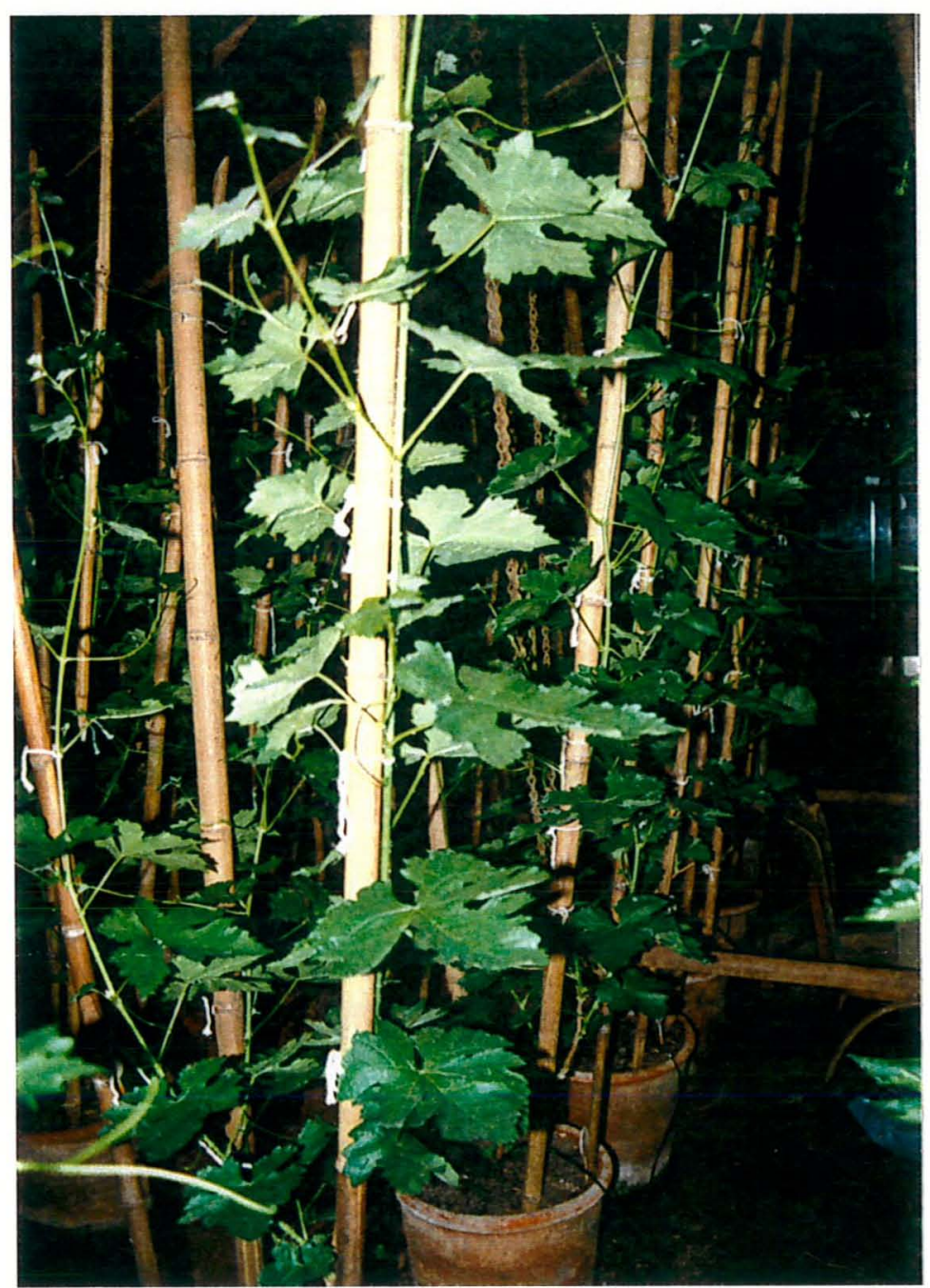

Figura 01. Plantas da cultivar Italia. 


\section{. Thompson Seedless:}

É a cultivar sem sementes mais difundida para a produção de uvas de mesa e uvas-passa. Apresentando uma apirenia natural e, além disso, uma efetiva resposta ao uso de ácido giberélico para aumentar o tamanho dos bagos, servindo como progenitora para uma série de cruzamentos, nos quais o objetivo é a obtenção de uvas apirênicas.

A produção dessa cultivar é restrita a poucas regiões do mundo, sendo a diferenciação de gemas férteis influenciada por muitos fatores, tanto extrinsecos, como intrinsecos. Como fatores extrinsecos incluem-se os fatores ambientais relativos ao solo e ao clima, e como fatores intrinsecos pode-se citar o balanço hormonal, o teor de nutrientes e todos aqueles processos fisiológicos envolvidos com o florescimento.

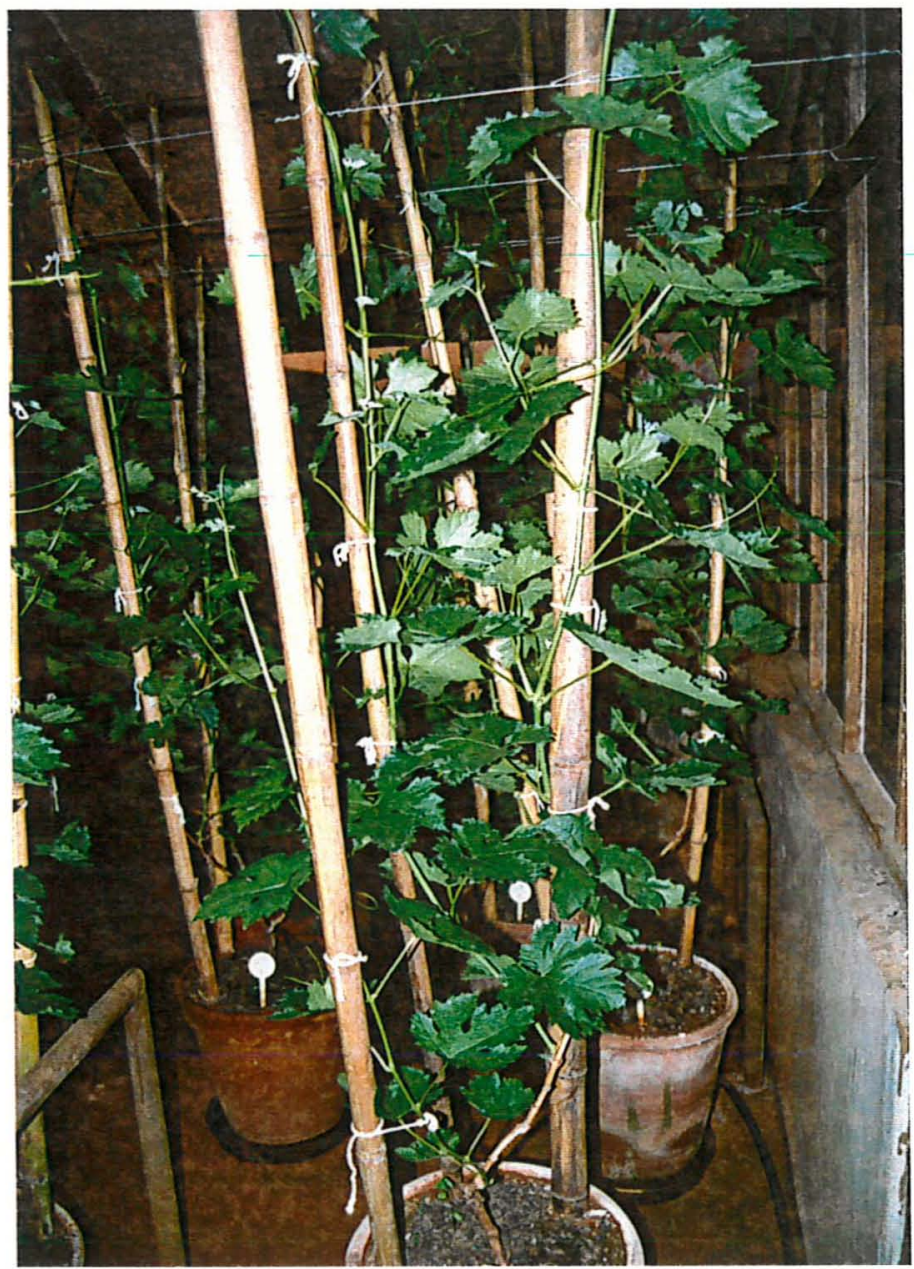

Figura 02. Plantas da cultivar Thompson Seedless. 


\subsubsection{Cultivar porta-enxerto}

\section{. Tropical (IAC 313)}

O porta-enxerto 'Tropical' é resultante do cruzamento de 'Golia' com a espécie de videira tropical Vitis cinerea realizado no I.A.C. e liberado para cultivo em 1955. E o porta-enxerto mais utilizado no trópico semi-árido do Brasil. É vigoroso, com perfeita adaptação às condiçōes climáticas tropicais e a diferentes tipos de solos. Suas folhas apresentam boa resistência às doenças $\mathrm{e}$ dificilmente caem, e seus ramos têm uma lenta lignificação. Apresenta bom indice de pegamento das estacas, com formação de mudas vigorosas. Adaptado para diversas cultivares produtoras ('Italia', 'Piratininga', 'Red Globe').

\subsubsection{Condução do experimento}

\section{- Produção das mudas}

A enxertia das estacas das cultivares produtoras sobre o porta-enxerto 'Tropical' foi realizada no Centro de Pesquisa Agropecuária do Trópico SemiÁrido - EMBRAPA, e logo a seguir foram enviadas para a ESALQ, sendo imediatamente colocadas para enraizar em sacos plásticos com areia. Após três meses e meio de desenvolvimento foram transplantadas para vasos de barro com trinta e cinco litros (35L) de volume, que continham uma mistura de areia, solo e composto orgânico na proporção de 1:1:1. Este substrato foi analisado no Laboratório de Análises de Plantas e Solos do Departamento de Quimica, sendo os resultados apresentados na Tabela 1.

Tabela 1. Atributos quimicos do substrato utilizado nos vasos.

\begin{tabular}{|c|c|c|c|c|c|c|c|c|c|}
\hline P resina & M. 0 . & $\mathrm{pHCaCl}_{2}$ & K & $\mathrm{Ca}$ & $\mathrm{Mg}$ & $\mathrm{H}+\mathrm{Al}$ & $s$ & $T$ & v \\
\hline $\mathrm{mg} \mathrm{dm}^{-3}$ & $\mathrm{gdm}^{3}$ & & & & $1 . \mathrm{dm}$ & e subs & & & $\%$ \\
\hline 343,8 & 340 & 6,75 & 41,9 & 50,1 & 23,1 & 11,3 & 115,1 & 126,4 & 91,1 \\
\hline
\end{tabular}

\section{- Adubação das plantas}

A adubação das videiras foi feita com um litro de composto organnico colocado sobre o substrato dos vasos a cada poda; e a cada 15 dias foi realizada uma adubação quimica com $1,45 \mathrm{~g}$ de $\mathrm{MAP}, 3,42 \mathrm{~g}$ de nitrato de cálcio, $1,61 \mathrm{~g}$ de uréia, 3,53g de cloreto de potássio e $1,94 \mathrm{~g}$ de sulfato de 
magnésio. Em cada ciclo vegetativo foi feita uma adubação com uma solução de micronutrientes.

\section{- Irrigação das plantas}

Os vasos foram irrigados por gotejamento, colocando-se um litro de água por dia em cada vaso, no período de clima quente. Nos meses de junho, julho e agosto, quando o clima era mais fresco, com temperaturas médias em torno de $30^{\circ} \mathrm{C}$ durante o dia e $11^{\circ} \mathrm{C}$ à noite, as irrigações eram realizadas de dois em dois dias, evitando-se que as plantas ficassem muito encharcadas.

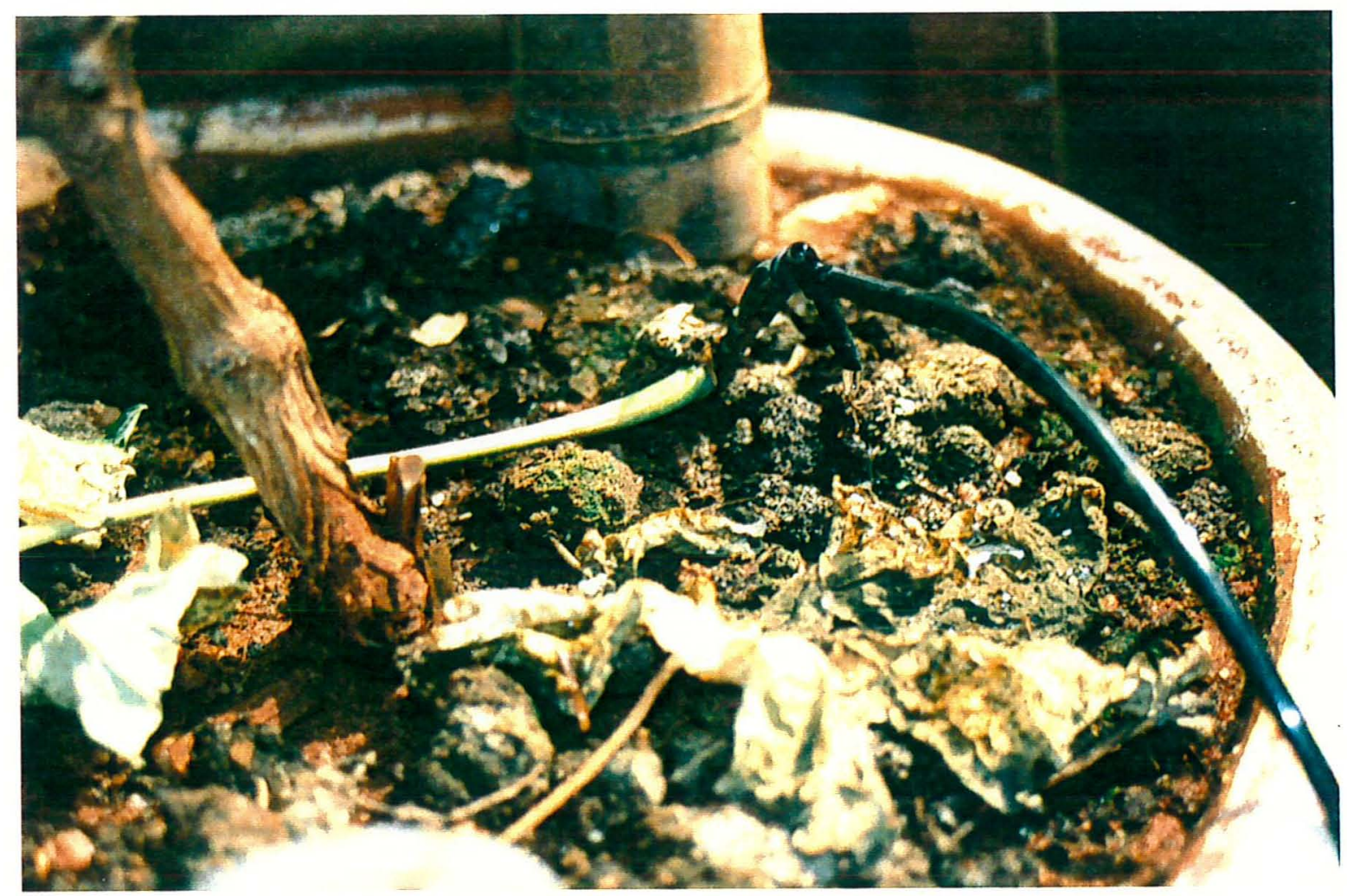

Figura 03. Detalhe do estabilizador de vaso utilizado no sistema de irrigação.

\section{- Avaliação dos experimentos}

$\mathrm{O}$ efeito dos retardadores foi avaliado pela taxa de crescimento dos ramos, nos dois primeiros ciclos, e pelo teor e quantidade acumulada de 
nutrientes nos peciolos e ramos das plantas das duas cultivares nos très ciclos em que foram conduzidos os experimentos.

Ao fim de cada ciclo vegetativo realizava-se a poda do sistema aéreo, coletando-se os peciolos das folhas e os ramos, que eram levados a secar em estufa à $65^{\circ} \mathrm{C}$ por 72 horas, pesados para determinação da massa de matéria seca e a seguir moídos. Apôs moagem do material seco, as amostras foram analisadas quanto ao teor de macronutrientes conforme metodologia descrita em Sarruge e Haag (1974).

\section{- Análise estatística}

Os resultados obtidos foram submetidos à análise estatistica através do programa SAS, realizando-se a análise de variância uni e multivariada, usando-se os teste F, para a análise univariada e os testes de Wilks, Pillai, Hotelling e Roy para as análises multivariadas.

\subsection{Resultados}

\subsubsection{Curva de crescimento das plantas}

O crescimento avaliado por meio de mediçōes semanais dos ramos nas plantas das cultivares Italia e Thompson Seedless foi realizado durante os dois primeiros ciclos do experimento e os resultados foram bastante semelhantes. Os dados foram trabalhados separadamente por ciclo e por cultivar através de uma análise multivariada, transformando as medidas em equações do segundo grau $\left(y=b_{0}+b_{1} x-b_{2} x^{2}\right)$, em que $b_{0}$ representa a medida inicial, ou seja, $a$ altura em que a curva corta o eixo dos y, quando iniciaram-se as medições; $b_{1}$ é o coeficiente angular e representa o ângulo formado pela curva em relação ao eixo dos $y$, significando a velocidade inicial com que os ramos se desenvolveram; e $b_{2}$, sendo negativo, representa que a curva mostra-se côncava em relação ao eixo dos $\mathrm{x}$, havendo um ponto de máximo comprimento dos ramos, a partir do qual as plantas param de crescer. 


\section{. Italia}

\section{- Primeiro ciclo}

A análise da curva de crescimento das plantas (Figura 04) mostra que é significativa a diferença inicial $\left(b_{0}\right)$ apresentada pelos ramos antes da aplicação dos retardadores, deduzindo-se dai que as plantas apresentavam diferentes condições de vigor.

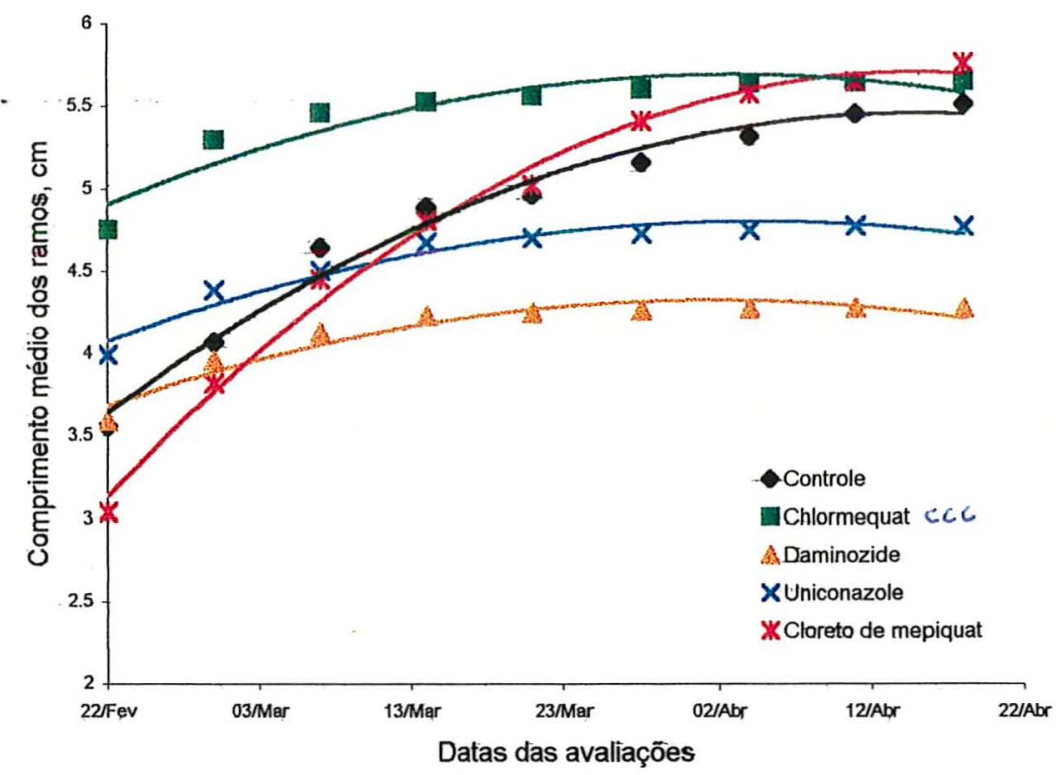

Figura 04. Efeito dos tratamentos sobre o crescimento dos ramos das plantas da cultivar Italia, no primeiro ciclo vegetativo de 06/01 a 13/06 de 1996.

As plantas tratadas com os retardadores chlormequat, daminozide e uniconazole tiveram sua taxa inicial de crescimento diminuída, pois o coeficiente angular das curvas $\left(b_{1}\right)$ é significativamente menor do que aqueles apresentados pelas curvas das plantas controle e daquelas em que foi aplicado o retardador cloreto de mepiquat.

Ao comparar-se as curvas de crescimento do controle e do cloreto de mepiquat com as curvas dos outros retardadores através da análise multivariada observa-se haver uma significância estimada a $0,1 \%$ na diferença entre as mesmas pelo teste de Roy, o que confirma a eficiência dos retardadores chlormequat, daminozide e uniconazole em diminuir o crescimento das plantas tratadas. Quando se analisa o paralelismo entre as 
curvas de crescimento observa-se também que o efeito destes retardadores é muito semelhante entre si, não havendo diferença significativa entre elas. $O$ chlormequat e o uniconazole, assim como o cloreto de mepiquat induzem alterações nos padrões de crescimento e desenvolvimento das plantas em contraposição aos efeitos das giberelinas, entretanto, o último retardador foi utilizado em dose insuficiente para causar qualquer efeito contrário ao crescimento das videiras.

\section{- Segundo ciclo}

A medida inicial dos ramos das plantas, neste segundo ciclo, foram semelhantes, não havendo antes da aplicação dos retardadores, diferença significativa entre as medidas iniciais $\left(b_{0}\right)$ das curvas de crescimento dos diversos tratamentos (Figura 05). Ao contrastar-se os coeficientes angulares $\left(b_{1}\right)$ das curvas foi observada uma diferença significativa a $1 \%$ de probabilidade nas plantas tratadas com daminozide em relação às demais, denotando que a velocidade inicial de crescimento dos ramos foi semelhante tanto nas plantas controle como nas plantas tratadas com chlormequat, uniconazole e cloreto de mepiquat.

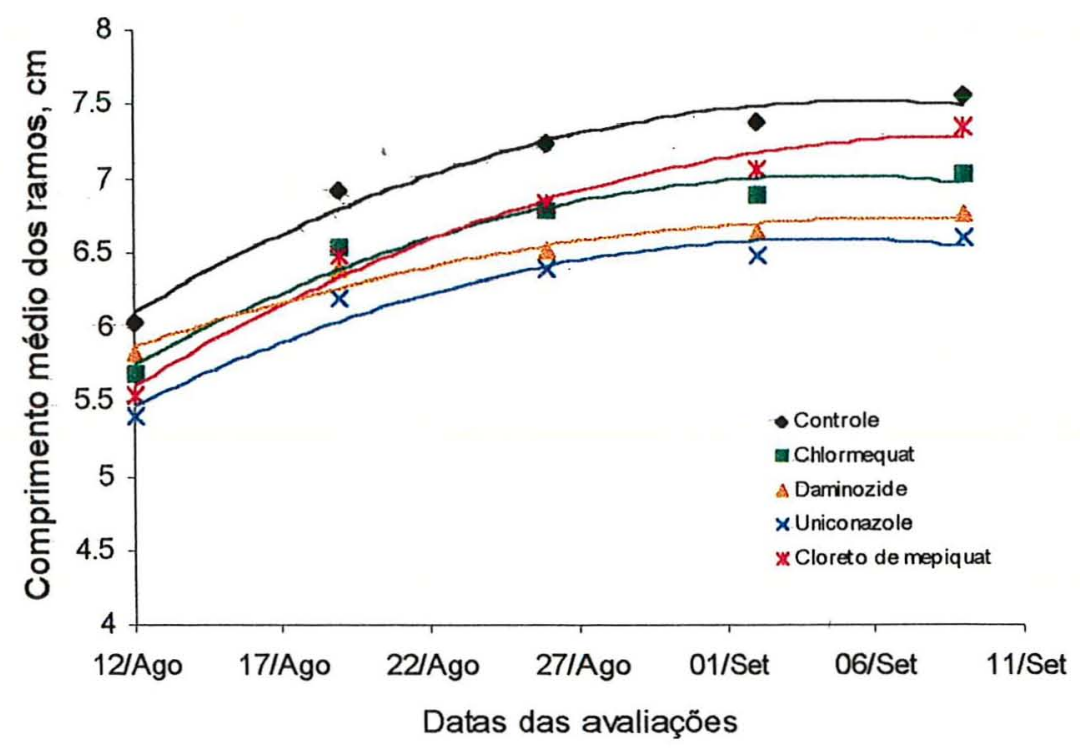

Figura 05. Efeito dos tratamentos sobre o crescimento dos ramos das plantas da cultivar Italia, no segundo ciclo vegetativo de 14/06 a 11/11 de 1996. 
Esse padrão de crescimento se manteve durante o período avaliado, com diferença significativa a $5 \%$ de probabilidade em $b_{2}$, quando $b_{0}=0$, denotando que o ponto máximo de crescimento das plantas tratadas com daminozide foi menor que o dos demais tratamentos.

\section{. Thompson Seedless}

\section{- Primeiro ciclo}

A análise da primeira medida do comprimento dos ramos $\left(b_{0}\right)$ mostrou haver diferença significativa a $1 \%$ de probabilidade somente entre os tratamentos de controle e o que fez uso do cloreto de mepiquat, que apresentaram valores extremos (Figura 06). Essa diferença no comprimento inicial dos ramos é devida às características próprias de cada planta, não sendo decorrente dos tratamentos empregados.

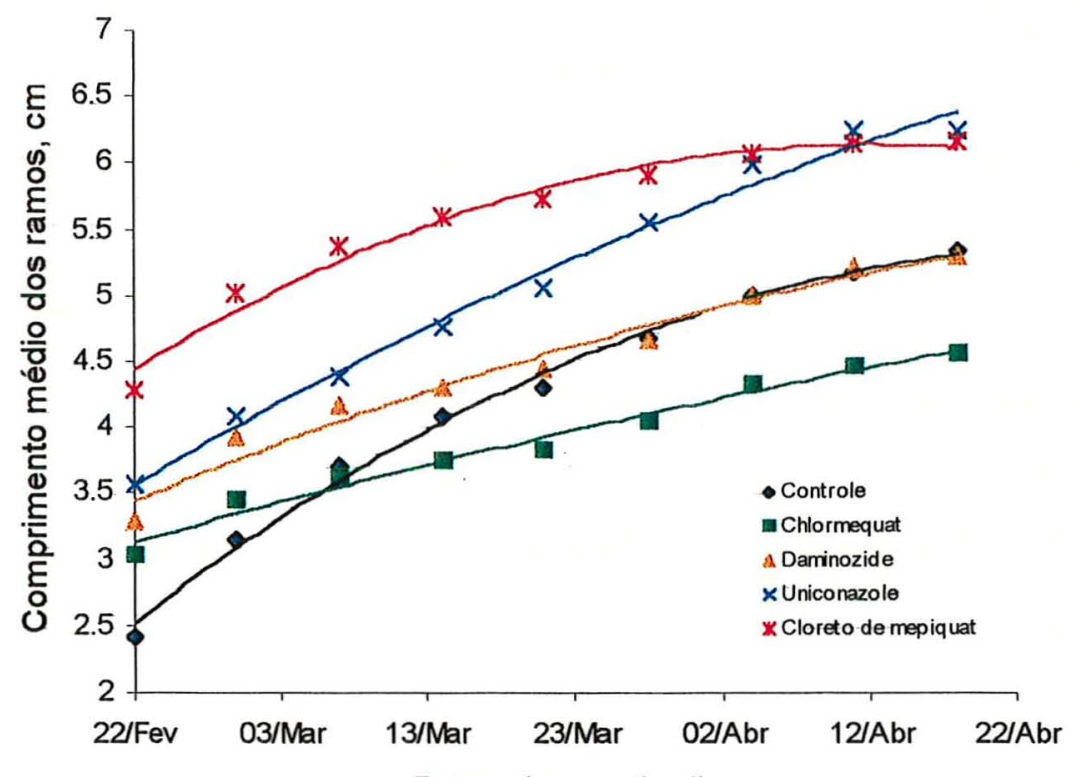

Datas das avaliações

Figura 06. Efeito dos tratamentos sobre o crescimento dos ramos das plantas da cultivar Thompson Seedless, no primeiro ciclo vegetativo de 06/01 a 13/06 de 1996.

Quanto à taxa inicial de crescimento $\left(b_{1}\right)$, o efeito dos tratamentos foi semelhante aos apresentados pela cultivar Italia. Os tratamentos diferiram entre si a $5 \%$ de probabilidade, sendo essa diferença devida a ação dos 
retardadores chlormequat, daminozide e uniconazole sobre as plantas que mostraram uma taxa inicial de crescimento mais reduzida do que aquelas do controle e as do cloreto de mepiquat, com significância a $1 \%$ de probabilidade.

Quando se analisou o $b_{2}$ houve uma diferença com $5 \%$ de probabilidade entre os tratamentos de controle e com cloreto de mepiquat em comparação com os outros retardadores, significando que o ponto máximo de crescimento dos ramos foi atingido em diferentes comprimentos segundo o tratamento utilizado.

Pela análise multivariada comprova-se que houve uma diferença à $5 \%$ de probabilidade entre os tratamentos, quer pelo teste de Pillai, quer pelo teste de Roy. Em relação as curvas de crescimento das planta controle e das tratadas com cloreto de mepiquat, a análise multivariada confirmou não haver diferença entre elas.

As respostas das plantas da cultivar Thompson ao uso de retardadores não apresentam um paralelismo entre si, havendo uma diferença a $5 \%$ de probabilidade pelo teste de Roy. Essa diferença é devida a falta de paralelismo entre as curvas das plantas controle e das tratadas com cloreto de mepiquat em relação as dos outros retardadores, que foram diferentes a $5 \%$ de probabilidade em todos os testes efetuados (Wilks, Pillai, Hotelling e Roy). Quando se compara somente as curvas de crescimento dos tratamentos chlormequat, daminozide e uniconazole, observa-se não haver diferença entre elas, ou seja, existe um paralelismo na resposta em crescimento das plantas tratadas com estes retardadores. O mesmo é observado entre o controle e o cloreto de mepiquat.

\section{. Segundo ciclo}

A análise do $b_{0}$ demonstra claramente a diferença a $0,1 \%$ de probabilidade na medida inicial dos ramos apresentada pelas plantas da cultivar Thompson entre o tratamento controle e o cloreto de mepiquat em relação ao outros retardadores (Figura 07), no entanto essa medida é devida às diferenças de vigor entre as próprias plantas. 
Os resultados da análise do coeficiente angular $b_{1}$ demonstram haver diferença a $1 \%$ de probabilidade na taxa inicial de crescimento dos ramos devida ao uso dos retardadores chlormequat, daminozide e uniconazole em relação ao controle e ao cloreto de mepiquat.

A curva de crescimento para cada retardador apresentou ponto máximo diferente a $5 \%$ de probabilidade, ou seja, no máximo crescimento, os ramos tinham diferentes comprimentos.

A análise multivarida das curvas de crescimento demonstra haver diferença entre os tratamentos a $1 \%$ de probabilidade pelos testes de Wilks e Pillai e a $0,1 \%$ de probabilidade pelos testes de Hotelling e Roy.

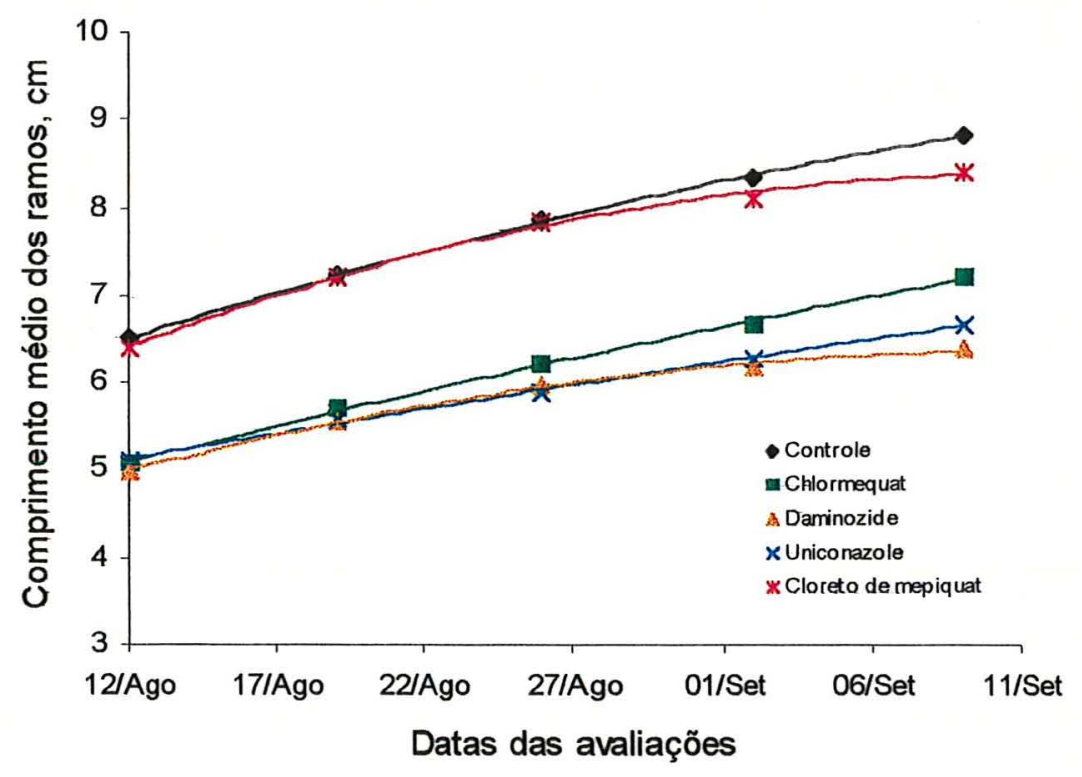

Figura 07. Efeito dos tratamentos sobre o crescimento dos ramos das plantas da cultivar Thompson Seedless, no segundo ciclo vegetativo de 14/06 a 11/11 de 1996.

Ao realizar-se o contraste entre os tratamentos chlormequat, daminozide e uniconazole, a diferença detectada entre eles pelos testes de Wilks, Hotelling e Roy é de $5 \%$ de probabilidade.

E contrastrando-se os tratamentos controle e cloreto de mepiquat com os tratamentos que usaram os outros retardadores, verifica-se em todos os testes aplicados uma diferença a $0,1 \%$ de probabilidade no efeito desses tratamentos sobre o crescimento das plantas. 


\subsubsection{Diferença entre comprimento final e inicial dos ramos (CF-CI) e massa da matéria seca (MMS)}

\section{. Italia}

$O$ efeito dos retardadores de crescimento sobre a diferença entre o comprimento final e o inicial dos ramos, foi significativo a $0,1 \%$ de probabilidade no primeiro ciclo, quando as plantas se apresentavam menos vigorosas (Tabela 2). No segundo e terceiro ciclos, as plantas apresentaram uma quantidade maior de brotações laterais que foram medidas e somadas ao comprimento final dos ramos. Este fato pode estar associado com o aumento do vigor das plantas no decorrer do ciclos vegetativos. As plantas que apresentaram o menor crescimento nos três ciclos avaliados foram as tratadas com daminozide, e o maior crescimento dos ramos foi verificado nas plantas tratadas com cloreto de mepiquat e não nas plantas controle como era esperado.

Os tratamentos causaram um efeito significativo a $1 \%$ de probabilidade no primeiro ciclo e a $5 \%$, no terceiro ciclo, sobre a massa de matéria seca dos ramos das videiras da cultivar Italia. As plantas tratadas com chlormequat produziram maior quantidade de matéria seca nos três ciclos avaliados, inobstante a diferença entre o comprimento final e inicial dos ramos destas plantas não ter sido a mais expressiva.

\section{. Thompson Seedless}

Embora as curvas de crescimentos dos ramos tenham sido significativamente diferentes, tanto no primeiro como no segundo ciclo, não foi constatada diferença nos segmentos dos ramos crescidos entre o inicio e o fim das medições, em nenhum dos três ciclos (Tabela 3).

A produção de matéria seca dos ramos teve diferença significativa a $0,1 \%$ de probabilidade apenas no segundo ciclo, não havendo uma uniformidade de respostas entre os ciclos. 


\subsubsection{Teor e quantidade acumulada de nutrientes nos ramos}

\section{. Italia}

$\mathrm{O}$ teor de $\mathrm{N}$ nos ramos foi significativamente diferente a $5 \%$ de probabilidade no segundo ciclo, não apresentando diferença nos outros ciclos (Tabela 2). Quanto à quantidade acumulada de $\mathrm{N}$ nos ramos, as médias apresentadas pelos tratamentos foram diferentes à $5 \%$ de probabilidade no primeiro e terceiro ciclos; no segundo ciclo a diferença ente os teores de $\mathrm{N}$ foi mais acentuada, com significância de $0,1 \%$ de probabilidade.

As médias do teor de $\mathrm{P}$, bem como as das quantidades acumuladas desse nutriente foram diferentes somente no segundo ciclo, onde as probabilidades foram de $5 \%$ e $0,1 \%$, respectivamente.

Entre os tratamentos não houve diferença nas médias do teor de $\mathrm{K}$ nos ramos das videiras da cultivar Italia.

Em relação à quantidade acumulada de $\mathrm{K}$ nos ramos, o efeito dos tratamentos foi significativo a $5 \%$ de probabilidade somente no segundo ciclo.

$\mathrm{O}$ efeito dos tratamentos sobre o teor e a quantidade acumulada dos outros macronutrientes não foi significativa.

\section{. Thompson Seedless}

Não se constatou diferença significativa nos teores de $\mathrm{N}$ nos ramos da cultivar Thompson; houve, entretanto, uma significativa diferença a $0,1 \%$ de probabilidade na quantidade acumulada deste elemento no segundo ciclo de crescimento (Tabela 3).

A diferença entre os tratamentos, no que tange ao teor de $\mathrm{P}$, foi significativa a $5 \%$ de probabilidade no terceiro ciclo de crescimento. Quanto à quantidade acumulada houve uma significância de $5 \%$ de probabilidade apenas no primeiro ciclo.

$\mathrm{O}$ efeito dos tratamentos sobre os teores de $\mathrm{K}$ foi significativo apenas no terceiro ciclo a $1 \%$ de probabilidade. Com relação às quantidades acumuladas de $\mathrm{K}$, os tratamentos tiveram efeitos significativos a $5 \%$ de probabilidade nos segundo e terceiro ciclos. 


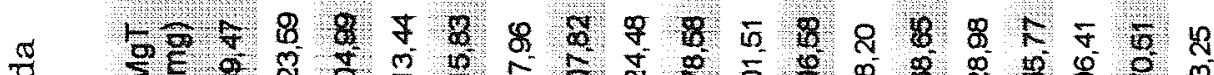

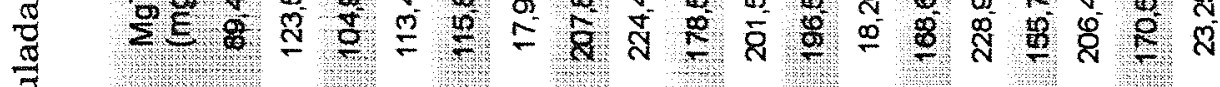
2.

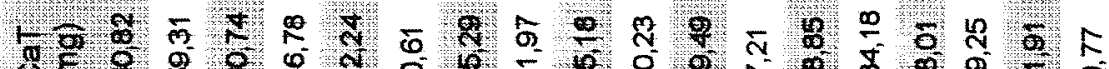

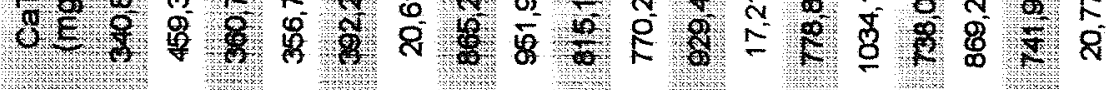

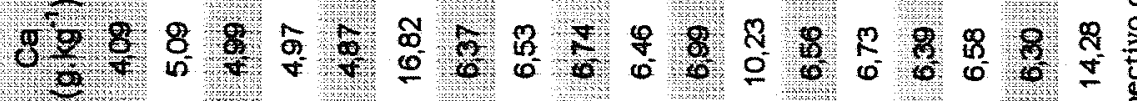

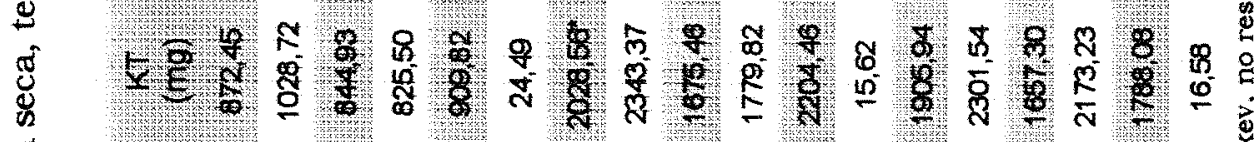

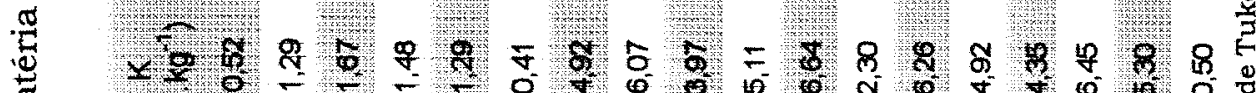
g

ชั

. எ

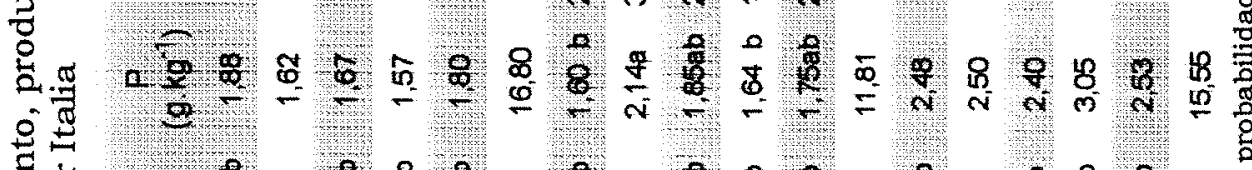

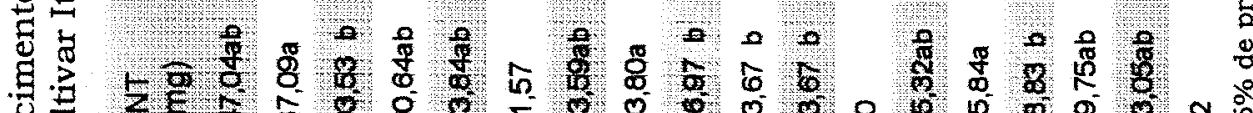

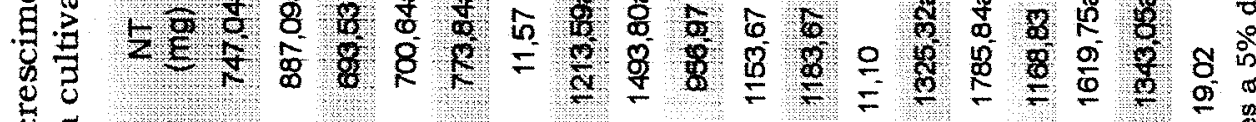

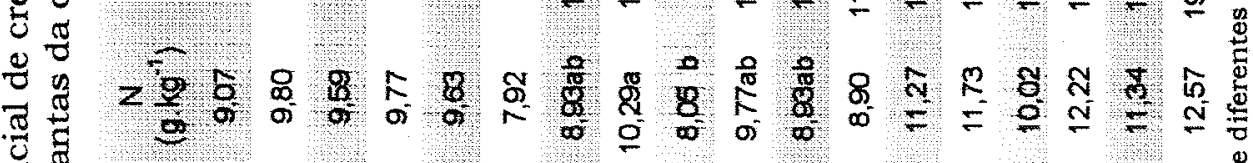

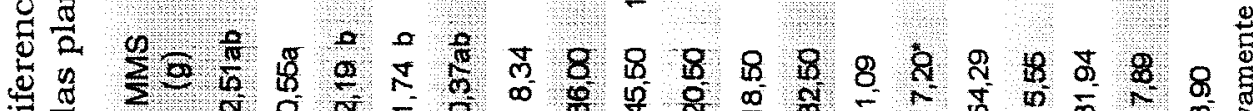

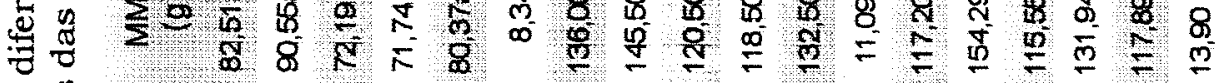

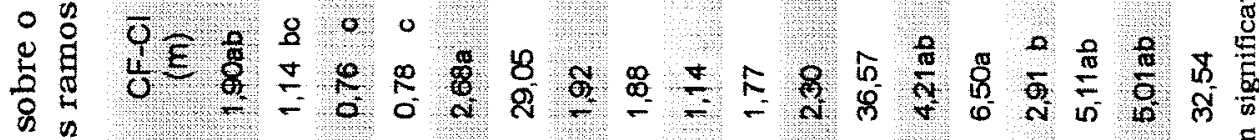

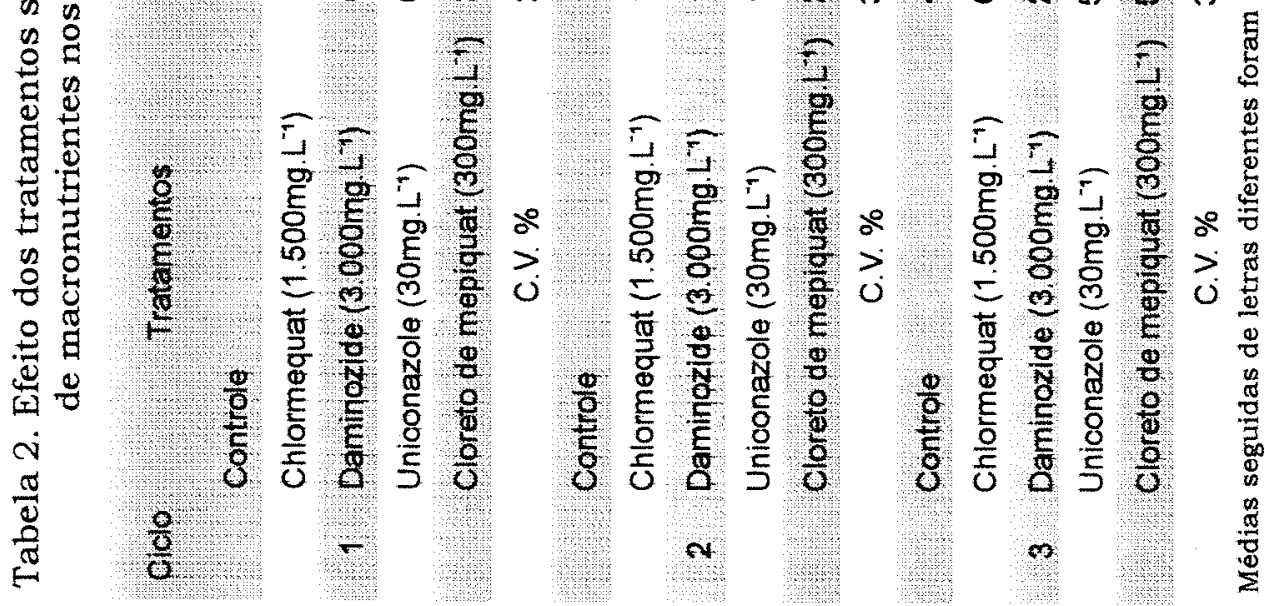




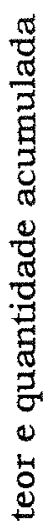

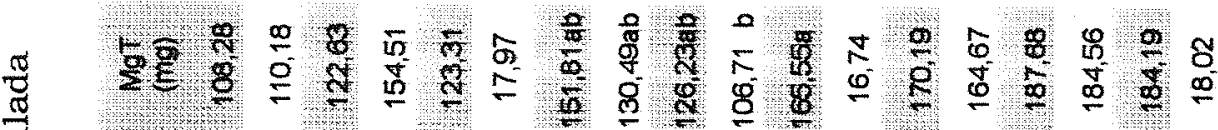

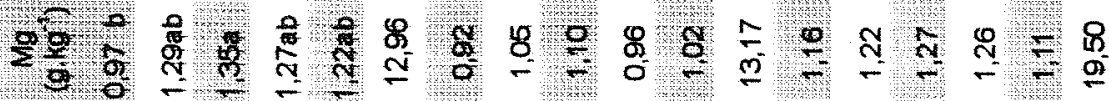
与。

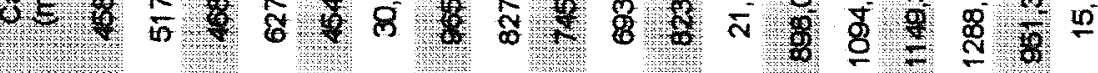

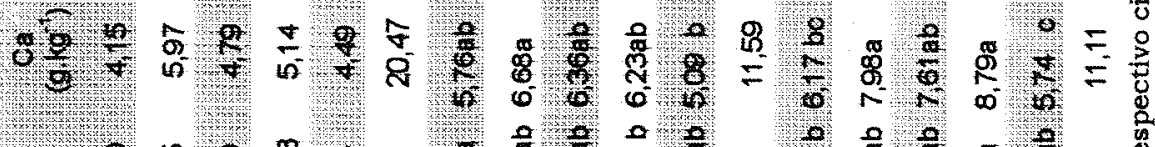
t)

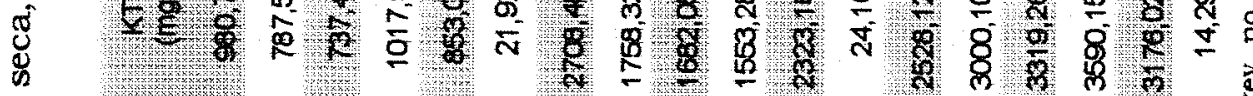

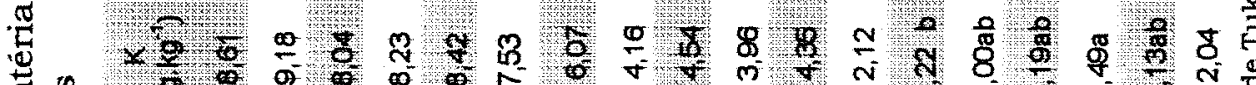
西 0. 苟 -

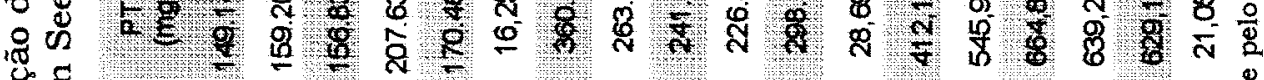
ว क्

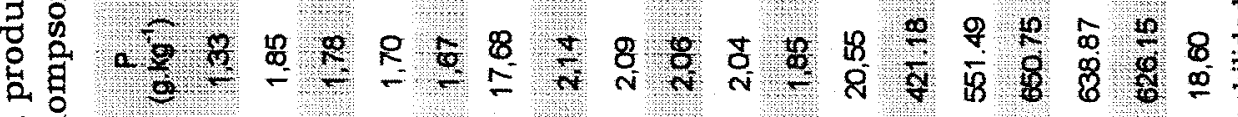

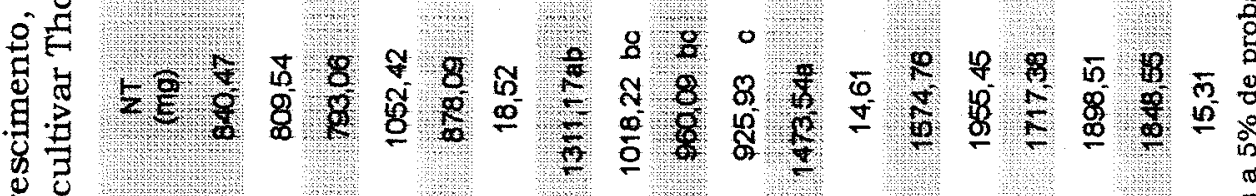

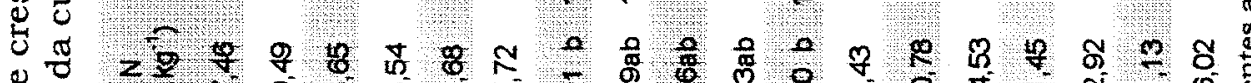

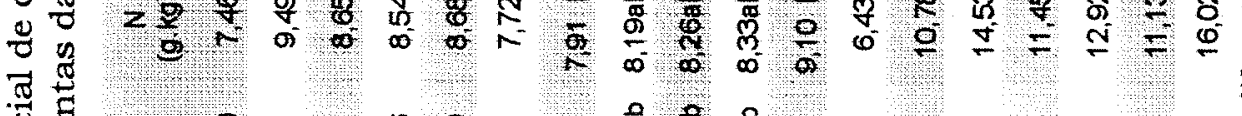

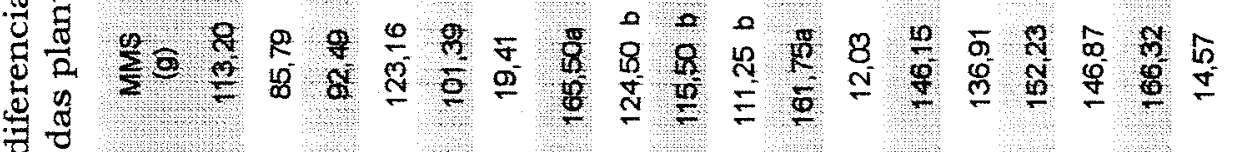

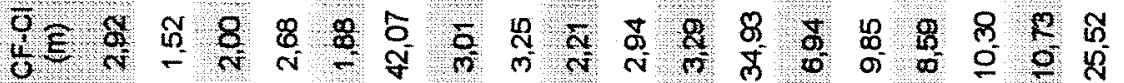
案

然

要

용

这

i

$\frac{\frac{\pi}{4}}{\frac{\pi}{n}}$

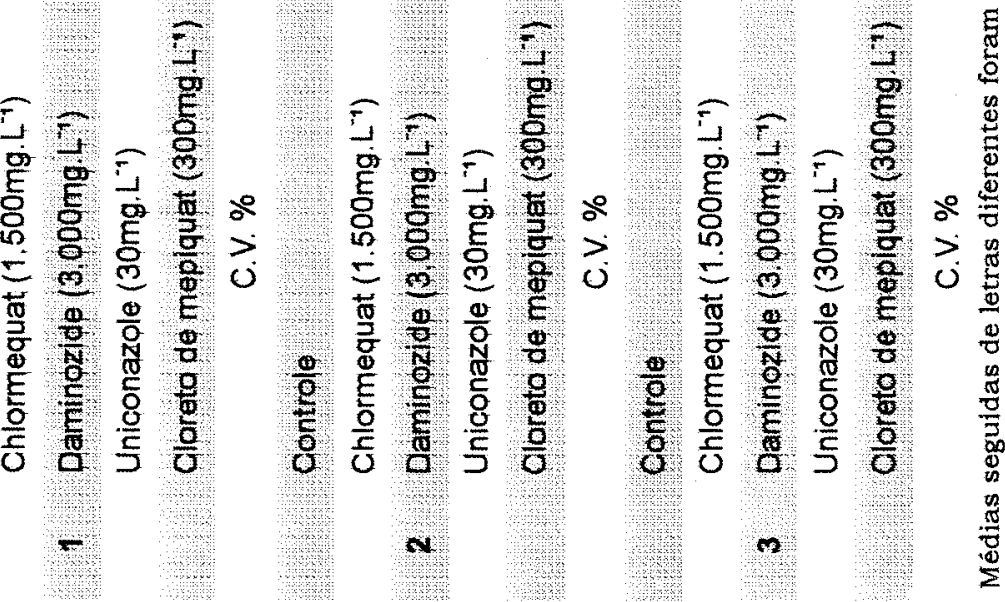


A diferença entre os tratamentos sobre o teor e a quantidade acumulada de $\mathrm{Ca}$ foi significativa no terceiro ciclo com probabilidade a $0,1 \%$ e a $5 \%$, respectivamente.

$\mathrm{O}$ teor de $\mathrm{Mg}$ foi afetado pelos tratamentos no primeiro ciclo com $5 \%$ de probabilidade, enquanto que a quantidade total sofreu influência somente no segundo ciclo a $5 \%$ de probabilidade.

\subsubsection{Teor e quantidade acumulada de nutrientes nos peciolos}

\section{. Italia}

Constatou-se marcante influência dos tratamentos sobre o teor e a quantidade acumulada de macronutrientes no terceiro ciclo de crescimento da cultivar Italia (Tabela 4). Nos teores e quantidades acumuladas de N, P, K, Ca foram significativos à $1 \%, 0,1 \%, 5 \%, 1 \%, 5 \%, 0,1 \%, 5 \%$ e $1 \%$ de probabilidade, respectivamente. Com relação ao $\mathrm{Mg}$ só foram significativos à $5 \%$ de probabilidade na quantidade acumulada.

No primeiro ciclo só o $\mathrm{K}$ apresentou diferenças significativas de teor e quantidade acumulada a $1 \%$ e $5 \%$ de probabilidade, respectivamente.

No segundo ciclo somente o teor de Ca sofreu influência significativa a $5 \%$ de probabilidade.

\section{. Thompson Seedless}

No primeiro ciclo, observou-se que os tratamentos causaram efeito significativo no teor de $\mathrm{N}$ e $\mathrm{K}$ a $5 \%$ e $1 \%$ de probabilidade, respectivamente (Tabela 5). As diferenças causadas pelos tratamentos nas quantidades acumuladas de nutrientes só foram significativas à $5 \%$ de probabilidade no $\mathrm{Ke}$ Mg.

No segundo ciclo, só foi significativo o efeito dos tratamentos sobre o teor de $\mathrm{Mg}$ a $1 \%$ de probabilidade.

No terceiro ciclo, não se constatou influência dos tratamentos sobre o teor e a quantidade acumulada de nutrientes nos peciolos. 


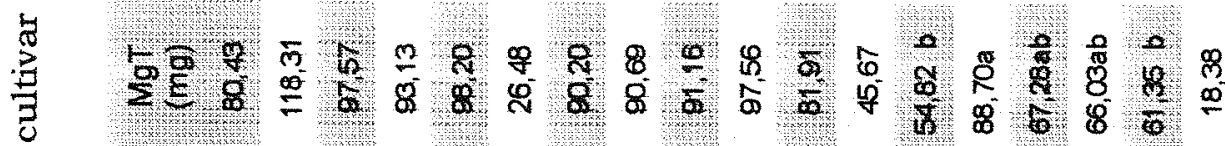

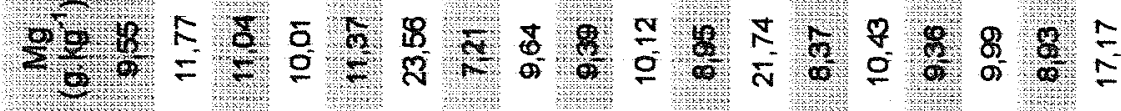

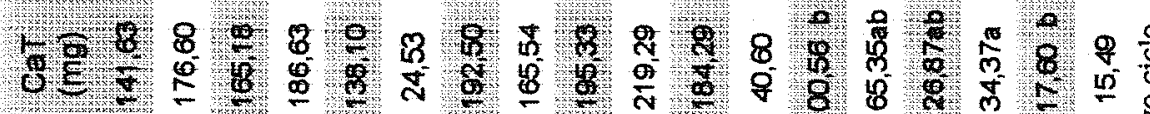

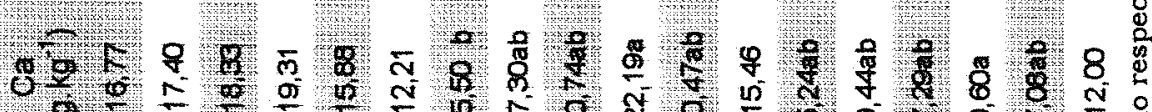

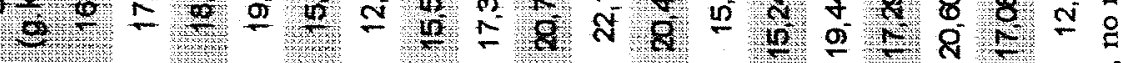

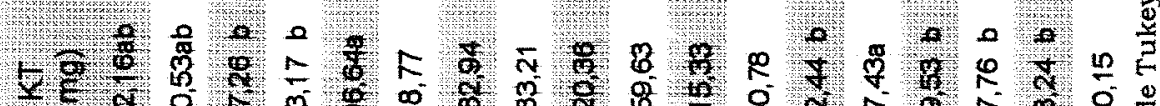

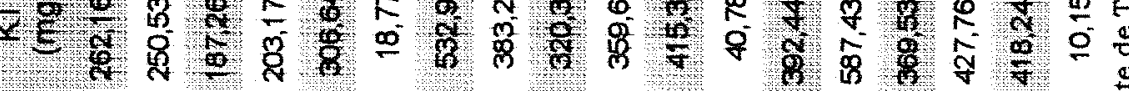

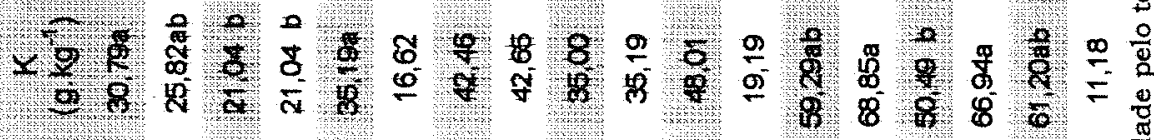

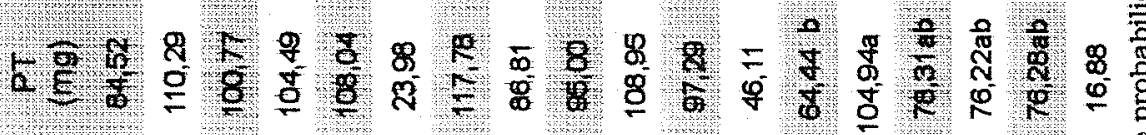

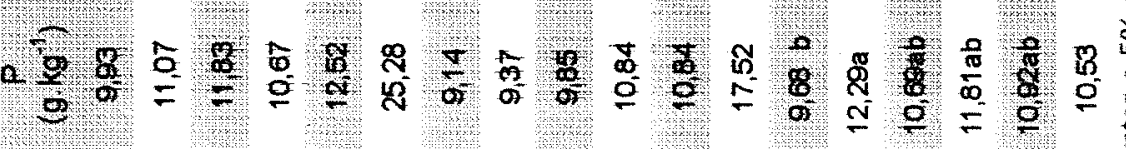
ᄂล

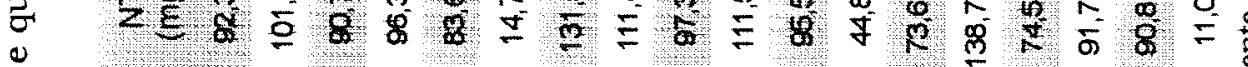

蓠

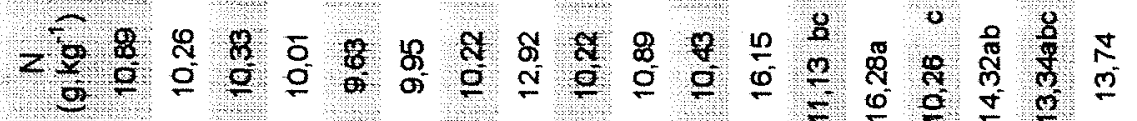
ํㅐㅇ : 造䍃 $\dot{\square}$ $\frac{\pi}{0.0}$
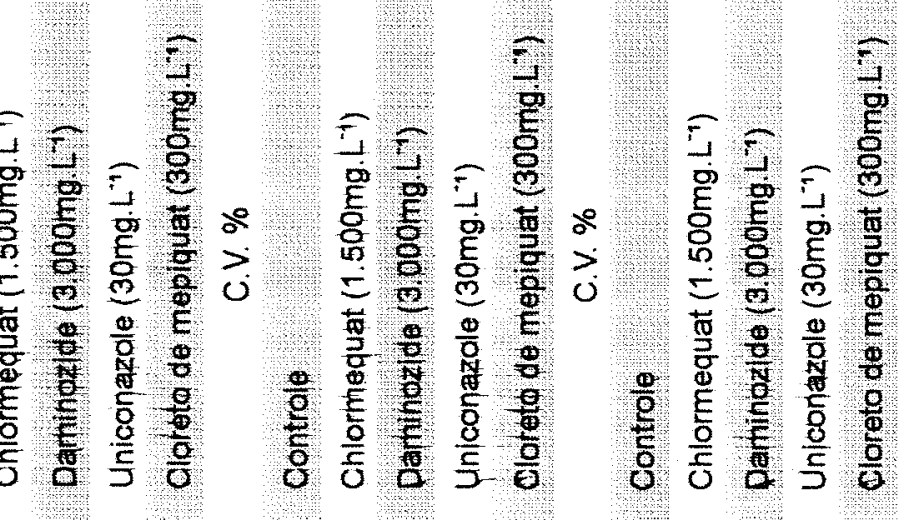


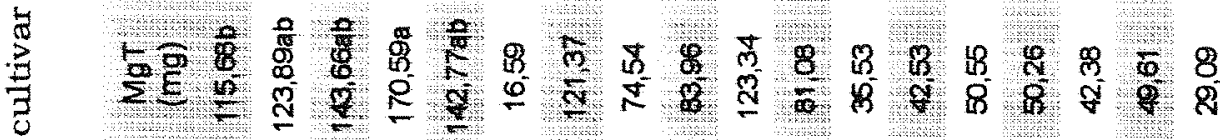

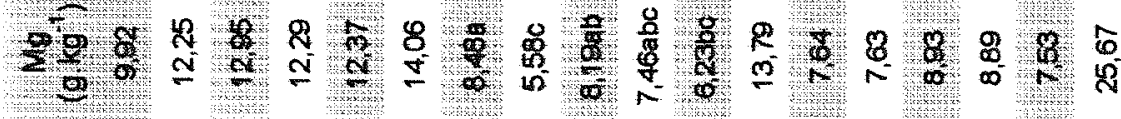

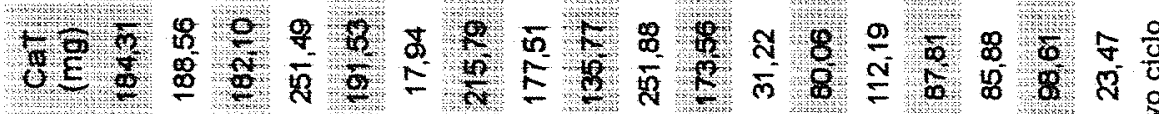

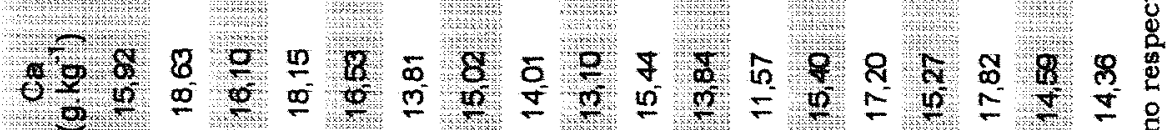
VE.

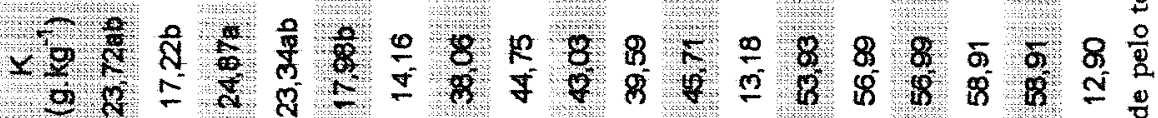
b.

รด

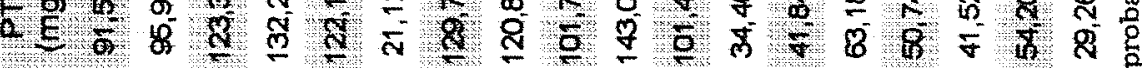

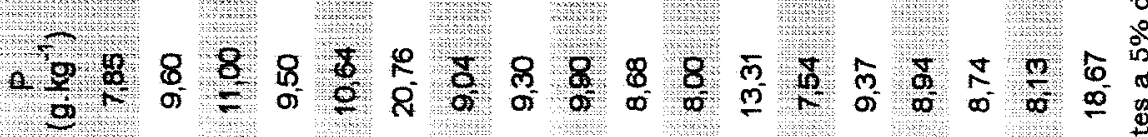
Е

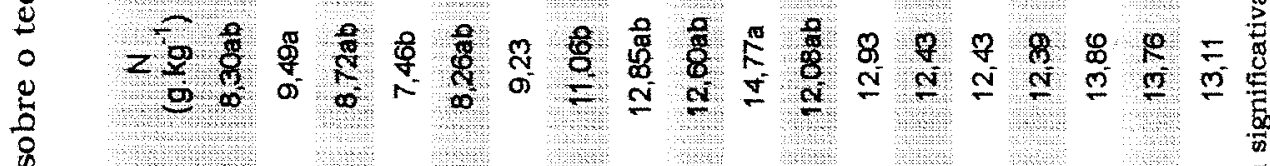

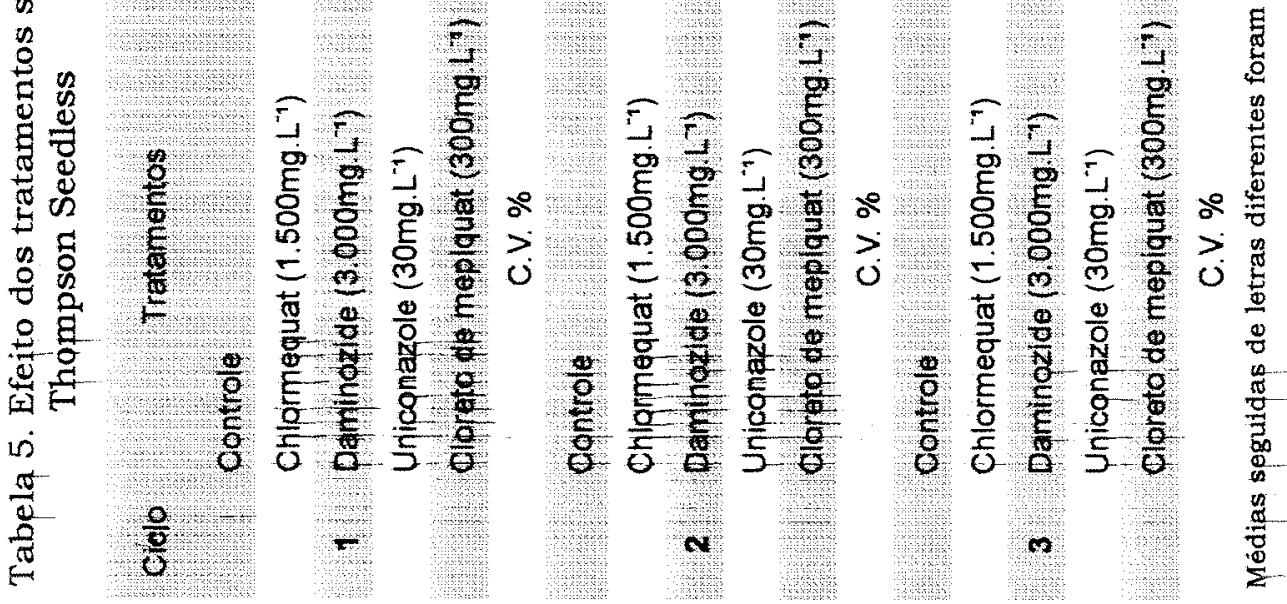




\subsubsection{Produção de paniculas florais}

O efeito dos retardadores sobre o aparecimento de panículas florais só foi constatado na cultivar Italia (Tabela 6).

Tabela 6.Porcentagem de plantas da cultivar Italia que produziram panículas florais.

\begin{tabular}{|ccc|} 
Tratamentos & $\begin{array}{c}\text { \% plantas floradas } \\
2^{\circ} \text { Ciclo }\end{array}$ & $\begin{array}{c}\text { \% plantas floradas } \\
3^{\circ} \text { Ciclo }\end{array}$ \\
\hline Controle & 0 & 0 \\
Chlormequat & 50 & 75 \\
Daminozide & 0 & 0 \\
Uniconazole & 50 & 75 \\
Cloreto de mepiquat & 0 & 25 \\
\hline
\end{tabular}

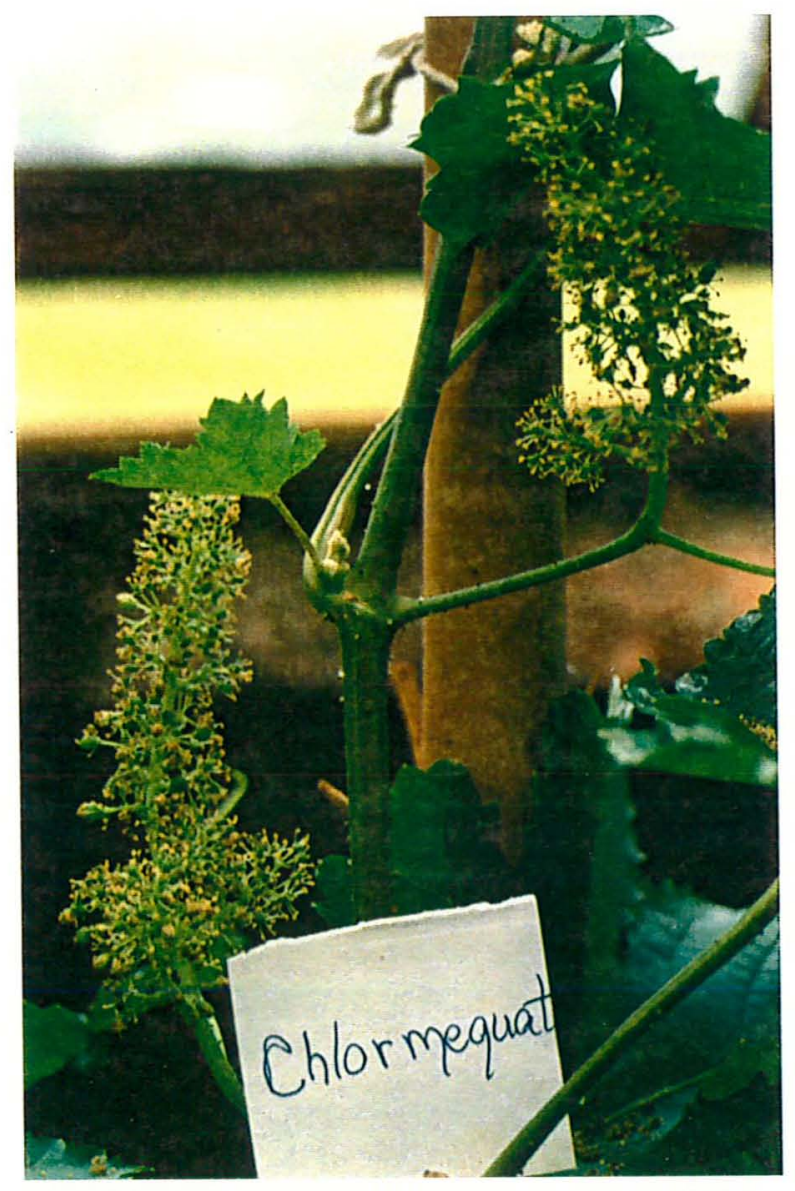

Figura 08. Panículas florais em planta da cultivar Italia tratada com chlormequat. 


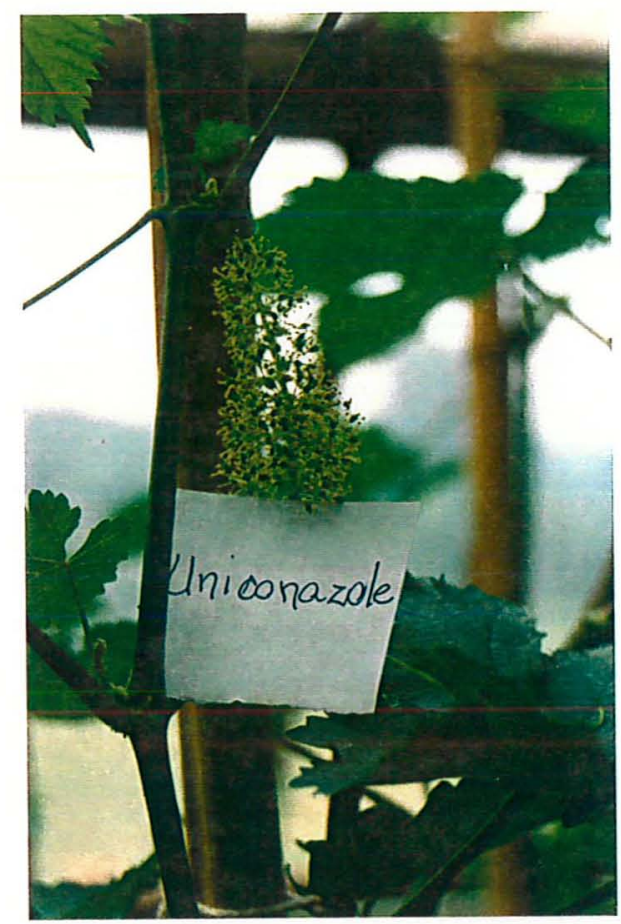

Figura 09. Panícula floral em planta da cultivar Italia tratada com uniconazole.

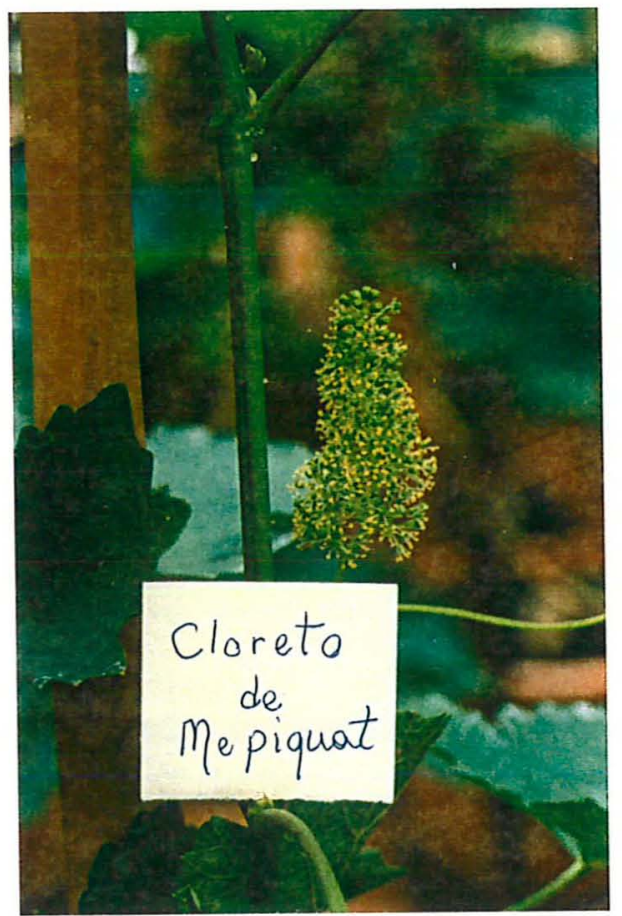

Figura 10. Panícula floral em planta da cultivar Italia tratada com cloreto de mepiquat. 


\subsection{Discussão}

\subsubsection{Curva de crescimento das plantas}

O efeito dos retardadores chlormequat, uniconazole e daminozide sobre o comprimento dos ramos das videiras quer da cultivar Italia, quer da cultivar Thompson Seedless foi semelhante ao obtido por Jaumien et al. (1986) em plantas jovens de pereiras, que apresentaram menor comprimento dos entrenós com a utilização de chlormequat e daminozide. Ionescu (1986) obteve um controle de $21 \%$ no crescimento das cultivares de videira Crîmposie selectionata e Tamioasa româneasca com o uso de chlormequat, entretanto, ocorreu também uma redução na quantidade de fotoassimilados acumulados pelo processo de fotossintese.

Os autores Coombe (1967), Skene (1970) e Lilov e Andanova (1976), comentam que o chlormequat, além de reduzir o crescimento das videiras, favorece a formação de folhas verdes escuras, induzindo o florescimento pelo aumento na produção de citocininas. Nas plantas da Thompson Seedless tratadas com retardadores, foi possivel observar folhas de tonalidade verde mais intensa do que as das plantas controle. Coombe (1970) comenta que a ação retardadora do chlormequat é proporcional a área do ramo tratada, ou seja, existe efeito menor sobre o crescimento dos ramos quando só os ápices são tratados.

O cloreto de mepiquat não mostrou efeito sobre o crescimento dos ramos, inobstante estar sendo utilizado com sucesso em algodão segundo Kerby (1985) em doses inferiores às adotadas neste trabalho.

\subsubsection{Diferença entre comprimento final e inicial dos ramos (CF-CI) e massa da matéria seca (MMS)}

Embora a diferença entre o comprimento final e inicial dos ramos só tenha sido significativa na cultivar Italia, durante o primeiro ciclo, constatou-se, na 'Thompson Seedless', nesse mesmo ciclo, redução de $48 \%$, $32 \%, 8 \%$ e $36 \%$, nos ramos tratados com chlormequat, daminozide, 
uniconazole e cloreto de mepiquat, respectivamente. As plantas da cultivar Thompson Seedless que tiveram menor comprimento de ramos, apresentaram, em conseqüência, menor produção de matéria seca; o mesmo foi constatado no trabalho de Ionescu (1986) que observou um aumento da fotossintese, sem entretanto, conseguir superar o aumento da respiração nas plantas tratadas com chlormequat, havendo então menor acúmulo de matéria seca. Com a cultivar Italia ocorreu o contrário, no dois primeiros ciclos, as plantas tratadas com chlormequat apresentaram menor crescimento dos ramos e maior produção de matéria seca, o que pode ser explicado pela resposta mais efetiva da cultivar ao uso dos retardadores.

\subsubsection{Teor e quantidade acumulada de nutrientes nos ramos}

Os resultados apresentados em teor e quantidade de nutrientes nas duas cultivares avaliadas não foram conclusivos, pois os resultados significativos não se repetiram no correr dos ciclos. Contudo, tanto a 'Italia' como a 'Thompson Seedless', apresentaram valores mais elevados no teor da maioria dos macronutrientes analisados nas plantas tratadas com retardadores do que nas do controle, que só apresentaram teores mais elevados de $\mathrm{P}$ no primeiro ciclo da Italia e $\mathrm{P}$ e $\mathrm{K}$ no segundo ciclo da "Thompson Seedless'. No primeiro ciclo, observou-se que os teores de $\mathrm{N}$ e Ca, na 'Italia', e de todos os macronutrientes, com exceção do $\mathrm{Mg}$, na 'Thompson', foram mais elevados nas plantas tratadas com chlormequat. Plantas com nutrição e aporte hídrico adequado quando tratadas com chlormequat, apresentam aumento no teor de citocininas (Lilov e Andanova, 1976), que por sua vez favorece a translocação de assimilados para órgãos considerados drenos - os cachos florais e, após a colheita, as folhas, os ramos e as raizes (Van Staden e Cook, 1986). Mullins et al. (1992) comentam que as citocininas exercem forte influência sobre a mobilização de assimilados para o local de aplicação, além de promover o desenvolvimento das inflorescências.

Em trabalho realizado por Peacock et al. (1989) com a cultivar Thompson Seedless, as varas podadas apresentaram $9,50 \mathrm{~g} \cdot \mathrm{kg}^{-1} \mathrm{de} \mathrm{N}$, enquanto 
que nesta pesquisa obteve-se teores mais elevados quando foram usados retardadores.

A cultivar Italia demonstrou ser capaz de acumular maior quantidade de nutrientes nas plantas tratadas com chlormequat, apesar de apresentar menor comprimento dos ramos. Esses resultados foram significativos para a quantidade acumulada de $\mathrm{N}$ nos três ciclos avaliados.

Jâ o comportamento da 'Thompson Seedless' foi inverso nos dois primeiros ciclos; sendo as quantidades acumuladas de nutrientes maiores nas plantas controle e nas tratadas com cloreto de mepiquat, não apresentando efeito retardador nos ramos. Entretanto, no terceiro ciclo as plantas tratadas com retardadores foram as que tiveram maior acúmulo dos nutrientes $\mathrm{N}, \mathrm{P}, \mathrm{Ke}$ Ca.

As quantidades acumuladas de $\mathrm{P}, \mathrm{K}$ e $\mathrm{Ca}$ nos ramos das plantas das cultivares Italia e Thompson Seedless foram superiores às encontradas por Conradie (1981) na cultivar Chenin Blanc, em análise dos ramos coletados após a colheita, época também utilizada para coleta no presente trabalho, podendo-se dizer que as plantas em estudo estavam bem supridas de nutrientes, à exceção do $\mathrm{Mg}$, que se apresentou em quantidades acumuladas inferiores.

\subsubsection{Teor e quantidade acumulada de nutrientes nos peciolos}

A análise dos nutrientes nos peciolos da cultivar Italia mostrou que houve um efeito significativo dos retardadores sobre as concentrações de nutrientes nos três ciclos avaliados, com exceção do $\mathrm{K}$ no primeiro ciclo, que foi maior no controle. A concentração de $\mathrm{N}$ aumentou significativamente, no terceiro ciclo, com o uso de Chlormequat (Tabela 4).

Em relação a cultivar Thompson Seedless, houve influência estatisticamente significativa dos tratamentos sobre os teores de $\mathrm{N}$ e $\mathrm{K}$ no primeiro ciclo (Tabela 5), embora as médias de concentração de $\mathrm{P}, \mathrm{Ca}$ e $\mathrm{Mg}$ nas plantas controle tenham sido menores do que nas plantas tratadas, inferindo-se que as doses utilizadas dos retardadores foram insuficientes para causar o desenvolvimento de inflorescências sobre a cultivar. 
Skinner e Matthews (1989) pesquisando o efeito do $\mathrm{P}$ sobre videiras da cultivar Carignane, demonstraram que o desenvolvimento reprodutivo é inibido em condição de baixa suplementação de P. Este fato corrobora na hipótese de que o uso de retardadores seja importante para o desenvolvimento das inflorescências, na medida em que eles favorecem o acúmulo e a concentração do $\mathrm{P}$ e de outros nutrientes nas plantas.

\subsubsection{Produção de paniculas florais}

$\mathrm{Na}$ cultivar Thompson não houve emissão de paniculas florais, entretanto na 'Italia', no decorrer do segundo ciclo as plantas tratadas com chlormequat e uniconazole produziram pequenos cachos florais que se desenvolveram até a plena maturação. No terceiro ciclo, a floração foi mais efetiva: $75 \%$ das plantas tratadas com chlormequat e uniconazole produziram cachos vigorosos e $25 \%$ das tratadas com cloreto de mepiquat produziram cachos de tamanho mediano. Em comparação com as plantas controle que não emitiram cachos, pode-se dizer que houve uma real alteração no balanço hormonal das videiras 'Italia' tratadas com os referidos compostos químicos, que teriam agido contrariamente a ação das giberelinas e ao crescimento dos ramos de modo a favorecerem a diferenciação de gemas férteis.

Tem sido demonstrado em muitas plantas, inclusive Vitis vinifera, que as citocininas mobilizam em grande intensidade assimilados para o local de aplicação, e vários autores têm sugerido que a regulação dos metabólitos está envolvida no florescimento (Sachs e Hackett, 1976; Sachs, 1977).

Abbot (1986), Karaszewska et al.(1986) e Mullins et al. (1992) comentam sobre a importância do balanço hormonal entre giberelinas e citocininas na indução e formação das gemas florais. Estes mesmos autores relatam a atividade do chlormequat na inibição da sintese das giberelinas e aumento da produção de citocininas, conduzindo as plantas ao florescimento. Rai e Bist (1991), utilizando chlormequat e $\mathrm{SADH}$, ambos na dose de $1000 \mathrm{mg}, \mathrm{L}^{-1}$, obtiveram um aumento na frutificação de pereiras de $154 \%$ e $80 \%$, respectivamente, em relação às plantas não tratadas. 
Neste trabalho não se obteve a produção da paniculas florais nas videiras tratadas com doses de $3000 \mathrm{mg} \cdot \mathrm{L}^{-1}$ de daminozide. No entanto Badawi et al. (1978), citado por Karaszewska et al. (1986), induziram a formação de flores em pereiras com uma marcante redução dos teores de giberelinas nos tecidos das gemas e esporões em decorrência da aplicação de concentrações de daminozide, que variaram entre 1000 a $2500 \mathrm{mg} . \mathrm{L}^{-1}$, consideradas elevadas.

Pelo fato das doses de retardadores utilizadas terem causado efeitos significativos sobre os teores de macronutrientes e induzido ao aparecimento de paniculas florais na cultivar Italia, pensa-se que seja possivel obter resultados significativos com a utilização de doses maiores em aplicação única ou doses menores, em repetidas aplicações, durante um mesmo ciclo na 'Thompson Seedless'.

\subsection{Conclusões}

As experiências relatadas com o uso de retardadores de crescimento, permitem concluir que é possivel reduzir o ritmo de crescimento dos ramos nas plantas de videira das cultivares Thompson Seedless e Italia e favorecer a alteração nos teores de nutrientes de modo a induzir a formação de gemas férteis, prerrogativas exploradas no presente trabalho. 


\section{ABSORÇÃO DE MACRONUTRIENTES POR SEIS PORTA- ENXERTOS E DUAS CULTIVARES DE VIDEIRA EM CONDIÇÕES DE HIDROPONIA}

\subsection{Resumo}

A proposta deste trabalho foi detectar a capacidade de absorção de macronutrientes em alguns porta-enxertos de possivel utilização para a cultivar Thompson Seedless, estabelecendo as melhores correlações. Os portaenxertos: Tropical - IAC 313, Jales - IAC 572, Campinas - IAC 766, Dog Ridge, Salt Creek e Harmony; e as produtoras: Italia e Thompson Seedless foram propagados por estacas de 2 gemas, colocadas para enraizar em areia grossa lavada até desenvolverem raizes suficientes que permitissem o transplante para recipientes de $3 \mathrm{~L}$ de volume, contendo 2 partes de silica e 1 parte de areia grossa. Nessa ocasião as mudas foram uniformizadas através de poda, tanto do sistema radicular como da parte aérea. A solução nutritiva foi preparada segundo Furlani (1995), sendo aplicada por irrigação em sistema fechado de gotejamento, acionado por temporizador. Quando as plantas apresentavam, em média, um ramo com aproximadamente $1,50 \mathrm{~m}$ de comprimento, foi realizada a poda do sistema aéreo. Após moagem do material seco, as amostras foram analisadas quanto ao teor de macronutrientes conforme metodologia descrita em Sarruge e Haag (1974). Os resultados obtidos foram submetidos à análise estatistica através do programa SAS, realizando-se a análise de variância e o teste Tukey, ao nivel de $5 \%$ de probabilidade, para as médias. A análise dos dados permitiu concluir que: as cultivares Jales e Tropical são os mais vigorosos porta enxertos entre os testados; a quantidade de nutrientes acumulados é proporcional a produção de biomassa; a produção de biomassa 
das produtoras Thompson Seedless e Italia mostra-se inferior ao do porta-enxerto Jales; as cultivares Thompson Seedless e Italia apresentam capacidade de absorção de nutrientes semelhante aos dos porta-enxertos de baixo e médio vigor.

\subsection{Summary}

The purpose of this study was establish the macronutrients uptake capacity of some rootstocks to Thompson Seedless cv. with the best correlations. Rootstochs: Tropical - IAC 313, Jales - IAC 572, Campinas - IAC 766, Dog Ridge, Salt Creek e Harmony; and Italia and Thompson Seedless cultivars was propagated from two buds cuttings in sand until roots development when the plants were transplanted into $3 \mathrm{~L}$ pots with a mixing 2:1 volume of silica and sand. The young grapevines were pruned for homogeneous size. The growth solution was prepared according to Furlani (1995) supplied by a dropping system. The pruning was made when the grapevines shoots were $1,50 \mathrm{~m}$. The samples were dried and analyzed following Sarruge e Hagg (1974). The results were analyzed by SAS statistic program and it was indicated that: Jales and Tropical rootstock were more vigorous than the others; the macronutrients uptake was relative to the biomass production; Thompson Seedless and Italia grapevines biomass production were lesser than jales rootstock; Thompson Seedless and Italia macronutrientes uptake were such as weakly and midle vigour rootstock.

\subsection{Introdução}

Estudos recentes feitos por Casucci (1995) colocam em evidência o interesse do mercado mundial por uvas apirenicas, dando especial destaque para a 'Thompson Seedless', cultivar sem sementes que apresenta, entretanto, uma adaptação climática limitada a poucas áreas no mundo (Califórnia nos Estados Unidos, região norte do Chile, África do Sul, Israel e algumas outras áreas da região mediterrânea) em função da necessidade de condições especiais de temperatura, intensidade luminosa, fotoperiodo e nutrição mineral para que se efetue o processo de diferenciação das gemas vegetativas em gemas mistas com primórdios de ramo e de cacho floral. 
Em condições de clima tropical essa cultivar apresenta-se excessivamente vigorosa, com uma vegetação muito densa em detrimento do desenvolvimento de inflorescèncias, ficando a produção por planta resumida a poucos cachos que apresentam peso inferior a $300 \mathrm{~g}$. A insuficiente diferenciação das gemas latentes, que resulta na baixa fertilidade das mesmas é ainda mais acentuada quando a 'Thompson Seedless' é enxertada no portaenxerto 'Tropical' (IAC 313), dando origem a plantas excessivamente vigorosas com ramos que chegam a crescer quase dez metros de comprimento num periodo de quatro meses. Em trabalho que avaliou o comportamento da cultivar sobre os porta-enxertos 'Tropical', 'Harmony', 'Salt Creek' e 'Dog Ridge' na região do Submédio São Francisco, Freire et al. (1991), obtiveram maiores produções por planta e peso médio dos cachos com o uso dos porta-enxertos 'Harmony' e 'Salt Creek', embora as plantas mais vigorosas tenham sido aquelas desenvolvidas sobre o porta-enxerto 'Tropical'.

Os porta-enxertos apresentam grande variação em vigor, em conseqüência das diferentes exigèncias nutricionais e capacidade de absorção de água e nutrientes, pois suas raizes apresentam seletividade na absorção de ions da solução do solo (Iannini, 1984). A utilização de porta-enxertos em viticultura tem como objetivos aumentar ou diminuir o vigor das plantas enxertadas, melhorar a produção e qualidade dos frutos e alterar, em algumas cultivares, a época de maturação destes; alêm de controlar o ataque de pragas de solo, tais como filoxera, nematóides e pérola-da-terra.

Zimmermann (1986), analisando os resultados de um trabalho com vários cultivares e porta-enxertos, chegou a conclusão que não existe um porta-enxerto universalmente apropriado e que cada cultivar exige um porta-enxerto particular para apresentar compatibilidade e adaptação ótimas. Uma compatibilidade ideal entre porta-enxerto e cultivar produtora deve tender à obtenção de vinhedos onde se realize a máxima utilização dos nutrientes da solução do solo, com maior eficiência físiológica da parte aérea, havendo um perfeito equilibrio entre crescimento vegetativo e reprodutivo. Para Keller e Koblet (1995) a capacidade de crescimento vegetativo apresenta alta correlação com os niveis de nutrientes armazenados, principalmente, $\mathrm{C}$ e $\mathrm{N}$, ficando 
comprovado que o crescimento e o desenvolvimento das plantas são essencialmente dependentes da eficiència do sistema radicular em absorver e translocar nutrientes minerais para o sistema aéreo, assim como, da sua aptidão para armazenar substāncias de reserva.

Pondera-se que através do uso de um porta-enxerto adaptado às condiçōes tropicais poder-se-ia favorecer a distribuição de nutrientes e o balanço hormonal em videiras da cultivar Thompson Seedless, obtendo-se plantas equilibradas, sem grande crescimento vegetativo e com maior número de gemas férteis. A proposta deste trabalho foi detectar a capacidade de absorção de macronutrientes em alguns porta-enxertos de possivel utilização para as cultivares Italia e Thompson Seedless, estabelecendo as melhores correlaçōes.

\subsection{Material e métodos}

\subsubsection{Localização do experimento}

O experimento foi desenvolvido sob condições de hidroponia em casa-devegetação localizada no Setor de Nutrição Mineral de Plantas, Departamento de Química da Escola Superior de Agricultura "Luiz de Queiroz" da Universidade São Paulo, em Piracicaba (SP). A cidade de Piracicaba encontra-se a $22^{\circ} 42^{\prime}$ de latitude S e $47^{\circ} 38^{\prime}$ de longitude $\mathrm{W}$ e a $515 \mathrm{~m}$ de altitude. A região é caracterizada por um clima tropical de altitude. Durante a realização do experimento de 22 de julho a 4 de outubro de 1997, as temperaturas diurnas oscilaram entre $30^{\circ} \mathrm{C}$ e $46^{\circ} \mathrm{C}$ e as noturnas, entre $11^{\circ} \mathrm{C}$ e $23^{\circ} \mathrm{C}$.

\subsubsection{Delineamento experimental}

O experimento foi realizado em blocos, ao acaso, com oito tratamentos (seis porta-enxertos e duas produtoras) e cinco repetições. As parcelas eram constituidas por duas plantas, tendo-se um total de oitenta vasos cada um com uma planta. 


\subsubsection{Cultivares utilizados}

\section{- Porta-enxertos}

\section{- Tropical - IAC 313}

Descrição obtida em Pommer (1993).

Origem - cruzamento do porta-enxerto 'Golia' com a espécie de videira tropical Vitis cinerea realizado no I.A.C. e liberado para cultivo em 1955.

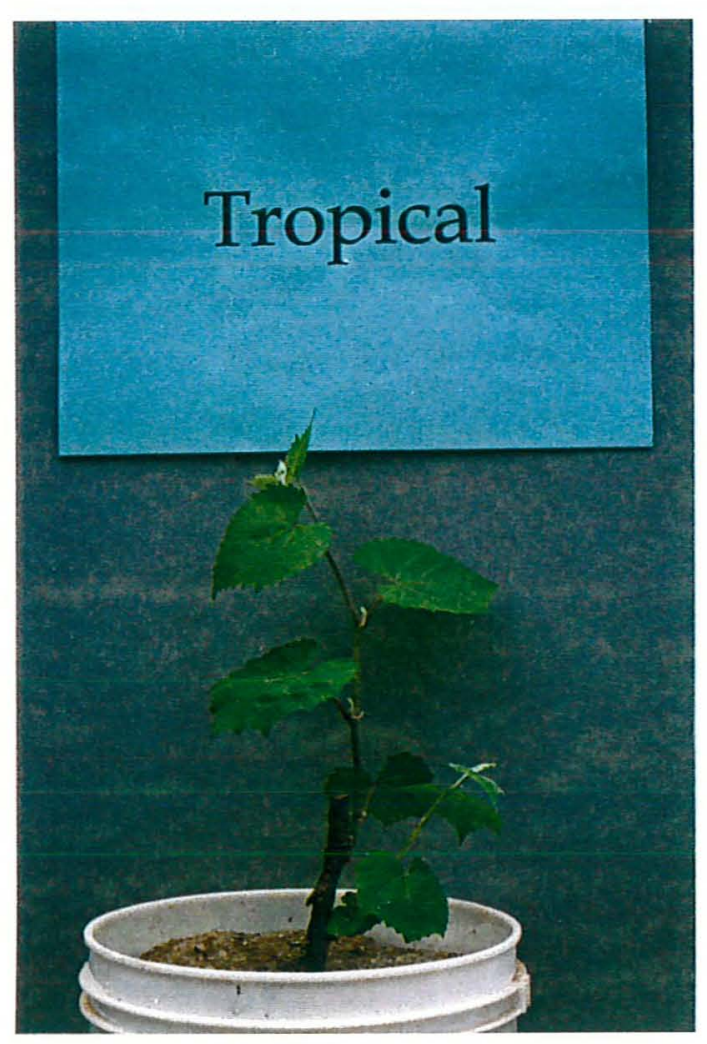

Figura 11. Brotações da cv. Tropical no início do crescimento.

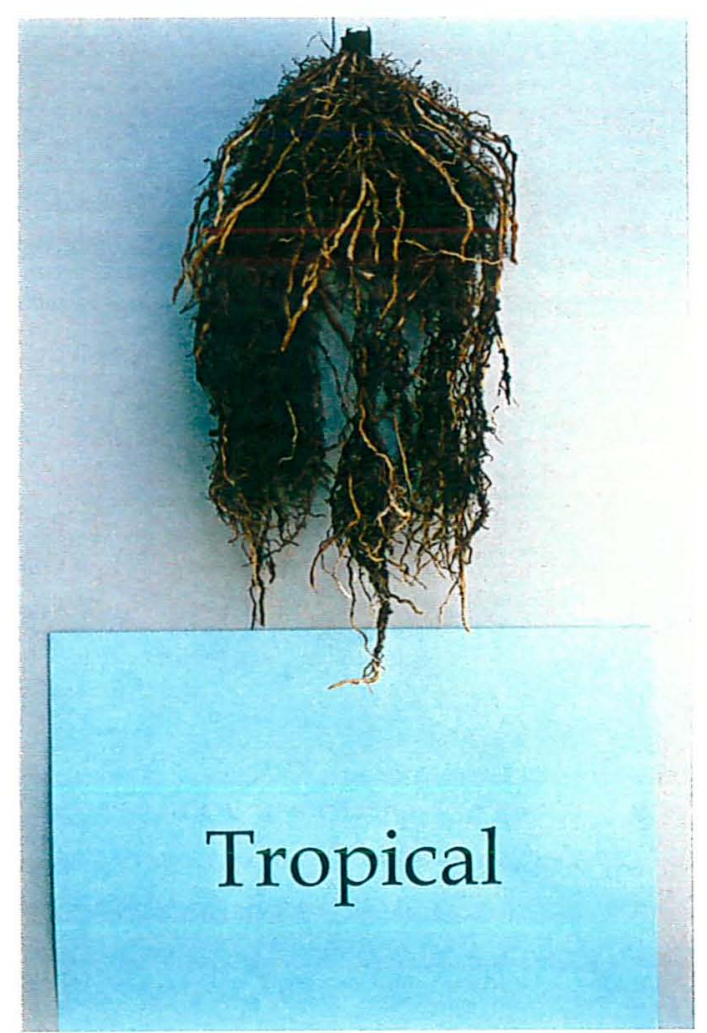

Figura 12. Crescimento do sistema radicular da cv. Tropical.

Características de identificação - pecíolo $(5 \mathrm{~cm})$ verde claro ou levemente bronzeado, com pilosidade pronunciada brancacenta e lanuginosa ao longo dos vértices e junto a inserção da lâmina foliar. Lâmina foliar $(7,5$ x 8,6 cm) verdeescura na parte superior e sem pigmentação antociânica e mais clara e opaca na inferior, pilosidade lanuginosa pronunciada na face superior e abundante na inferior. As duas nervuras primárias basais são muito curtas e logo se ramificam. As folhas apresentam em média, cinco dentes primários, 21 
secundários e 24 terciários. Folhas com lobos curto-acuminados e base reentrante e subcordada. Broto terminal verde-claro, bronzeado, com pilosidade branca e lanuginosa sobre ramos e folhas jovens. Estipulas curtas (1 $\mathrm{mm}$ ), bronzeadas e pilosas. Gavinhas verde-claras, branco-lanuginosas ou glabras na base.

Caracteristicas agronômicas - é um porta-enxerto vigoroso, com perfeita adaptação às condições climáticas tropicais e a diferentes tipos de solos. Suas folhas apresentam boa resistência às doenças e dificilmente caem, e seus ramos têm uma lenta lignificação. Apresenta bom indice de pegamento das estacas, com formação de mudas vigorosas. Adaptado para diversas cultivares produtoras ('Italia', 'Piratininga', 'Red Globe').

\section{. Jales - IAC 572}

Descrição obtida em Pommer (1993).

Origem - cruzamento entre Vitis caribea e o porta-enxerto 'RR 101-14' realizado em 1955 no I.A.C.

Caracteristicas de identificação - peciolo $(4,7 \mathrm{~cm})$ vermelho-escuro ou bronzeado, opaco e, ao longo dos vértices, com pelos simples curtos e pelos lanuginosos, ambos brancos, pilosidade mais concentrada junto ao seio peciolar. Lâmina foliar $(12,1 \times 12,7 \mathrm{~cm})$ verde-escura na face superior e verdeclara e opaca na inferior, coberta com uma pilosidade curta e branca nas duas faces. Nervuras primárias e secundárias, bem como o seio peciolar, pigmentados de antocianina, particularmente na base. Folhas em média com cinco dentes primários, 29 secundários e 31 terciários. Os lobos correspondentes às très nervuras primárias centrais são bem desenvolvidos, apresentando-se a folha nitidamente trilobada. Os brotos terminais são verdesclaro ou levemente bronzeados. As folhas e os brotos jovens são densamente recobertos por uma pilosidade lanuginosa. As estipulas (1mm) são precocemente caducas, castanho-bronzeadas e pilosas. Gavinhas de coloração avermelhada variável, com pelos esparsos e simples, curtos ou lanuginosos, brancos. 


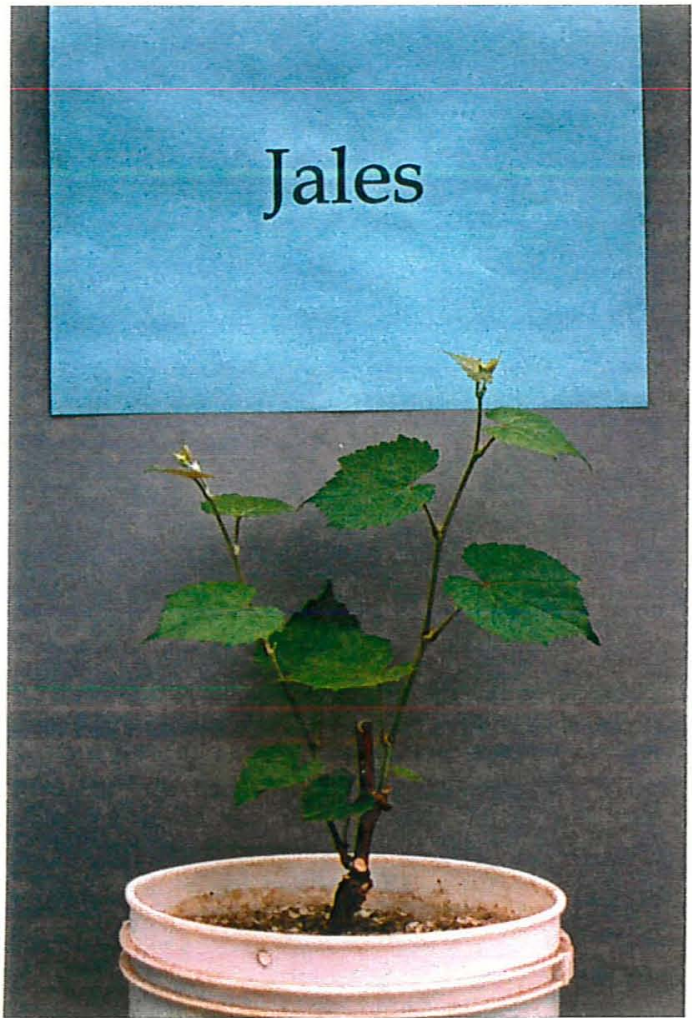

Figura 13. Brotações da cv. Jales no início do crescimento.

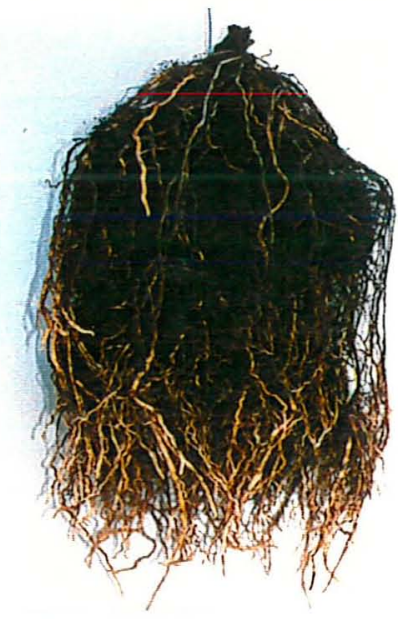

\section{Jales}

Figura 14. Crescimento do sistema radicular da cv. Jales.

Caracteristicas agronômicas - cultivar vigoroso, adaptando-se bem quer em solos argilosos, quer em arenosos. Apresenta folhas resistentes às principais moléstias. A formação de mudas é excelente, tanto no enraizamento, como no pegamento. Tem-se destacado como ótimo porta-enxerto para cultivares de mesa, tais como 'Italia', 'Rubi', 'Red Globe' e 'Centennial Seedless'.

\section{. Campinas - IAC 766}

Descrição obtida em Pommer (1993).

Origem - cruzamento entre 'Ripária do Traviu' e a espécie de videira tropical Vitis caribea obtido no I.A.C. em 1958.

Características de identificação - pecíolo $(5,6 \mathrm{~cm})$ de coloração verde levemente amarelada, pela pigmentação antociânica, com estrias mais escuras e esparsos pelos simples ao longo dos vértices. Lâmina foliar $(8,2 \times 10,7 \mathrm{~cm})$ verde escura na face superior e levemente mais clara na inferior. Nervuras primárias com leve pigmentação de antocianina, com pelos simples, hialinos e 
bem curtos, e alguns pelos lanuginosos; essa pilosidade ocorre em ambas as faces. As folhas apresentam, em média, cinco dentes primários, 19 secundários e 18 terciários. Lobos foliares pouco nítidos e base foliar bem fechada com bordos quase sobrepostos. Broto terminal bronzeado ou verdebronzeado, com abundantes pelos simples, curtos e pelos lanuginosos, ambos brancacentos. Estipulas $(2,5 \mathrm{~cm})$ lanceoladas, de ápice agudo ou ovaladas, bronzeadas e pilosas. Gavinhas avermelhadas, cilindricas, glabras e levemente reluzentes.

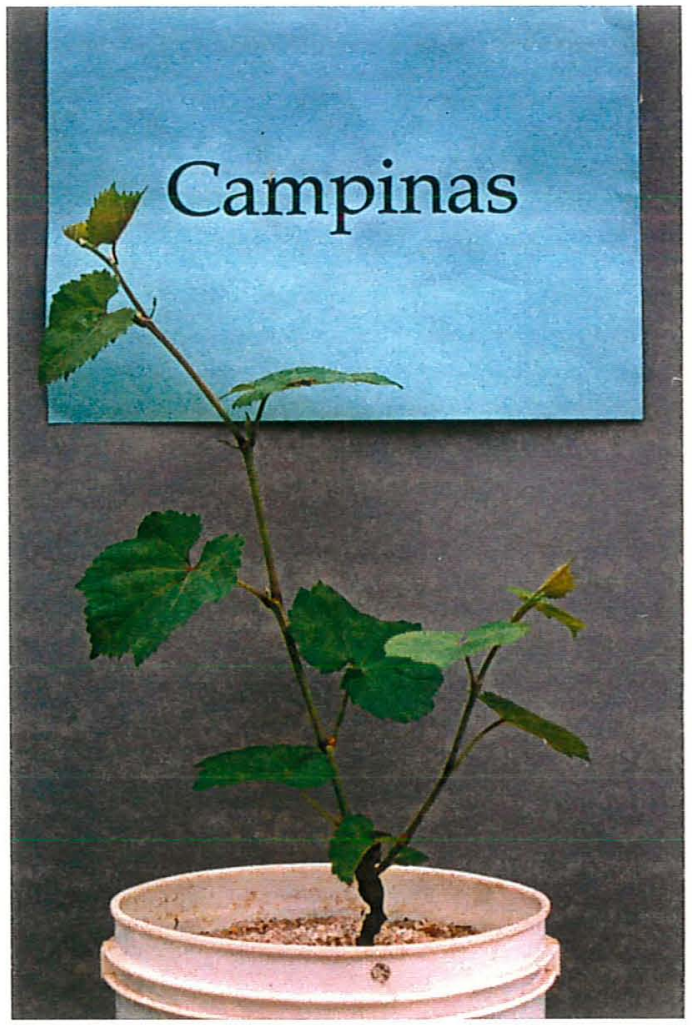

Figura 15. Brotações da cv. Campinas no início do crescimento.

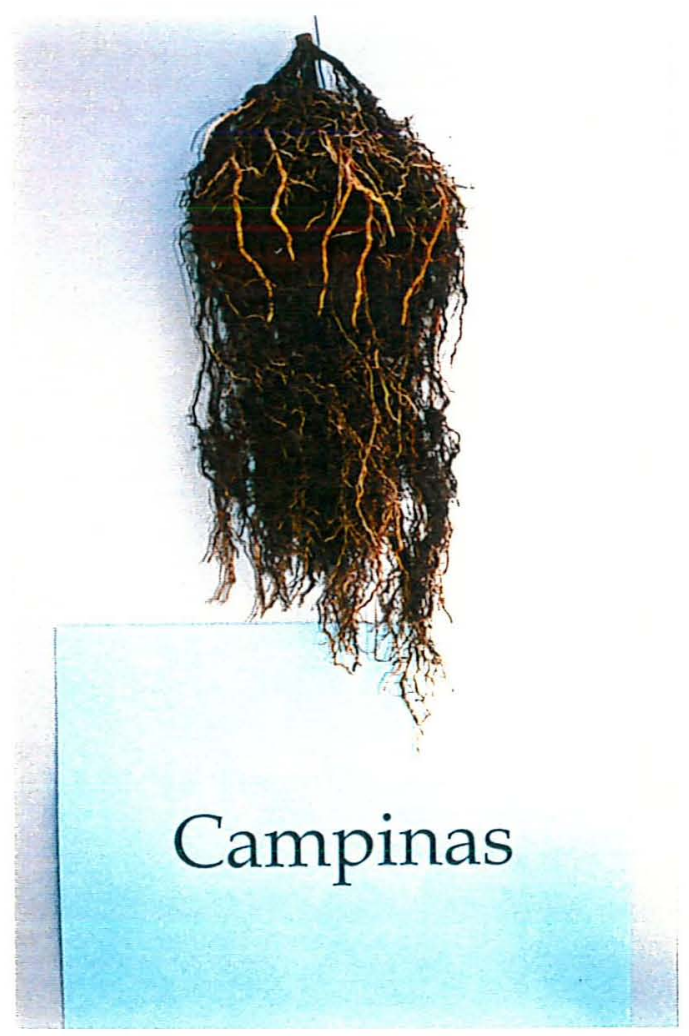

Figura 16. Crescimento do sistema radicular da cv. Campinas.

Características agronômicas - porta-enxerto vigoroso com ótima adaptação às condições de clima tropical. Suas folhas são resistentes às principais doenças e seus ramos hibernam melhor que os do 'Tropical'. Apresenta bom pegamento das estacas. É um porta-enxerto compativel com muitas cultivares produtoras, entre elas: 'Italia', 'Rubi', 'Benitaka', 'Red Globe', 
'Centennial Seedless', 'Patrícia', 'Maria', 'Paulistinha', 'Niagara', 'Máximo' (IAC 138-22).

\section{- Dog Ridge}

Descrição obtida em Sousa (1996).

Origem - é uma variedade de Vitis champini, espécie resistente a nematóides, nativa do centro-norte do Texas.

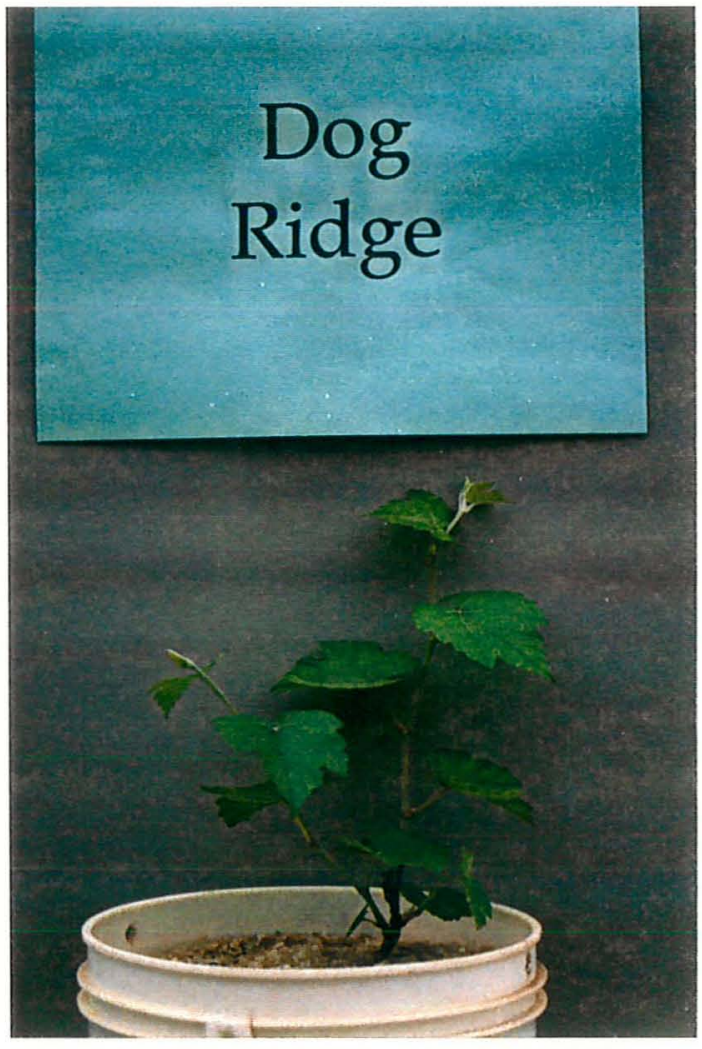

Figura 17. Brotações da cv. Dog Ridge no início do crescimento.

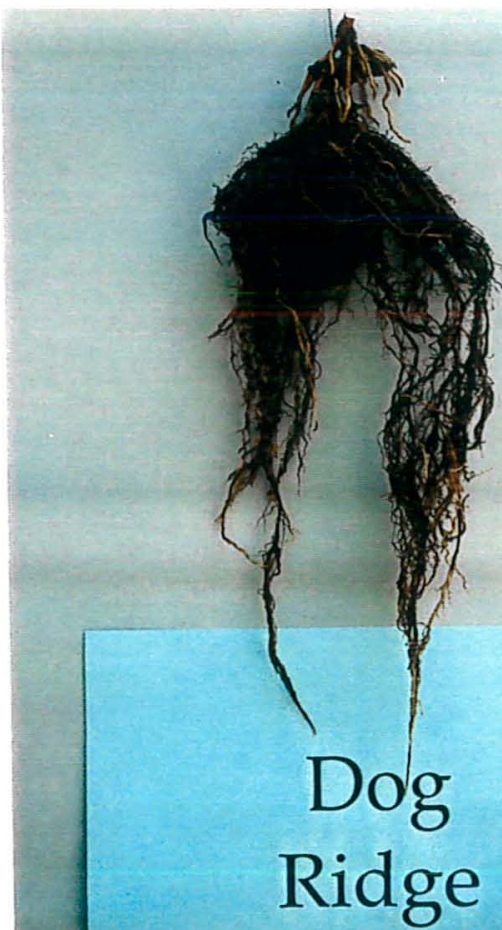

Figura 18. Crescimento do sistema radicular da cv. Dog Ridge.

Características de identificação - folhas médias de coloração verde médio, com 3 a 5 lóbulos, moderadamente distintos. Face superior recoberta com longos pelos e inferior com moderada pubescência, concentrada sobre as nervuras e peciolos. Bordas com serrilhado estreito. Cavidade peciolar profunda, aberta e em forma de "V". Os ramos são vigorosos com longos internós. Os ápices são esbranquiçados cobertos de pubescência. As gavinhas são longas e vigorosas, bifurcadas e de coloração púrpura. As plantas são 
muito vigorosas, espalhadas e de hábito prostrado. Produz flores femininas que desenvolvem cachos pequenos e compactos de bagos pretos.

Características agronômicas - este porta-enxerto confere grande vigor aos enxertos. É resistente a nematóides. Freqüentemente apresenta sintomas de deficiência de zinco. É recomendado para plantio em solos mais leves, de pouca fertilidade e arenosos. As estacas enraizam com dificuldade, porém brotam facilmente, emitindo muitos rebentos.

\section{- Salt Creek}

Descrição obtida em Sousa (1996).

Origem - tem a mesma origem do 'Dog Ridge', sendo uma variedade de Vitis champini, não devendo, entretanto, ser confundido com este.

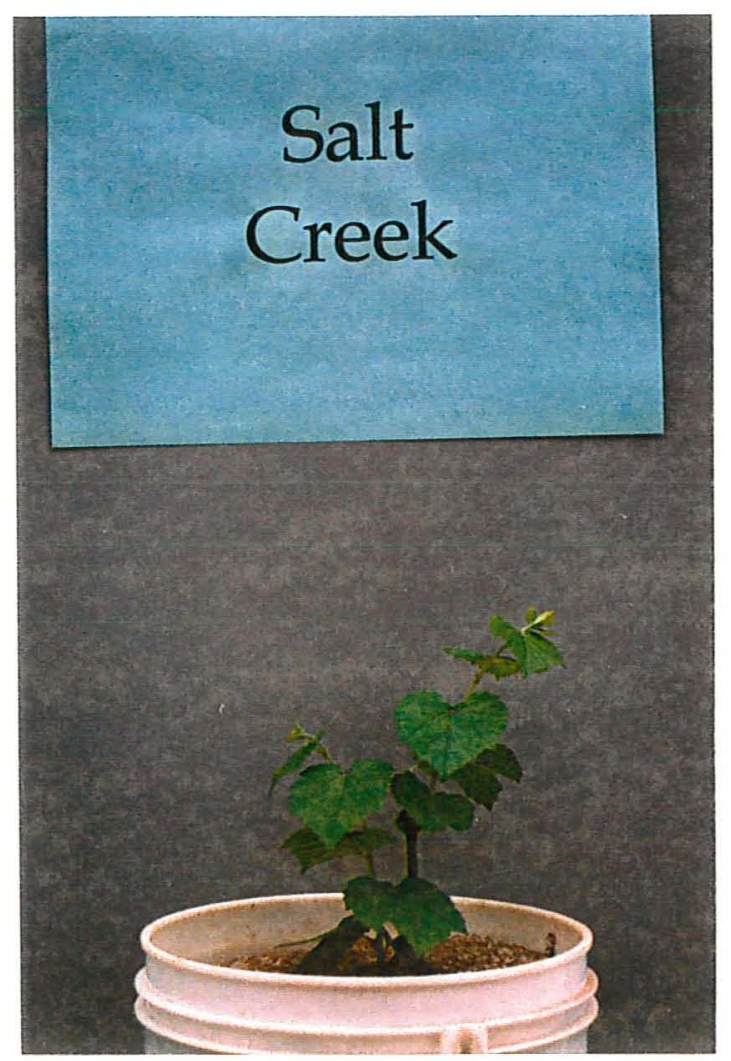

Figura 19. Brotações da cv. Salt Creek no início do crescimento.

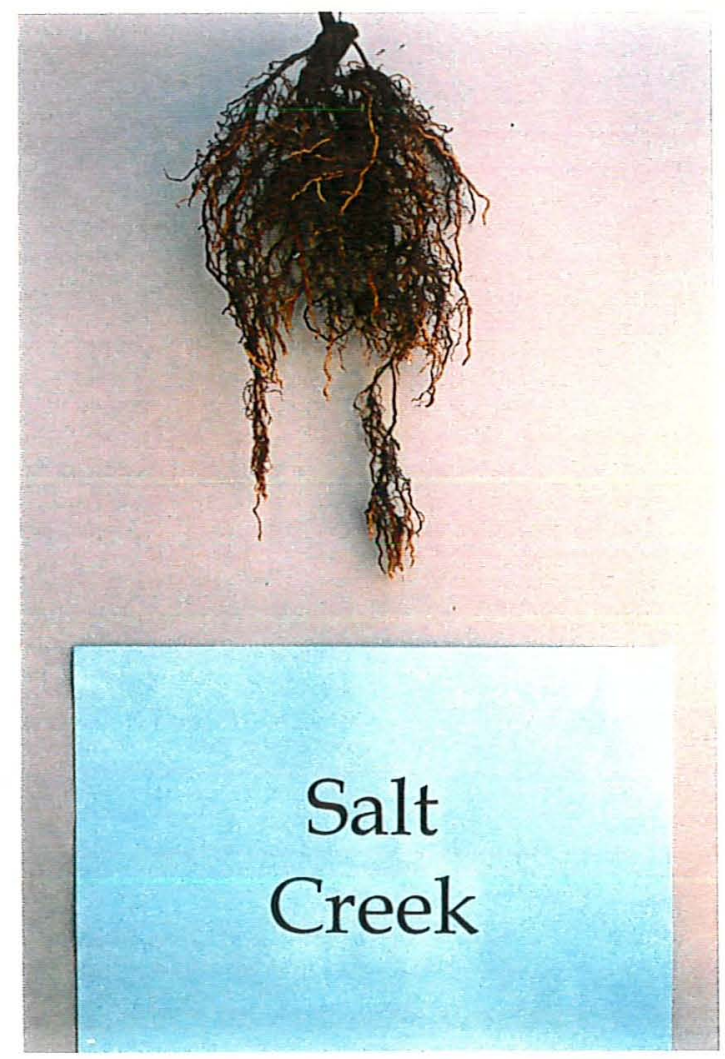

Figura 20. Crescimento do sistema radicular da cv. Salt Creek.

Caracteristicas de identificação - as folhas são de médias a pequenas, com três lóbulos pouco distintos e arredondados, possuindo coloração verde 
médio com um brilho fosco. As bordas apresentam um serrilhado uniforme e estreito. Cavidade peciolar profunda, aberta e em forma de "U". Tanto a face superior das folhas como a inferior apresentam-se recobertas por uma leve pubescência. Os ramos apresentam crescimento moderadamente vigoroso e ereto, com internós de tamanho médio. Os ápices são moderadamente pubescentes, de cor verde-amarelada. Gavinhas pequenas ou médias, de cor verde-amarelada e bifurcadas.

Características agronômicas - plantas moderadamente vigorosas e resistentes a nematóides. É um porta-enxerto adequado para cultivares de passa e de vinho. Enraiza com dificuldade, mas viceja com facilidade, apresentando brotações laterais.

\section{- Harmony}

Descrição obtida em Sousa (1996).

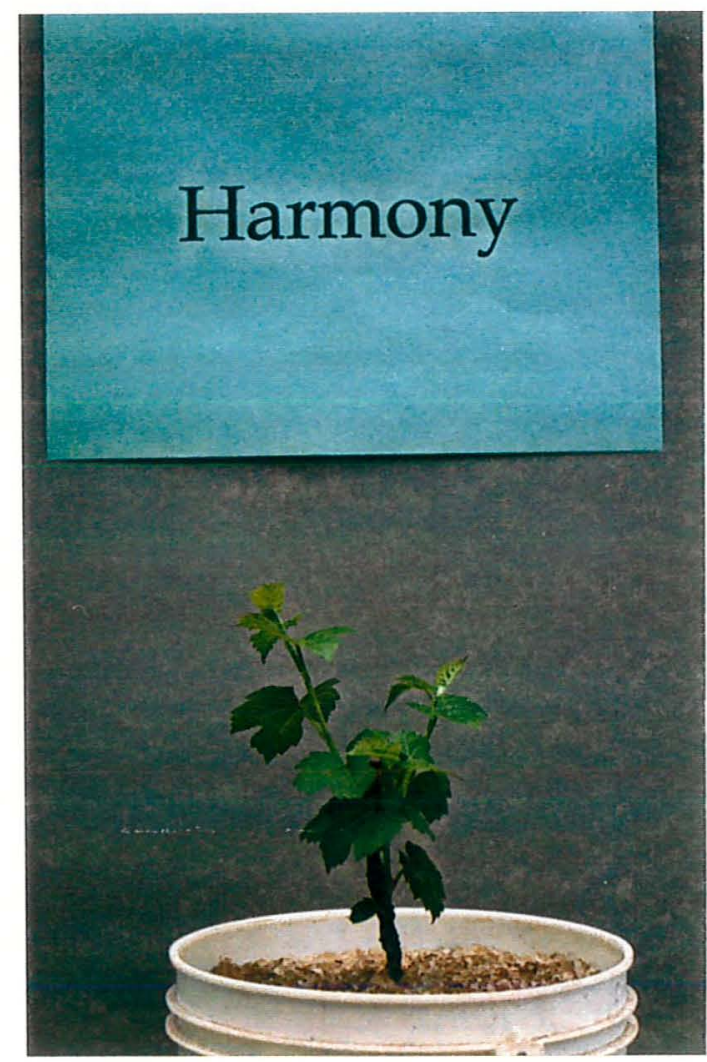

Figura 21. Brotações da cv. Harmony no início do crescimento.

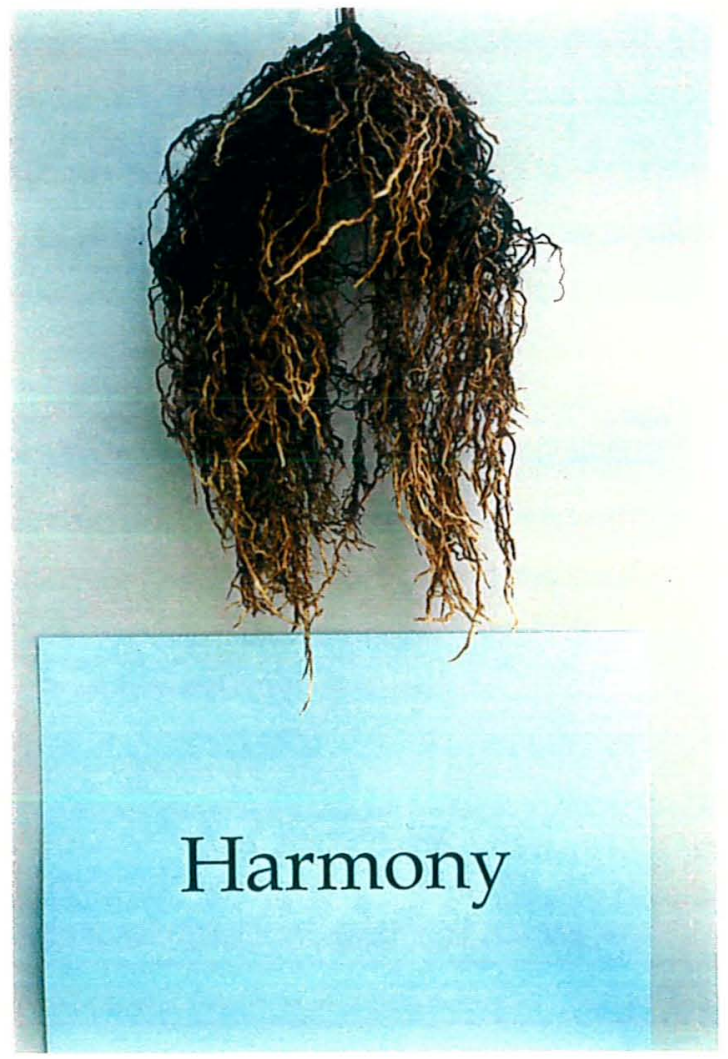

Figura 22. Crescimento do sistema radicular da cv. Harmony. 
Origem - resultante do cruzamento entre 'Couderc 1613' (Solonis $\mathrm{x}$ Othello) e 'Dog Ridge', obtido em 1955 na U.S. Horticultural Field Station, em Fresno, Califórnia.

Características de identificação - folhas de tamanho médio a pequeno de coloração verde e brilhosa, com três lóbulos pouco distintos e de forma arredondada. Bordas com um serrilhado estreito, distinto e irregular. Cavidade peciolar profunda, em forma de "U", pouco pronunciado. Face superior e peciolos com uma leve pubescência de cor cinza. Face inferior com poucos pelos. Peciolos longos. Ramos com internós moderadamente vigorosos e de tamanho médio. Ápices com pouca pubescência. Gavinhas pequenas $\mathrm{e}$ bifurcadas.

Caracteristicas agronômicas - as plantas enxertadas sobre o 'Harmony' são menos vigorosas do que as enxertadas sobre 'Dog Ridge' e 'Salt Creek'. Mostra-se particularmente adequado para a cultivar Thompson. É resistente aos nematöides das galhas. Estacas desta cultivar brotam e enraizam com facilidade, adaptando-se bem a solos não muito leves.

\section{. Cultivares produtoras}

\section{Italia}

Descrição obtida em Sousa (1996).

Origem - resultante do cruzamento entre 'Bicane' e 'Moscatel de Hamburgo', realizado em 1911, na Itália.

Caracteristicas de identificação - as folhas são de médias a grandes, com cinco lóbulos, forma orbicular, com seio peciolar em lira estreita, às vezes fechado. O limbo apresenta textura média com face inferior revestida de pubescência, de coloração verde intensa. Gavinhas bifurcadas finas. Cachos grandes, de forma cilindro-cônicos. Bagos grandes, elipsóides, amarelosdourados, quando bem maduros, de textura crocante e sabor levemente moscato. Película mediana.

Caracteristicas agronômicas - plantas relativamente vigorosas com entrenós medianos. Exigem poda média com varas de seis a oito gemas. As 
plantas dessa cultivar são muito produtivas, mesmo sob as condições tropicais do Nordeste do Brasil.

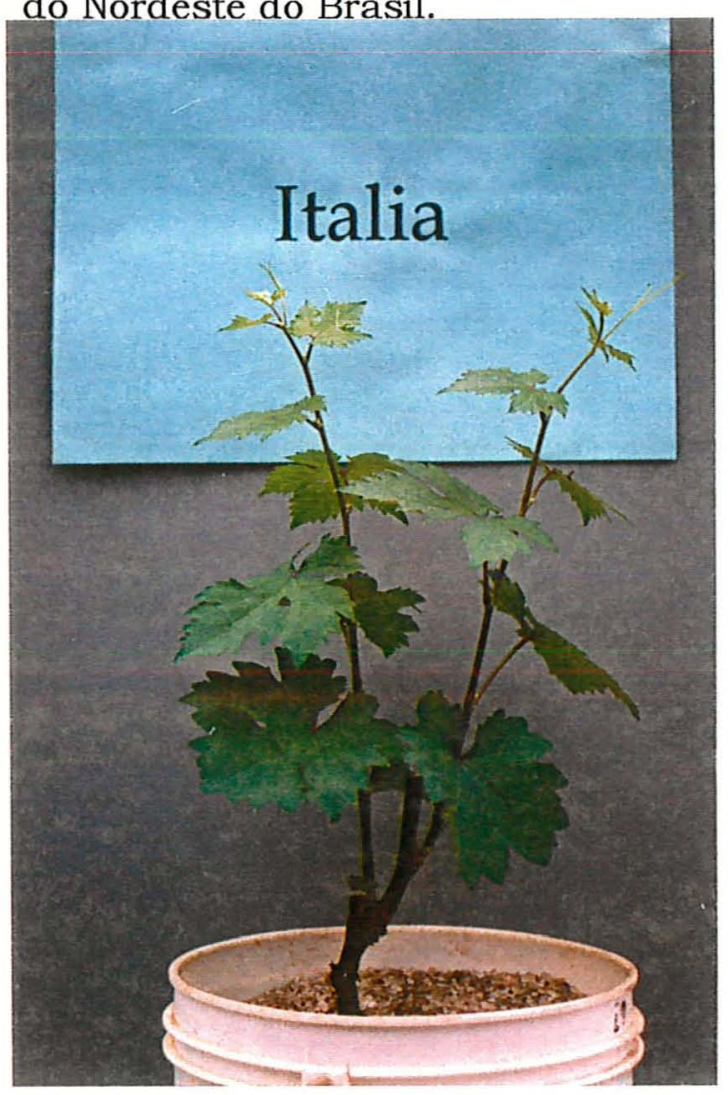

Figura 23. Brotações da cv. Italia no início do crescimento.

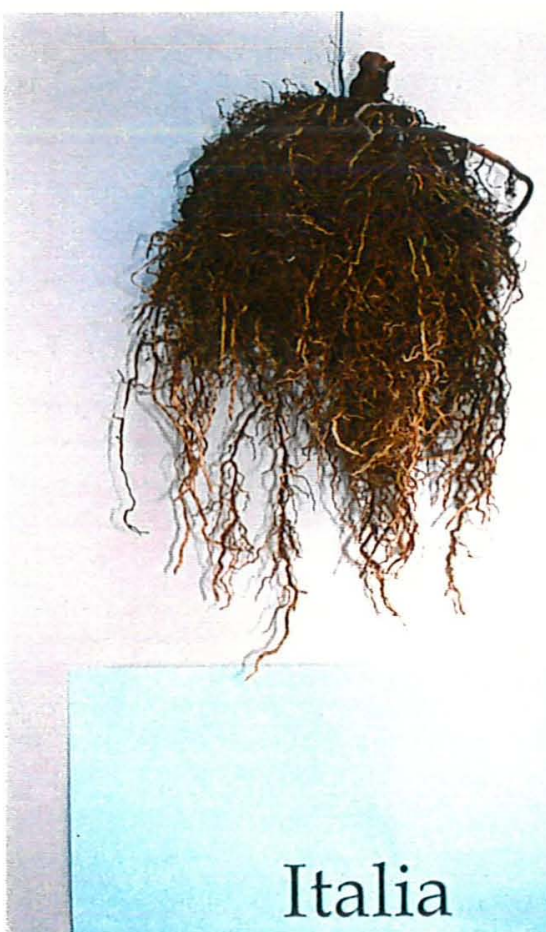

Figura 24. Crescimento do sistema radicular da $\mathrm{cv}$. Italia.

\section{. Thompson Seedless}

Origem - cultivar muito antiga originada da Ásia Menor (região da Turquia), de onde foi levada para a Pérsia e Grécia, adaptando-se perfeitamente nesses paises.

Características de identificação - folhas variando de médias para grandes, inteiras ou vagamente trilobadas, orbiculares. Limbo fino com as duas faces glabras, levemente ondulado, de coloração verde clara. Seio peciolar em lira com bordos sobrepostos. Ramos herbáceos glabros, verde amarelados com tons rosados na altura dos nós. Gavinhas grossas de cor amarelada. Cachos grandes, ramosos, compactos, de formato cilindro-cônico. Bagos elipsóides alongados, de tamanho pequeno e coloração branca-verdosa a 
amarela dourada. Polpa de textura crocante, sem sementes, sabor neutro e muito doce quando atinge a plena maturação. Película medianamente espessa.

Características agronômicas - planta muito vigorosa, com ramos muito longos; entrenós de comprimento médio a longo, com ramificações fortes e numerosas. Plantas de produção média a baixa, exigindo poda longa com varas de 10 a 15 gemas. São muito sensiveis às doenças fúngicas: míldio e oídio.

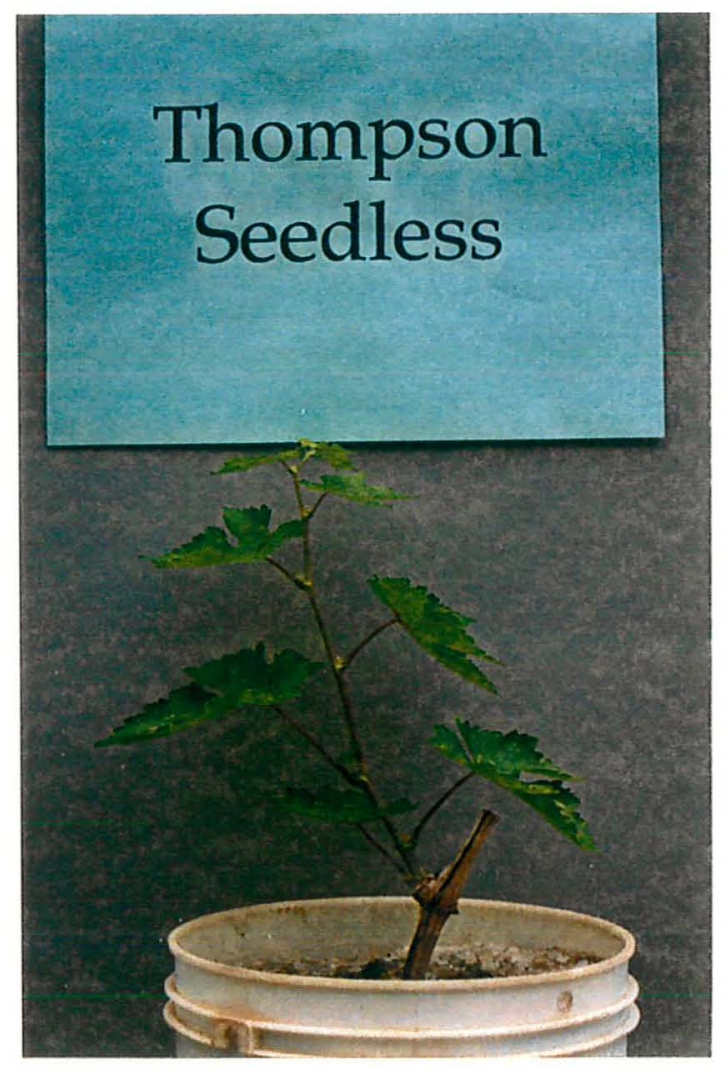

Figura 25. Brotações da cv. Thompson Seedless no início do crescimento.

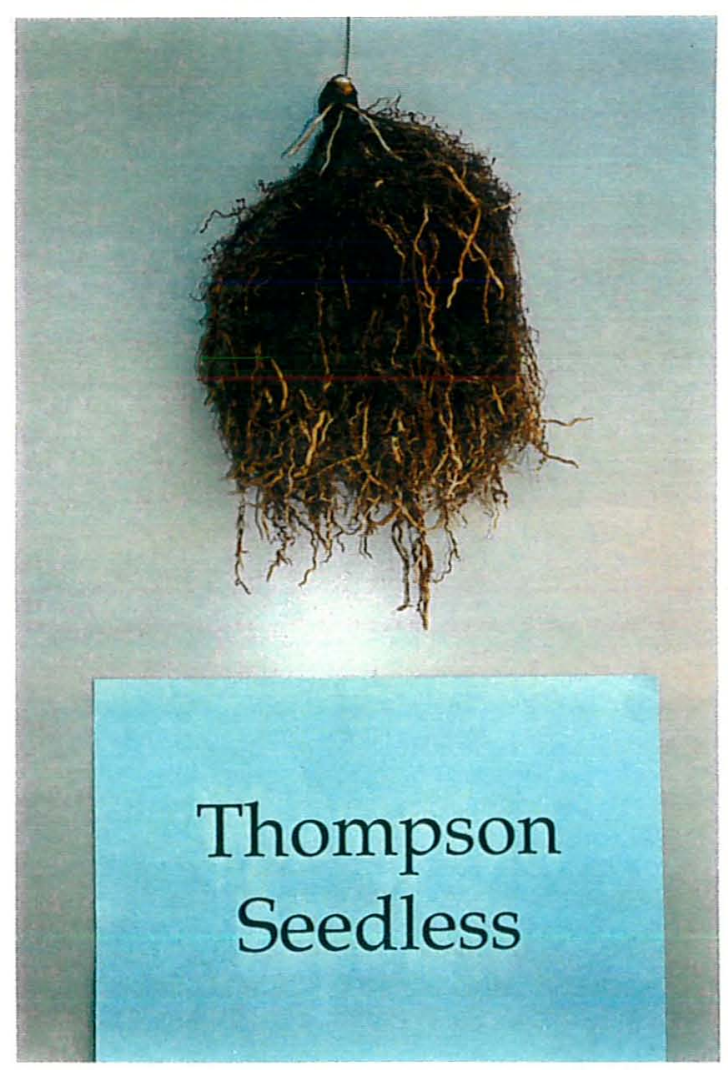

Figura 26. Crescimento do sistema radicular da cv. Thompson Seedless.

\subsubsection{Condução do experimento}

\section{- Preparo das mudas}

Os porta-enxertos e as produtoras foram propagados por estacas semi-lenhosas de 2 gemas, colocadas para enraizar em areia grossa lavada até desenvolverem raizes suficientes que permitissem o transplante para recipientes de $3 \mathrm{~L}$ de volume contendo 2 partes de sílica e 1 parte de areia 
grossa. Nessa ocasião as mudas foram uniformizadas através de poda, tanto do sistema radicular como da parte aérea.

\section{. Solução nutritiva}

A solução nutritiva foi preparada em um tanque de $250 \mathrm{~L}$ de volume com adubos químicos, baseada na recomendação de Furlani (1995) para a cultura da alface, tendo a seguinte composição por litro: $1,0 \mathrm{~g}$ de nitrato de cálcio; $0,8 \mathrm{~g}$ de nitrato de potássio; $0,15 \mathrm{~g}$ de cloreto de potássio; $0,15 \mathrm{~g}$ de fosfato de monoamônio; $0,25 \mathrm{~g}$ de sulfato de magnésio. Adicionou-se, ainda, $1,0 \mathrm{~mL}$ da solução de micronutrientes e 1,2mL da solução de Fe-EDTA por litro de solução. Nesta solução é possivel, através da relação de nitrato $\left(\mathrm{NO}_{3}^{-}\right)$e amônia $\left(\mathrm{NH}_{4}{ }^{+}\right)$na razão de 9:1, ter-se um adequado controle do pH (Jones, 1983), evitando-se possiveis problemas com a deficiência de micronutrientes, que soe acontecer quando da utilização da solução de Hogland e Arnon, em que só o nitrato é usado como fonte de $\mathrm{N}$.

Tabela 4. Concentrações de macronutrientes na solução hidropônica.

$\begin{array}{llllllll}\text { Nutrientes } & {\mathrm{N}-\mathrm{NO}_{3}-}^{-} & \mathrm{N}^{-\mathrm{NH}_{4}{ }^{+}} & \mathrm{P} & \mathrm{K} & \mathrm{Ca} & \mathrm{Mg} & \mathrm{S}_{-\mathrm{SO}_{4}}^{-} \\ \text {Conc. }\left(\mathrm{mg} \mathrm{L}^{-1}\right) & 223 & 26,5 & 32 & 294 & 190 & 24 & 33\end{array}$

A concentração de nutrientes da solução nutritiva utilizada neste trabalho (Tabela 4) é semelhante àquela em uso há 20 anos na Station de Recherches de Viticulture em Bordeaux, segundo Pouget (1984), sendo possivel obter plantas vigorosas aptas a frutificar a partir do 2 o ciclo vegetativo, em cultivos hidropônicos, quando se utiliza tal solução.

A solução de micronutrientes utilizada foi a preconizada por Hogland e Arnon (1950) e foi preparada com a seguinte composição: $\mathrm{H}_{3} \mathrm{BO}_{3}-2,86 \mathrm{~g}$; $\mathrm{MnCl}_{2} \cdot 4 \mathrm{H}_{2} \mathrm{O}-1,81 \mathrm{~g} ; \quad \mathrm{ZnSO} \mathrm{Z}_{4} .7 \mathrm{H}_{2} \mathrm{O}-0,22 \mathrm{~g} ; \mathrm{CuSO}_{4} \cdot 5 \mathrm{H}_{2} \mathrm{O}-0,08 \mathrm{~g} ; \mathrm{H}_{2} \cdot \mathrm{MoO}_{4} \cdot \mathrm{H}_{2} \mathrm{O}-$ $0,02 \mathrm{~g}$ (com $85 \%$ de $\mathrm{MoO}_{3}$ ) dissolvidos em um litro de agua destilada $\mathrm{e}$ desmineralizada. O ferro foi adicionado através de uma solução de Fe-EDTA.

\section{. Irrigação}

As plantas foram irrigadas através de um sistema de gotejamento que funcionava de forma intermitente, sendo acionado eletricamente por um 
temporizador, regulado para atender o tempo de irrigação necessitado pelas plantas.

\subsubsection{Variáveis analisadas}

\section{- Produção de matéria seca}

Após setenta dias do plantio das mudas, quando as plantas apresentavam brotações com aproximadamente $1,50 \mathrm{~m}$ de comprimento, foi realizada a poda do sistema aéreo. Os ramos coletados foram colocados em estufa à $65^{\circ} \mathrm{C}$ por 72 horas, e a seguir foram pesados para determinação da produção de matéria seca de cada cultivar.

\section{- Quantidade acumulada de macronutrientes}

As amostras, que tinham sido previamente preparadas através de secagem e posterior moagem do material seco, foram analisadas conforme metodologia descrita em Sarruge e Haag (1974), para determinação do teor e quantidade total de macronutrientes acumulados pelo sistema aéreo.

\subsubsection{Análise estatistica}

Os resultados obtidos foram submetidos à análise estatistica através do programa SAS, realizando-se a análise de variāncia e o teste Tukey, ao nivel de $5 \%$ de probabilidade, para as médias.

\subsection{Resultados e discussão}

\subsubsection{Produção de matéria seca}

A produção de matéria seca pelas diversas cultivares é utilizada como um indice de vigor, sendo este um reflexo do potencial genético de cada cultivar, seja ela porta-enxerto ou produtora, desde que estabelecidas sob as mesmas condições edafoclimáticas. Entretanto pode-se alterar o vigor de uma cultivar produtora pela utilização de um porta-enxerto mais ou menos vigoroso. Outro aspecto a considerar é que a produção de matéria seca pelas 
plantas é resultante de processos fisiológicos integrados, principalmente da taxa fotossintética líquida.

O vigor dos porta-enxertos confirmou-se através da produção de matéria seca (Figura 27), salientando-se o 'Jales' (IAC 572) com uma massa por planta de 45,036g, vindo a seguir o porta-enxerto 'Tropical' (IAC 313). Os portaenxertos de origem americana: 'Harmony', 'Salt Creek' e 'Dog Ridge' apresentaram um desenvolvimento vegetativo mais lento, com menor produção de matéria seca e as produtoras 'Italia' e 'Thompson' foram semelhantes a estes ültimos na velocidade de crescimento do sistema aéreo, com um vigor mediano. Aimone e Bovio (1988) obtiveram um rápido desenvolvimento das videiras e uma precoce produção de uvas com os porta-enxertos '125AA' e 'Kober 5BB', considerados vigorosos; no entanto as videiras no 'Paulsen 1103' e no 'Rupestris du Lot', porta-enxertos de vigor mediano, demonstraram um equilibrio entre o crescimento vegetativo e o peso e a qualidade dos cachos.

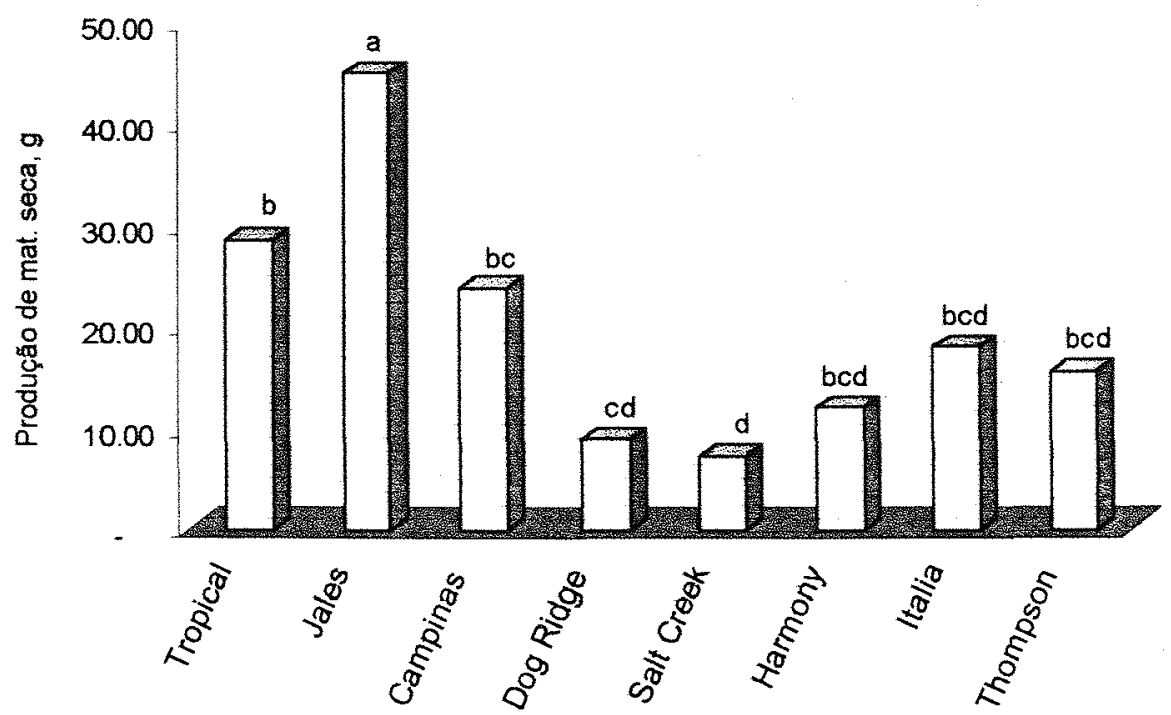

Figura 27. Produção de matéria seca da parte aérea de plantas de porta-enxerto e produtoras de videira. Colunas identificadas pelas mesmas letras não diferem entre si ao nivel de $5 \%$ pelo Teste de Tukey.

Terra et al. (1990) compararam o efeito de quatro cultivares IAC de uvas para vinho e concluiram que as maiores produções foram obtidas com 'Máximo' (IAC 138-22) e 'Sanches' (IAC 960-9) sobre o porta-enxerto 'Tropical', no entanto a cultivar 'Rainha' (IAC 116-31), sobre o mesmo porta-enxerto, apresentou grande vigor vegetativo com baixas produçōes. Keller e Koblet 
(1995) trabalhando com luminosidade e doses de $\mathrm{N}$ na cv. Müller-Thurgau sobre o porta-enxerto $\mathrm{SO} 4$, relataram que em condições de moderada luminosidade e aporte elevado de $\mathrm{N}$, a alocação de carbohidratos e nutrientes é direcionada para o crescimento vegetativo anual em detrimento das partes reprodutivas e perenes das plantas. Nessas condições as plantas mostram-se vigorosas e com uma vegetação exuberante, que, contraditoriamente, induz a um deficiente crescimento das raizes, o qual só é possivel se houver um excedente de fotoassimilados nos ramos (Araujo e Williams, 1988).

\subsubsection{Quantidade acumulada de macronutrientes}

Quanto a capacidade de acumular nutrientes, os resultados obtidos demostram haver uma real diferença entre os diversos porta-enxertos e entre estes e as produtoras (Figura 28). O porta-enxerto Jales foi o que extraiu maior quantidade de nutrientes da solução nutritiva, sendo superior aos demais na extração de N, P, K e Ca, igualando-se ao Tropical na extração de Mg; estes dados revelam sua maior exigência nutricional e capacidade de produção de biomassa. A extração de $\mathrm{N}, \mathrm{K}$ e Mg do porta-enxerto 'Campinas' (IAC 766) foi semelhante à apresentada pelo mesmo porta-enxerto em trabalho realizado em solo por Pereira et al. (1976) onde foram compara dos cinco porta-enxertos.

A extração de nutrientes pelas cultivares produtoras 'Italia' e 'Thompson' foi semelhante aos porta-enxertos de vigor mediano ('Tropical' e 'Campinas') e de pouco vigor ('Dog Ridge', 'Salt Creek' e 'Harmony'), apresentando valores quantitativos intermediários. Este fato pode servir como indicação da resposta em vigor e em produtividade que uma produtora apresentará quando enxertada sobre porta-enxertos com diferentes capacidade de produção de massa verde. Freire et al. (1991) observaram, em trabalho realizado sob condições de clima tropical, no Nordeste do Brasil, que a cultivar Thompson enxertada sobre Tropical' teve uma produção de $5,66 \mathrm{~kg}$ por planta e que a produção aumentava a medida que o vigor do porta-enxerto utilizado diminuia, sendo a produção da cultivar sobre o porta-enxerto 'Harmony' de $14,54 \mathrm{~kg}$, o que representa um aumento de $157 \%$ em relação as plantas enxertadas no 'Tropical'. Outro aspecto a ser considerado é o fato de que as plantas de pé- 
franco apresentaram uma produção intermediária, denotando haver uma relação inversamente proporcional entre a capacidade de extração de nutrientes e a produção de cachos na cultivar Thompson. Muthukrishnan e Srinivasan (1974) em estudo realizado sobre o estado nutricional de trinta vinhedos sob condições de clima tropical, encontraram correlação negativa entre teor de nitrogênio nos pecíolos e fertilidade das gemas e correlação positiva entre teor de fósforo e peso dos cachos. Existem também evidências de que as reservas em $\mathrm{N}$ dos sarmentos é que são utilizadas para o desenvolvimento dos ramos, mais do que o $\mathrm{N}$ adicionado durante esta fase de crescimento. Baldwin (1966) trabalhando com 'Thompson Seedless' constatou que teores baixos de $\mathrm{N}$, altos de $\mathrm{P}$ e estresse hídrico são fatores associados com a alta fertilidade das gemas. Christensen (1975) em trabalho realizado na Califórnia, obteve um marcante aumento na fertilidade das gemas latentes em vinhedos da 'Thompson Seedless' com aplicações de quantidades maiores de potássio no solo.

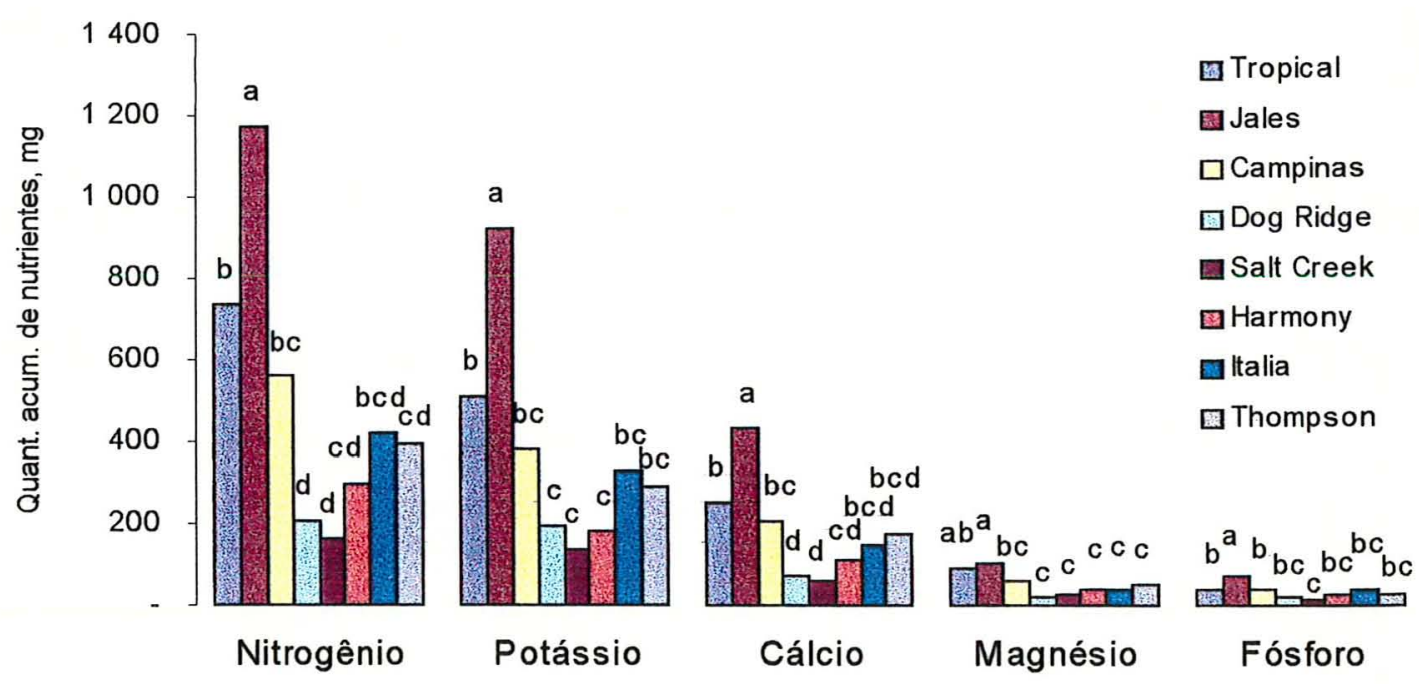

Figura 28. Quantidade acumulada de macronutrientes da parte aérea de plantas de porta-enxerto e produtoras de videira. Colunas identificadas pelas mesmas letras não diferem entre si ao nivel de $5 \%$ pelo Teste de Tukey.

Iannini (1984) comenta que o porta-enxerto influencia as videiras enxertadas, em especial, na absorção do potássio e do magnésio. Ruhl (1989) relata que os porta-enxertos 'Freedom', 'Dog Ridge' e 'Rupestris du Lot' 
contribuiram para um $\mathrm{pH}$ mais elevado no suco das uvas das plantas enxertadas, e estas mostraram alta concentração de $\mathrm{K}^{+}$nos peciolos, enquanto que os porta-enxertos '140Ru', '1202C' e '110R' causaram resultados contrários, o que também foi constatado por Brancadoro et al. (1995) na cultivar Croatina, que apresentou os mais baixos niveis de $K^{+}$nas folhas quando utilizados os porta-enxertos '140 Ru', '420A' e '1202C'.

Neste trabalho tanto os porta-enxertos como as produtoras apresentaram teores adequados de nutrientes, por ser a solução nutritiva balanceada para que não ocorressem excessos e nem deficièncias. A fotossintese realizada pelas folhas, por ser um processo complexo, envolvendo diversos compostos, é influenciada de modo significativo pelos elementos essenciais à vida das plantas. Williams e Smith (1985) obtiveram uma correlação linear entre a taxa liquida de assimilação de $\mathrm{CO}_{2}$ e a concentração de $\mathrm{N}$ nas folhas de videiras. Sabendo-se que a maior quantidade do $\mathrm{N}$ nas folhas está na forma de proteinas e sendo a Ribulose 1,5-bisfosfato carboxilase / oxigenase (RuBPC/O ou Rubisco) a mais abundante delas e a de maior importância na regulação do ciclo PCR (Millard, 1995), pode-se inferir sobre a importāncia do $\mathrm{N}$ no processo fotossintético. Outro nutriente mineral que pode afetar a capacidade das folhas em fixar $\mathrm{CO}_{2}$ é o $\mathrm{P}$, por ser o principal componente da adenosina trifosfato (ATP), envolvida nos processos de transferência de energia na maior parte dos ciclos bioquímicos das plantas.

\subsection{Conclusões}

A realização deste experimento permitiu concluir que:

- as cultivares Jales e Tropical são os mais vigorosos porta enxertos entre os testados;

- a quantidade de nutrientes acumulados é proporcional a produção de biomassa;

- a produção de biomassa das produtoras Thompson Seedless e Italia mostra-se inferior ao do porta-enxerto Jales; 
- as cultivares Thompson Seedless e Italia apresentam capacidade de absorção de nutrientes semelhante aos dos porta-enxertos de baixo e médio vigor. 


\section{CONSIDERAÇÕES FINAIS}

Os anos de pesquisa com videiras na regiāo do trópico semi-árido do Brasil nos leva a questionar:

- Por que videiras de uma mesma espécie, como a Italia e a Thompson Seedless, têm respostas tão diferentes a um mesmo sistema de produção, sendo que esta última não atinge um desenvolvimento de paniculas florais semelhante as outras cultivares?

- Por que os ramos da cultivar Italia, mesmo sob condições de irrigação continua, durante a fase de maturação dos bagos, reduzem a taxa de crescimento até pararem totalmente, permanecendo assim por 20-25 dias após a colheita e os da Thompson Seedless não apresentam supressão do crescimento, atingindo até dez metros de comprimento?

- Por que a Thompson Seedless apresenta ramos tão vigorosos e com folhas grandes e de coloração verde claro, enquanto que na Califórnia as plantas desta cultivar são de mediano vigor e possuem folhas verdes escuras?

Através de extensa revisão de literatura sobre o assunto, verificou-se a estreita relação existente entre os fitohormônios, a nutrição mineral e a sintese e translocação de fotoassimilados. E pode-se, então, fazer as seguintes inferèncias:

- O balanço hormonal citocininas/giberelinas desencadearia a formação de gavinhas ou flores nas videiras, estando diretamente relacionado ao florescimento.

- As citocininas estão também associadas com a partição de assimilados.

- A biossintese de citocininas é realizada preferencialmente nos meristemas radiculares, e as raizes das plantas necessitam dos fotoassimilados elaborados no sistema aéreo para que possam crescer, assim como sintetizar citocininas. 
- A translocação dos metabólitos só acontece após a colheita, porque os frutos são os drenos preferenciais na fase de produção.

- Se o sistema aéreo não pára de se expandir, as raízes não armazenam substâncias de reserva suficientes para seu próprio crescimento e para a formação de citocininas, rompendo então o equilíbrio entre citocininas e giberelinas, o que conduz ao excessivo vigor e deficiente floração das plantas.

Com base nos conceitos acima colocados, testou-se, nesta pesquisa, a hipótese de que a redução do vigor vegetativo através de retardadores de crescimento, poderia alterar os teores e quantidades acumuladas de macronutrientes nas cultivares de videira Thompson Seedless e Italia, e deste modo favorecer o acúmulo de metabólitos no sistema radicular; assim como, a comparação de porta-enxertos com as produtoras, na capacidade de absorver macronutrientes, de modo a obter-se um porta-enxerto que absorva quantidades minimas suficientes para reduzir o vigor da produtora enxertada sobre ele.

As pesquisas foram realizadas em casa-de-vegetação, pelo fato de que nesse ambiente as plantas teriam desenvolvimento semelhante ao apresentado no nordeste, com o crescimento continuo das videiras da cultivar Thompson Seedless, não havendo periodo de repouso. Este fato é de relevante importância para que os resultados aqui obtidos possam ser inicialmente extrapolados para aquela região, merecendo, porém, um estudo mais detalhado em condiçōes de campo. 


\section{CONCLUSÕES FINAIS}

A realização dos experimentos propostos nesta pesquisa possibilitou testarem-se as hipóteses de forma satisfatória, permitindo concluir que as práticas culturais empregadas poderão fazer parte de um sistema de produção para a cultivar Thompson Seedless. Os resultados aqui obtidos deverão ser testados com mais sutilezas de detalhes, levando a respostas mais conclusivas com relação ao retardador a ser utilizado e à dose mais adequada, assim como analisar a interação dos porta-enxertos Harmony, Salt Creek e Dog Ridge enxertados com a cultivar Thompson Seedless, no que diz respeito a absorção de nutrientes, formação e armazenamento de fotoassimilados e biossintese de metabólitos e hormônios. 


\section{REFERÊNCLAS BIBLIOGRÁFICAS}

ABOTT, D.L. A tree physiologist's view of growth regulators. Acta Horticulturae, v.179, p.293-301, 1986.

AIMONE, S.; BOVIO,M. Comparative trial on six Barbera rootstock combinations in the Basso Wonteroto district. Results on the first years of observation. Annali della Facoltà di Scienze Agrarie della Universitá degli Studi di Torino, v.14, p.63-76, 1988.

ANUÁRIO ESTATÍSTICO DO BRASIL - 1995. Rio de Janeiro, v.56, 1996.

ARAUJO, F.J.; WILLIAMS, L.E. Dry matter and partitioning and root growth of young field-grown Thompson Seedless grapevines. Vitis, v.27, p.21-32, 1988.

BALDWIN, J.G. The relation between weather and fruitfulness of Sultana vine. Australian Journal of Agricultural Research, v.15, p.920-928, 1964.

BALDWIN, J.G. The effect of some cultural practices on nitrogen and fruitfulness -in the Sultana vine. American Journal of Enology and Viticulture, v.17, p.58-62, 1966.

BRANCADORO, L.; VALENTI, L.; REINA, A. Rootstock effect on potassium content of grapevine. Acta Hortculturae, n.383, p.115-124, 1995.

BUTTROSE, M.S. Fruitfulness in grapevines: the response of different cultivars to light, temperature and day length. Vitis, v.9, p.121-125, 1970.

BUTTROSE, M.S. Climatic factors and fruitfulness in grapevines. Horticultural Abstracts, v.44, p.319-325, 1974.

CASUCCI, M. Uva da tavola, il futuro e apirene. Vignevini, n.4, p.21-22, 1995. 
CHAILAKHYAN, M. Hormonal regulation of plant flowering. In: PILET, P.E. (Ed.) Plant growth regulation. Berlin: Springer-Verlag, 1977. p.258-272..

CHRISTHENSEN, P. Long-term responses of Thompson Seedless vines to Kfertilizer treatment. American Journal of Enology and Viticulture, v.26, p.179-183, 1975.

COOMBE, B.G. Effect of growth retardants on Vitis vinifera. Vitis, v.6, p.278$287,1967$.

COOMBE, B.G. Fruit set in grape vines: the mechanism of the CCC effect. Journal of Horticultural Science, v.45, p.415-425, 1970.

CONRADIE, W.J. Seasonal uptake of nutrients by Chenin Blanc in sand culture: II. Phosphorus, calcium and magnesium. South African Journal of Enology and Viticulture, v.2, n.1, p.7-13, 1981.

CONRADIE, W.J. Distribuition and translocation of nitrogen absorbed during late spring by two-year-old grapevines grown in sand culture. American Journal of Enology and Viticulture, v.41, n.3, p.241-250, 1990.

FREIRE, L.; ALBUQUERQUE, J.A.S. de; ALBUQUERQUE, T.C.S. de. Comportamento da cultivar de uva Thompson Seedless sobre diferentes porta-enxertos na regiāo do submédio São Francisco. In: CONGRESSO BRASILEIRO DE FRUTICULTURA, 11., Petrolina, 1991. Revista Brasileira de Fruticultura, Cruz das Almas, v.13, n.2, p. 129-133, out.1991.

FURLANI, P.R. Cultivo de alface pela técnica de hidroponia - NFT. Campinas: Instituto Agronômico, 1995. 18p. (IAC. Documentos, 55).

HOGLAND, D.R.; ARNON, D.I. The water culture method for growing plants without soil. Berkeley: The College of Agriculture, 1950. 32p. (Circular, $347)$.

IANNINI, B. Importanza e funzioni del portinnesto nella viticoltura moderna. Rivista di Viticoltura e di Enologia, n.7-8, p.394-419, 1984. 
IONESCU, P. Influence de substances regulatrices de la croissance sur le processus de photosynthese et de respiration de la vigne. In: SYMPOSIUM INTERNATIONAL SUR LA PHYSIOLOGIE DE LA VIGNE, 3., Bordeaux, 1986. Annales. Paris: Office International de la Vigne et du Vin., 1987. p.142-147.

JAUMIEN, F.; WIKTOROWICZ, M.; OSIŃSKA, B. Vegetative growth control and fruiting of young pear trees treated with CCC, SADH PP333 (paclobutrazol) and a mixture of these compounds with CEPA. Acta Horticulturae, v.179, p.221-228, 1986.

JONES Jr., J.B. A guide for the hydroponic and soiless culture grower. Portland: Timber Press, 1983. 124p.

KARASZEWSKA, A.; JANKOWSKA, B.; MIKA, M.; GROCHOWSKA, M.J. Effects of growth regulator treatments on the hormone pattern in the trunk and the collar tissue of apple trees. Acta Horticulturae, v.179, p.185-194, 1986.

KERBY, T.A. Cotton response to mepiquat chloride. Agronomy Journal, v.77, p.515-518, 1985.

KELLER, M.; KOBLET, W. Dry matter and leaf area partitioning, bud fertility and second season growth of Vitis vinifera L. : Responses to nitrogen supply and limiting irradiance. Vitis, v.34, n.2, p.77-83, 1995.

KLIEWER, W.M. Grapevine physiology: how does a grapevine make sugar?. Berkeley: USDA; University of California, Cooperative Extension. 1981. $13 p$.

KLIEWER, W.M. Influence of nitrogen fertilization and trellis training systems on nutritional status, crop yield and fruit composition of Thompson Seedless grape vines grow in California. In: UNIVERSITY OF CALIFORNIA. Departmental report. Davis, 1989-1990. p.71.

KLIEWER,W.M.; BLEDSOE, A.M. Influence of hedging and leaf removal on canopy microclimate, grape composition, and wine quality under California conditions. Acta Horticulturae, v.206, p.157-168, 1987. 
LAVEE, S.; EREZ, A.; SHULMAN, Y. Control of vegetative growth of grape vines (Vitis vinifera) with chloroethylphosphonic acid (Ethephon) and other growth inhibitors. Vitis, v.16, p.89-96, 1977.

LILOV, D.; ANDANOVA, T. Cytokinins,growth, flower and fruit formation in Vitis vinifera. Vitis, v.15, p.160-170, 1976.

MAY, P.; CLINGELIFFER, P.R.; BRIEN, C.J. Sultana (Vitis vinifera L.) canes and their exposure to light. Vitis, v.14, p.278-288, 1976.

MAY, P.; SHAULIS, N.J.; ANTCLIFF, A.J. The effect of controlled defoliation in the Sultana vine. American Journal of Enology and Viticulture, v.20, p.237-250, 1969.

MILLARD, P. Internal cycling of nitrogen in trees. Acta Horticulturae, v.383, p.3-13, 1995.

MOTOMURA, Y. Effects of gibberellin and daminozide on the distribution of ${ }^{14} \mathrm{C}$-assimilates in grape shoots. Acta Horticulturae, v.1, n.179, p.421424, 1986.

MULLINS, M.G. Hormonal regulation of flowering and fruit set in the grapevine. Acta Horticulturae, v.179, p.309-315, 1986.

MULLINS, M.G.; BOUQUET, A.; WILLIAMS, L.E. Biology of grapevine. Cambridge: Cambridge University Press, 1992. 239p.

MUTHUKRISHNAN, C.R.; SRINIVASAN, C. Correlation between yield quality and petiole nutrients in grapes. Vitis, v.12, p.277-285, 1974.

NITSCH, J.P.; NITSCH, C. Présence de phytokinines et autres substances de croissance dans la sève d' Acer saccharum et de Vitis vinifera. Bulletin de la Societé Botanique Française, v.112, p.11-12, 1965.

PEACOCK, W.L.; CHRISTHENSEN, L.P.; BROADBENT; F.E. Uptake, storage, and utilization of soil-applied nitrogen by Thompson Seedless as affected by time of application. American Journal of Enology and Viticulture, v.40, n.1, p.16-20, 1989 . 
PEREIRA, F.M.; KOSHIDA, H. Resposta do cultivar de videira IAC 21-14 ao fitormōnio cycocel 500A. In: CONGRESSO BRASILEIRO DE FRUTICULTURA, 2., Viçosa, 1973. Anais. Viçosa: SBF, 1973. v.2, p. 529-536.

PEREIRA, F.M.; HIROCE, R.; IGUE, T.; OLIVEIRA, J.C. de. Pegamento, desenvolvimento e extração de macronutrientes de cinco porta-enxertos de videira. Bragantia, v.35, p.47-54, 1976.

POMMER, C.V. Uva. In: FURLANI, A.M.C.; VIÉGAS, G.P. (eds.) o melhoramento de plantas no Instituto Agronômico. Campinas: Instituto Agronômico, 1993. v.1, p.489-524.

POUGET, R. Action de la concentration de la solution nutritive sur quelques caractéristiques physiologiques et technologiques chez Vitis vinifera L. cv. Cabernet Sauvignon. I. - Viguer, rendement, qualité du moūt et du vin. Agronomie, v.4, n.5, p.437-442, 1984.

RAI, N.; BIST, L.D. Effectes of promalin, SADH and chlormequat on tree growth, flowering, fruit-set, yield and fruit quality of 'Gola' pear. Journal of Horticultural Science, v.66, n.4, p.443-447, 1991.

RIVES, M. L'initiation florale chez la vigne. Connaissance de la Vigne et du Vin, v.2, p.127-146, 1972 .

RUHL, E.H. Uptake and distribution of potassium by grapevine rootstocks and its implication for grape juice $\mathrm{pH}$ of scion varieties. Australian Journal of Experimental Agriculture, v.29, n.5, p.707-712, 1989.

SACHS, R.M. Nutrient diversion: An hypothesis to explain the chemical control of flowering. Horticultural Science, v.12, p.220-222, 1977.

SACHS, R.M.; HACKETT, W.P. Chemical control of flowering. Acta Horticulturae, v.68, p.29-49, 1976.

SARRUGE, J.R.; HAAG, H.P. Análises químicas em plantas. Piracicaba: ESALQ, Departamento de Quimica, 1974. 54p. 
SKENE, K.G.M. The relationship between the effects of CCC on root growth and cytokinin levels in the bleeding sap of Vitis vinifera L. Journal of Experimental Botany, v.21, p.418-431, 1970.

SKENE, K.G.M.; KERRIDGE, G.H. Effect of root temperature on cytokinin activity in root exudate of Vitis vinifera L. Plant Physiology, v.42, p.1131$1139,1967$.

SKINNER, P.W.; MATTHEWS, M.A. Reproductive development in grape (Vitis vinifera L.) under phosphorus-limited conditions. Scientia Horticulturae, v.38, p.49-60, 1989.

SMART, R. E. Principles of grapevine canopy microclimate manipulation with implications for yield and quality. A review. American Journal of Enology and Viticulture v.36, p.230-239, 1985.

SOUSA, J.S.I.de. Uvas para o Brasil. 2.ed. Piracicaba: Fundação Escola de Agronomia Luiz de Queiroz, 1996. 791p.

SRINIVASAN, C.; MULLINS, M.G. Effects of temperature and growth regulators on formation of Anlagen, tendrils and inflorescence in vitis vinifera L. Annals of Botany, v.45, p.436-446, 1980.

SRINIVASAN, C.; MULLINS, M.G. Physiology of flowering in the grapevine - a review. American Journal of Enology and Viticulture, v.32, p.47-63, 1981.

TERRA, M.M.; PIRES, E.J.P.; PETTINELLI Jr., A. et al. Produtividade de cultivares IAC de uvas para vinho como produtores diretos e sobre diferentes porta-enxertos. Bragantia, v.49, n.2, p.345-362, 1990.

VAN STADEN, J.; COOK, E.L. Citokinins and fruit production. Acta Horticulturae, v.179, p.73-81, 1986.

WILLIAMS, L.E. Growth of 'Thompson Seedless' grapevines: II. Nitrogen distribution. Journal of the American Society for Horticultural Science, v.112, p.330-333, 1987 . 
WILLIAMS, L.E.; BISCAY, P.J.; SMITH, R.J. Effect of interior canopy defoliation on berry composition and potassium distribution in Thompson Seedless grapevines. American Journal of Enology and Viticulture, v.38, p.287-292, 1987.

WILLIAMS, L.E.; SMITH, R.J. Net $\mathrm{CO}_{2}$ assimilation rate and nitrogen content of grape leaves subsequent to fruit harvest. Journal of the American Society for Horticultural Science, v.110, p.846-850, 1985.

ZIMMERMANN, J. Wein weg der unterlogenzüchtung aut affinität und adaptation. Bulletin Office International de la Vigne et du Vin, v.59, n.665-666, p.923, 1986. 